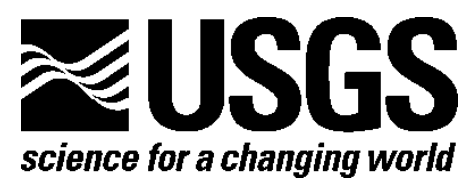

\title{
Preliminary Interpretation of Industry Two-Dimensional Seismic Data from Susitna Basin, South-Central Alaska
}

Kristen A. Lewis, Christopher J. Potter, Anjana K. Shah, Richard G. Stanley, Peter J. Haeussler, and Richard W. Saltus

Open-File Report 2015-1138

U.S. Department of the Interior

U.S. Geological Survey 


\section{U.S. Department of the Interior \\ SALLY JEWELL, Secretary}

\section{U.S. Geological Survey \\ Suzette M. Kimball, Acting Director}

U.S. Geological Survey, Reston, Virginia: 2015

For more information on the USGS - the Federal source for science about the Earth, its natural and living resources, natural hazards, and the environment-visit http://www.usgs.gov or call 1-888-ASK-USGS

For an overview of USGS information products, including maps, imagery, and publications, visit http://www.usgs.gov/pubprod

To order this and other USGS information products, visit http://store.usgs.gov

Suggested citation:

Lewis, K.A., Potter, C.J., Shah, A.K., Stanley, R.G., Haeussler, P.J., and Saltus, R.W., 2015, Preliminary interpretation of industry two-dimensional seismic data from Susitna Basin, south-central Alaska: U.S. Geological Survey Open-File Report 2015-1138, 51 p., http://dx.doi.org/10.3133/ofr20151138.

ISSN 2331-1258 (online)

Any use of trade, firm, or product names is for descriptive purposes only and does not imply endorsement by the U.S. Government.

Although this information product, for the most part, is in the public domain, it also may contain copyrighted materials as noted in the text. Permission to reproduce copyrighted items must be secured from the copyright owner. 


\section{Contents}

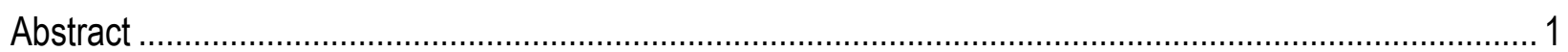

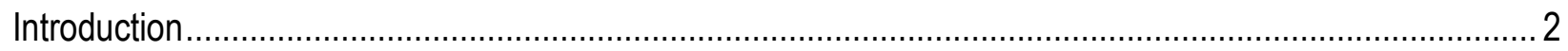

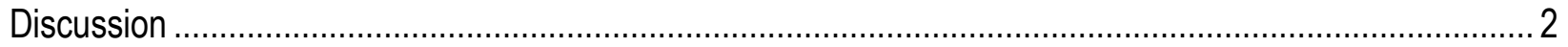

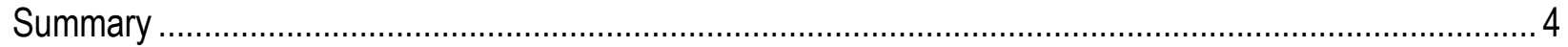

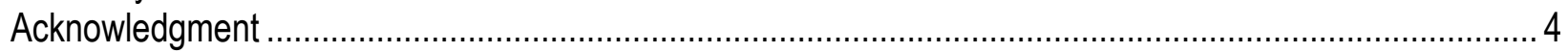

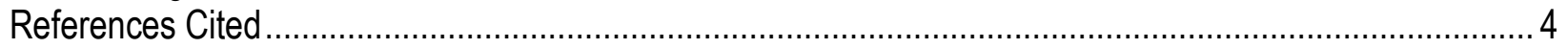

Figures

\section{Figures}

Figure 1. Map of Alaska showing the location of the study area (Susitna Basin) ................................... 6

Figure 2. Map of Susitna Basin including the seven exploratory wells ................................................

Figure 3. Fault map of the Susitna Basin seismic coverage area …................................................. 8

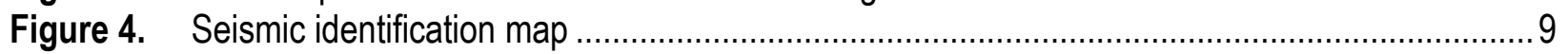

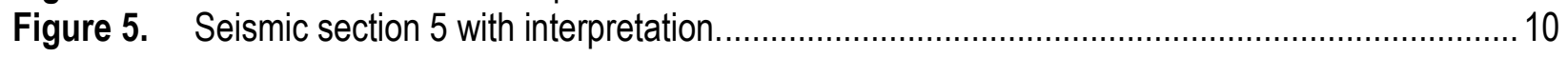

Figure 6. Seismic section 6 with interpretation....................................................................... 10

Figure 7. Seismic section 7 with interpretation....................................................................... 11

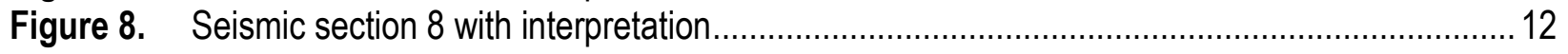

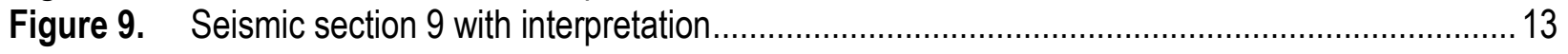

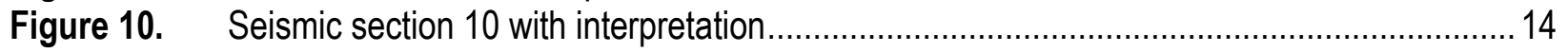

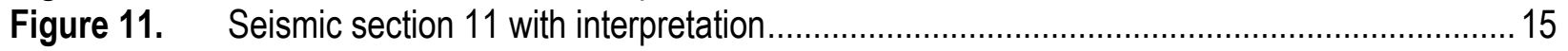

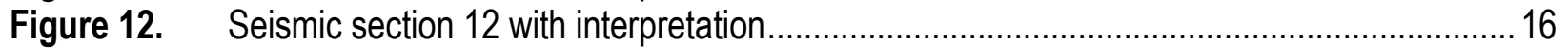

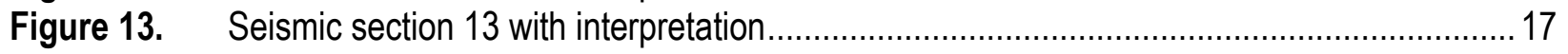

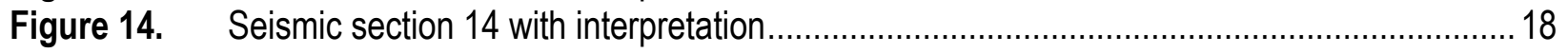

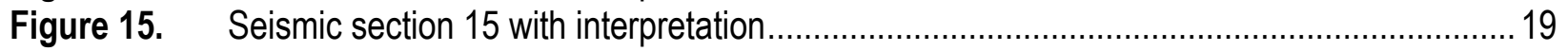

Figure 16. Seismic section 16 with interpretation....................................................................... 20

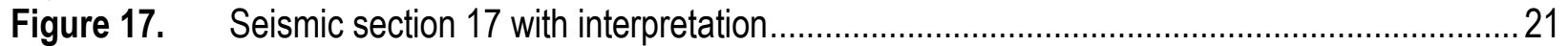

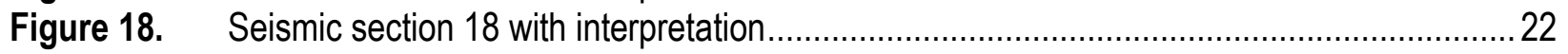

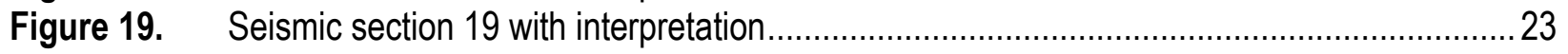

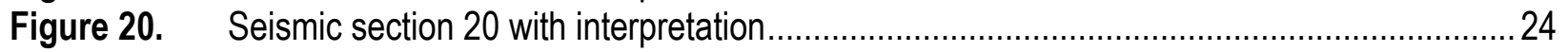

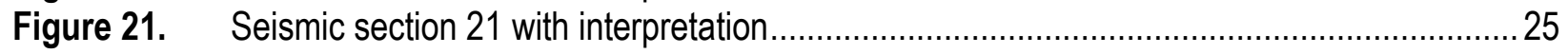

Figure 22. Seismic section 22 with interpretation...................................................................26

Figure 23. Seismic section 23 with interpretation................................................................... 27

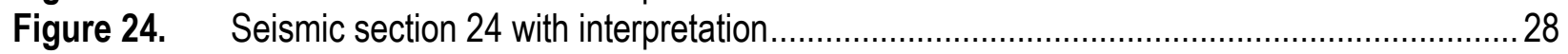

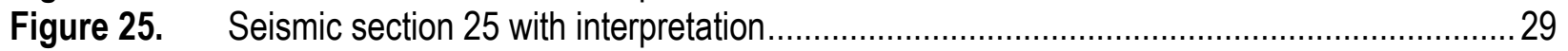

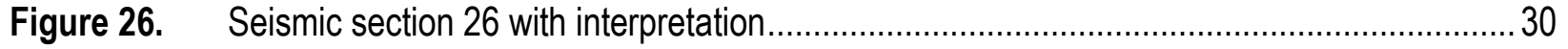

Figure 27. Seismic section 27 with interpretation..................................................................... 31

Figure 28. Seismic section 28 with interpretation..................................................................... 32

Figure 29. Seismic section 29 with interpretation................................................................. 33

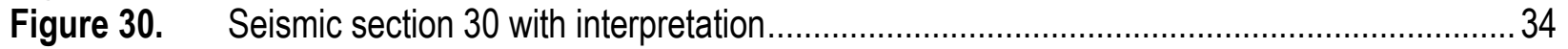

Figure 31. Seismic section 31 with interpretation ..................................................................... 35

Figure 32. Seismic section 32 with interpretation..................................................................... 36

Figure 33. Seismic section 33 with interpretation................................................................... 37

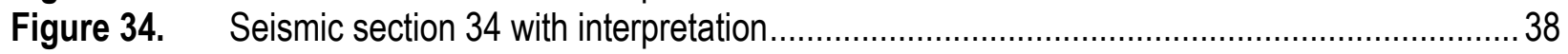

Figure 35. Seismic section 35 with interpretation..................................................................... 39 
Figure 36. Seismic section 36 with interpretation................................................................... 40

Figure 37. Seismic section 37 with interpretation................................................................ 41

Figure 38. Seismic section 38 with interpretation............................................................... 42

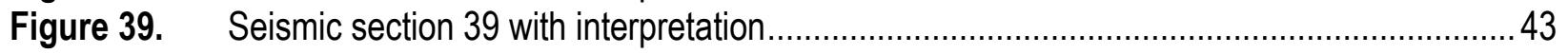

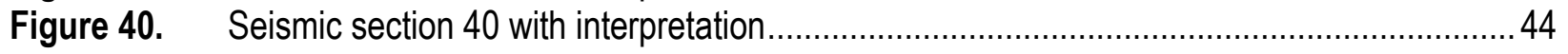

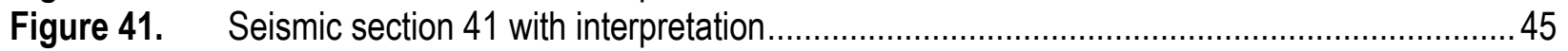

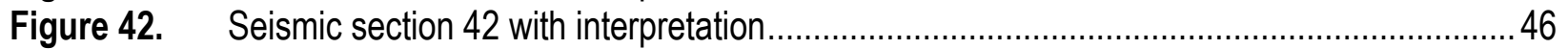

Figure 43. Seismic section 43 with interpretation.................................................................... 47

Figure 44. Seismic section 44 with interpretation..................................................................... 48

Figure 45. Seismic section 45 with interpretation................................................................... 49

Figure 46. Map showing the filtered aeromagnetic data within the seismic data coverage area...........50

Figure 47. Well correlation of the Trail Ridge Unit 1, Pure Kahiltna Unit 1, and Sheep Creek 1 exploratory wells. 


\title{
Preliminary Interpretation of Industry Two-Dimensional Seismic Data from Susitna Basin, South-Central Alaska
}

Kristen A. Lewis ${ }^{1}$, Christopher J. Potter ${ }^{2}$, Anjana K. Shah¹, Richard G. Stanley ${ }^{3}$, Peter J. Haeussler ${ }^{4}$, and Richard W. Saltus ${ }^{1}$

\begin{abstract}
Located approximately 80 kilometers northwest of Anchorage, Alaska, the Susitna Basin is a complex sedimentary basin whose tectonic history has been poorly understood. Recent interpretation of two-dimensional seismic reflection data integrated with well, aeromagnetic, and gravity data provides new insights into the structural and stratigraphic nature of the basin.

This report presents an interpretation of 41 two-dimensional seismic reflection lines, acquired by industry from the 1960s to the 1980s. Our interpretation of the seismic data focused mainly on picking two Eocene stratigraphic units and a presumed base of Tertiary horizon. Based on our interpretation of the seismic data, the structural features in the basin appear to be generally contractional, as evidenced by the presence of many reverse faults, thrust faults, and folds, with the contraction mainly oriented east-west. This result is contrary to prior inferences of most previous geologic studies that showed normal faults. Several regional reverse faults have been identified in the seismic data and appear to divide the basin into three regions or "sides": east, west, and south.

The eastern seismic lines show evidence of numerous short-wavelength antiforms that appear to correspond to a series of northeast-trending lineations observed in aeromagnetic data, which have been interpreted as being due to folding of Paleogene volcanic strata. The eastern side of the basin is also cut by a number of reverse faults and thrust faults, the majority of which strike north-south. The western side of the Susitna Basin is cut by a series of regional reverse faults and is characterized by synformal structures in two fault blocks between the Kahiltna River and Skwentna faults. These synforms are progressively deeper to the west in the footwalls of the east-vergent Skwentna and northeast-vergent Beluga Mountain reverse faults. Although the seismic data are limited to the south, we interpret a potential regional south-southeastdirected reverse fault striking east-northeast on the east side of the basin that may cross the entire southern portion of the basin.
\end{abstract}

\footnotetext{
${ }^{1}$ U.S. Geological Survey, Denver, Colorado

${ }^{2}$ U.S. Geological Survey, Piscataway, New Jersey

${ }^{3}$ U.S. Geological Survey, Menlo Park, California

${ }^{4}$ U.S. Geological Survey, Anchorage, Alaska
} 


\section{Introduction}

Susitna Basin is a complex sedimentary basin located in south-central Alaska, approximately 80 kilometers $(\mathrm{km})$ northwest of Anchorage (fig. 1). Situated just north of Cook Inlet, the Susitna Basin is bounded to the north by the central Alaska Range, to the east by the Talkeetna Mountains, to the west by the western Alaska Range including the Tordrillo Mountains, and to the south by the Castle Mountain fault, which separates it from the hydrocarbon-rich Cook Inlet Basin (CIB) (fig. 2).

Although the Susitna Basin is proximal to the well-studied CIB, its tectonic history is poorly understood and its possible relationship to the CIB has not been well established. Different models have been proposed through the years to depict the structural history of the basin. For instance, Kirschner $(1988,1994)$ indicated that the Susitna Basin is bounded entirely by normal faults. Hackett's $(1976,1977)$ interpretation of gravity data, on the other hand, indicated a reverse fault (the Beluga Mountain fault) bounding the basin to the southwest (fig. 3). Gillis and others (2013) suggested that the Beluga Mountain fault might control accommodation of sediment in the Susitna Basin. Sediment accommodation might also be influenced by other significant faults hidden in the subsurface. Determining the structural style and geometry of all of these faults is important to understanding the depositional history and hydrocarbon potential of the basin.

Through the interpretation of industry-provided two-dimensional seismic reflection data integrated with exploratory well, aeromagnetic, and gravity data, this report presents new insights into the structural and stratigraphic nature of Susitna Basin. The interpretation and information provided in this report are part of an ongoing investigation of the basin as part of the U.S. Geological Survey (USGS) Alaska Petroleum Systems project.

\section{Discussion}

The USGS was granted access to 43 proprietary, industry-acquired two-dimensional seismic reflection lines. These seismic lines, acquired from the early 1960s through the 1980s, form the basis for this study. The seismic lines total $685 \mathrm{~km}$ in length and extend over an area of approximately 2,750 square kilometers $\left(\mathrm{km}^{2}\right)$ in the Susitna Basin, with 15 seismic lines located on the west side of the basin, 27 on the east side, and one line spanning most of the basin from east to west (fig. 4).

In this publication, we present 41 of the industry-provided two-dimensional seismic lines with our interpretation (figs. 5-45). All the seismic lines are time sections with 3-5 seconds of data. No information regarding the acquisition or processing was provided by the data owner, so the seismic datum for all of the lines was assumed to be sea level. We include 41 of the 43 seismic lines because two of the lines were of such low signal quality as to be uninterpretable.

In addition to the industry-provided seismic data, we also used aeromagnetic data covering the Susitna Basin and the adjacent Tordrillo Mountains (U.S. Geological Survey, 2002, 2012). These surveys were flown with a nominal draped flight height of 1,000 feet (ft) above the ground with 1-mile (mi) spacing southwest of the Beluga Mountain fault and 1/2-mi spacing over the rest of the basin. High-pass filters were applied to flight line data (fig. 46) in order to enhance anomalies that are likely due to magnetic sources within the upper few kilometers of the basin (Shah and others, 2014).

From 1964 through 2005, seven exploratory wells were drilled in the basin with no commercially viable oil or gas discoveries reported. Of the seven exploratory wells, two wells 
are located within the seismic data coverage area: the Pure Kahiltna Unit 1 and Trail Ridge Unit 1 wells (fig. 4). Both of these wells terminated in Paleocene and lower Eocene volcanic and sedimentary rocks that are overlain by more than 1,200 meters of Eocene nonmarine sandstone, siltstone, and coal (Stanley and others, 2013, 2014). Miocene and Quaternary nonmarine strata, in turn, unconformably overlie the Eocene rocks (fig. 47).

Of the six Tertiary and Quaternary stratigraphic units identified in the Susitna Basin by Stanley and others $(2013,2014)$, the early Eocene unit E and early Eocene to late Paleocene unit F (fig. 47) are the only units that are present within the entire seismic coverage area. The tops of units $\mathrm{E}$ and $\mathrm{F}$, along with the inferred base of the Tertiary, were the main horizons of interest for this work. Because the base of the Tertiary sequence was not penetrated by any of the exploratory wells, the presumed base of the Tertiary horizon was picked based on changes in the seismic character observed on the two-dimensional sections, typically where the coherent seismic signal ended.

Compressional sonic logs were acquired in both the Pure Kahiltna Unit 1 and Trail Ridge Unit 1 wells, and, consequently, we generated P-wave synthetic seismograms for both wells. Although a density log was acquired for the Trail Ridge Unit 1 well, no density data exist for the Pure Kahiltna Unit 1 well, and we assumed a constant density of 2.65 grams per cubic centimeter for the computation. The wavelets used for computing the synthetic seismogram were extracted from the seismic sections located nearest to the well locations. The synthetic seismograms for these two wells were then tied to the nearest seismic lines, and the horizons of interest were identified.

Based on the interpretation of the two-dimensional seismic lines, the structural features of the Susitna Basin appear to be predominantly contractional, as evidenced by the presence of numerous reverse faults, thrust faults, and folds. This result is contrary to conclusions from several previous geologic studies (Kirschner, 1988, 1994; Trop and others, 2007). We identified several large, regional reverse faults in the seismic data, and they appear to divide the basin into three regions: east, west, and south (fig. 3).

The seismic lines from the eastern side of the Susitna Basin show evidence of numerous short-wavelength antiforms that appear to correspond approximately to a series of northeasttrending lineations observed in the filtered aeromagnetic data (fig. 46). These lineations may correspond to the axes of a series of folds located within volcanic strata in the Paleogene section (Shah and others, 2014). The Pure Kahiltna Unit 1 well penetrated one of the antiforms and encountered the tops of units $\mathrm{E}$ and $\mathrm{F}$ at depths of 1,004 ft and 4,216 ft TVDSS (true vertical depth subsea, or below mean sea level), respectively. The eastern side of the basin is also cut by a number of smaller reverse faults and thrust faults with the majority appearing to strike northsouth (fig. 3). The eastern side of the basin is separated from the west by a large regional reverse fault referred to as the Kahiltna River fault. Generally, the strata east of the Kahiltna River fault and approaching the Lockwood Lake fault to the south dip to the north as seen in seismic lines 5, 14, and 26 (figs. 5, 14, and 26).

The western side of the Susitna Basin is cut by a series of three regional reverse faults. These faults consist of one north-striking, west-vergent fault (Bulchitna Lake fault), one northstriking, east-vergent fault (Skwentna fault), and one northwest-striking, northeast-vergent fault (Beluga Mountain fault) (fig. 3). The Trail Ridge Unit 1 well was drilled into the structurally deepest fault block, bounded by the Skwentna and Bulchitna Lake faults, and penetrated the tops of units $\mathrm{E}$ and $\mathrm{F}$ at depths of 10,171 ft and 12,226 ft TVDSS, respectively, which is approximately 8,000 ft deeper than at the Pure Kahiltna Unit 1 well. To the west of this elongate 
synformal deep block, fault blocks step upward across the Skwentna and Beluga Mountain faults, and to the east, fault blocks step upward across the Bultchitna Lake and Kahiltna River faults (figs. 5, 7, 9, 33, and 34). Based on gravity data modeling, the Beluga Mountain fault is the southwestern boundary of the basin (Saltus and others, 2012, 2014).

Although the seismic coverage is sparse in the southern part of the Susitna Basin, we interpret a potential regional south-southeast-directed reverse fault (Lockwood Lake fault) striking east-northeast on the east side of the basin that may cut across the entire southern portion of the basin. Direct evidence of this fault is observed on three of the east-side seismic lines, sections 5, 12, and 14 (fig. 5, 12, and 14). On the west side of the basin, a magnetic anomaly lineament is on-strike with this fault (fig. 46) and corresponds to a stratigraphic offset observed between two non-intersecting seismic lines, lines 32 and 38 (figs. 32 and 38). The amount of vertical offset measured between these two seismic lines is roughly similar to that measured for the Lockwood Lake fault documented on the east-side seismic lines, suggesting that a fault potentially crosses between the two non-intersecting seismic lines (lines 32 and 38). We hypothesize that that presumed fault is the western continuation of the Lockwood Lake fault.

\section{Summary}

We have interpreted predominantly contractional structures (generally east-west contraction) in the Susitna Basin. This result is based on the interpretation of the 41 industry seismic sections provided in this publication, integrated with well, aeromagnetic, and gravity data and contradicts the conclusions from several previous geologic studies (Kirschner, 1988, 1994; Trop and others, 2007). Evidence of this contractional regime is indicated by the numerous short-wavelength antiforms, reverse faults, and thrust faults that are observed in the twodimensional seismic data and appear to be fundamental characteristics of the basin.

\section{Acknowledgment}

The authors would like to thank Chevron Corporation for providing the seismic data used in this study.

\section{References Cited}

Gillis, R.J., Stanley, R.G., LePain, D.L., Mauel, D.J., Herriott, T.M., Helmold, K.P., Peterson, C.S., Wartes, M.A., and Shellenbaum, D.P., 2013, Status of a reconnaissance field study of the Susitna Basin, 2011: Fairbanks, Alaska, Alaska Division of Geological and Geophysical Surveys, Preliminary interpretative report 2013-4, 12 p., accessed April 1, 2015 at http://pubs.dggsalaskagov.us/webpubs/dggs/pir/text/pir2013_004.pdf.

Hackett, S.W., 1976, Regional gravity survey of Beluga Basin and adjacent area, Cook Inlet region, southcentral Alaska: Fairbanks, Alaska, Alaska Division of Geological and Geophysical Surveys Alaska Open-File Report 100, 41 p.

Hackett, S.W., 1977, Gravity survey of Beluga Basin and adjacent area, Cook Inlet region, south-central Alaska: Fairbanks, Alaska, Alaska Division of Geological and Geophysical Surveys Geologic Report 49, 31 p., 3 sheets, scale 1:528,000.

Kirschner, C.E., 1988, Map showing sedimentary basins of onshore and continental shelf areas, Alaska: U.S. Geological Survey Miscellaneous Investigations Series Map 1873, 1 sheet, scale 1:2,500,000. 
Kirschner, C.E., 1994, Map showing sedimentary basins in Alaska (DNAG Alaska Volume G-1): Geological Society of America, 1 sheet, scale 1:2,500,000.

Saltus, R.W., Haeussler, P.J., Jones, J.V., III, Lewis, K.A., and Stanley, R.G., 2012, Gravity and magnetic investigation of Susitna Basin structure, Cook Inlet, Alaska: Geological Society of America, Abstracts with Programs, v. 44, no. 7, p. 76. [Annual Meeting, November 4-7, 2012, Charlotte, N.C.]

Saltus, R.W., Stanley, R.G., Lewis, K.A., and Haeussler, P.J., 2014, A tilted bed for the sleeping lady? Gravity and magnetic evidence for a thrust-fault interpretation of the Mt. Susitna/Beluga Mtn., in Alaska Geological Society Technical Conference, Anchorage, Alaska, May 15, 2014, Proceedings: Alaska Geological Society, accessed March 15, 2015 at http://www.alaskageology.org/documents/14/2014\%20AGS\%20Tech\%20Conf\%20Program $\%$ 20and\%20Abstracts.pdf.

Shah, A.K., Stanley, R.G., Lewis, K.A., Haeussler, P.J., Saltus, R.W., and Potter, C.J., 2014, Magnetic, seismic and well data constrain structural features of Susitna Basin, Alaska: Geological Society of America Annual Meeting 2014, Paper No. 148-4, accessed March 15, 2015 at https:/gsa.confex.com/gsa/2014AM/webprogram/Paper247645.html.

Stanley, R.G., Haeussler, P.J., Benowitz, J.A., Goodman, D.K., Ravn, R.L., Shellenbaum, D.P., Saltus, R.W., Lewis, K.A., and Potter, C.J., 2013, New stratigraphic revelations in the subsurface Susitna Basin, south-central Alaska, from geochronology and biostratigraphy: Alaska Division of Geological \& Geophysical Surveys, 1 sheet, accessed March 10, 2015 at http://www.dggs.alaska.gov/pubs/id/26887. [poster]

Stanley, R.G., Haeussler, P.J., Benowitz, J.A., Lewis, K.A., Shellenbaum, D.P., Saltus, R.W., Shah, A.K., Phillips, J.D., and Potter, C.J., 2014, Tectonic implications of new geological and geophysical results from the Susitna Basin, south-central Alaska: American Association of Petroleum Geologists Search and Discovery Article \#10608, accessed March 10, 2015 at http://www.searchanddiscovery.com/pdfz/documents/2014/10608stanley/ndx_stanley.pdf.html.

Trop, J.M., and Ridgway, K.D., 2007, Mesozoic and Cenozoic tectonic growth of southern Alaska-A sedimentary basin perspective, in Ridgway, K.D., Trop, J.M., Glen, J.M.G., and O'Neill, J.M., eds., Tectonic growth of a collisional continental margin: Crustal evolution of southern Alaska: Geological Society of America Special Paper 431, p. 55-94.

U.S. Geological Survey, 2002, Aeromagnetic Surveys in the Anchorage, Iliamna, and Tyonek Quadrangles, Alaska-A Website for the Distribution of Data: U.S. Geological Survey OpenFile Report 02-0267, http://pubs.usgs.gov/of/2002/ofr-02-0267/.

U.S. Geological Survey, 2012, Susitna 2012 magnetic survey data: U.S. Geological Survey, Mineral Resources On-Line Spatial Data, Survey ID AK_10001, accessed April 1, 2015 at http://mrdata.usgs.gov/magnetic/show-survey.php?id=10001. 
Figures

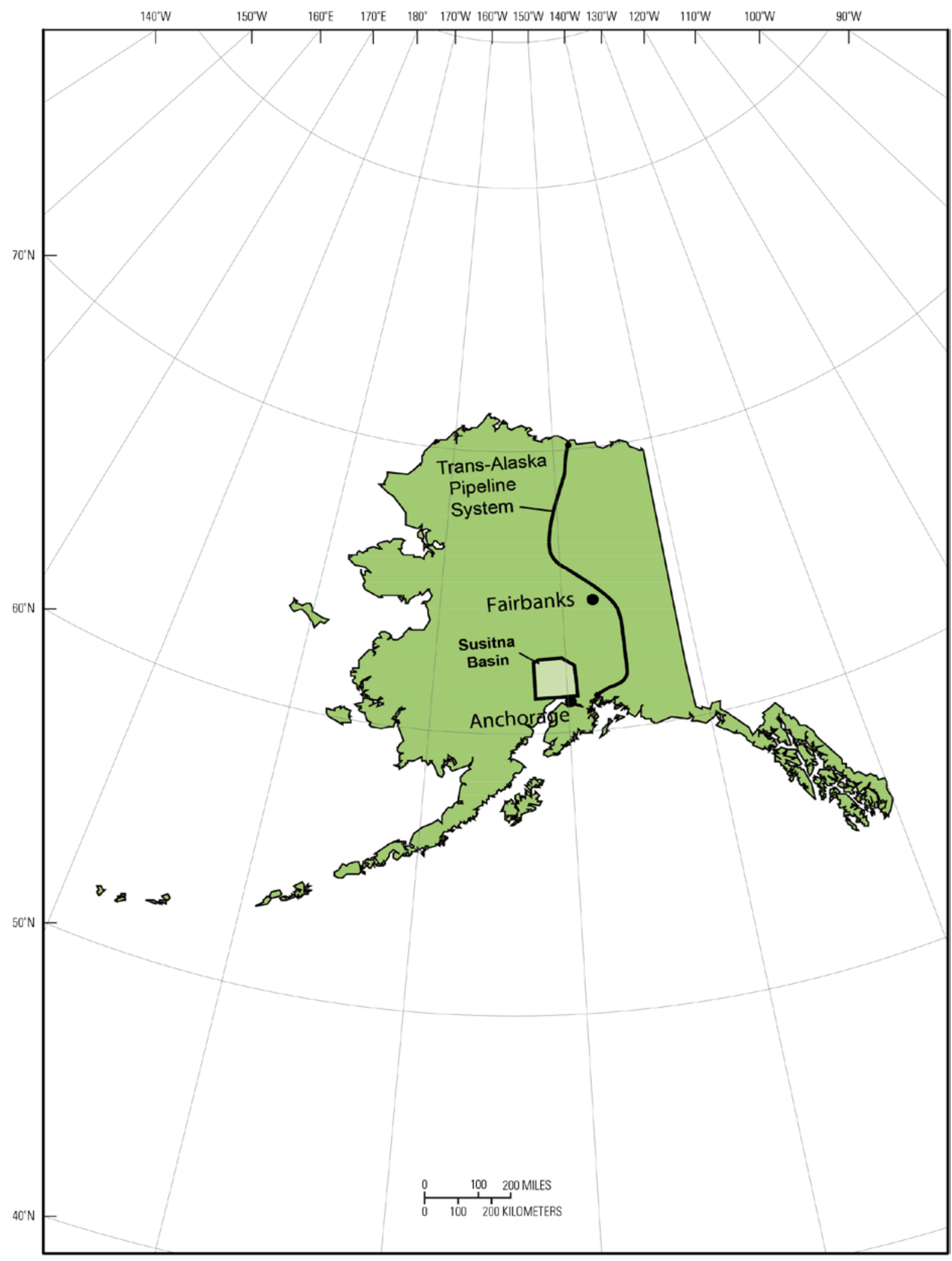

Figure 1. Map of Alaska showing the location of the study area (Susitna Basin). 


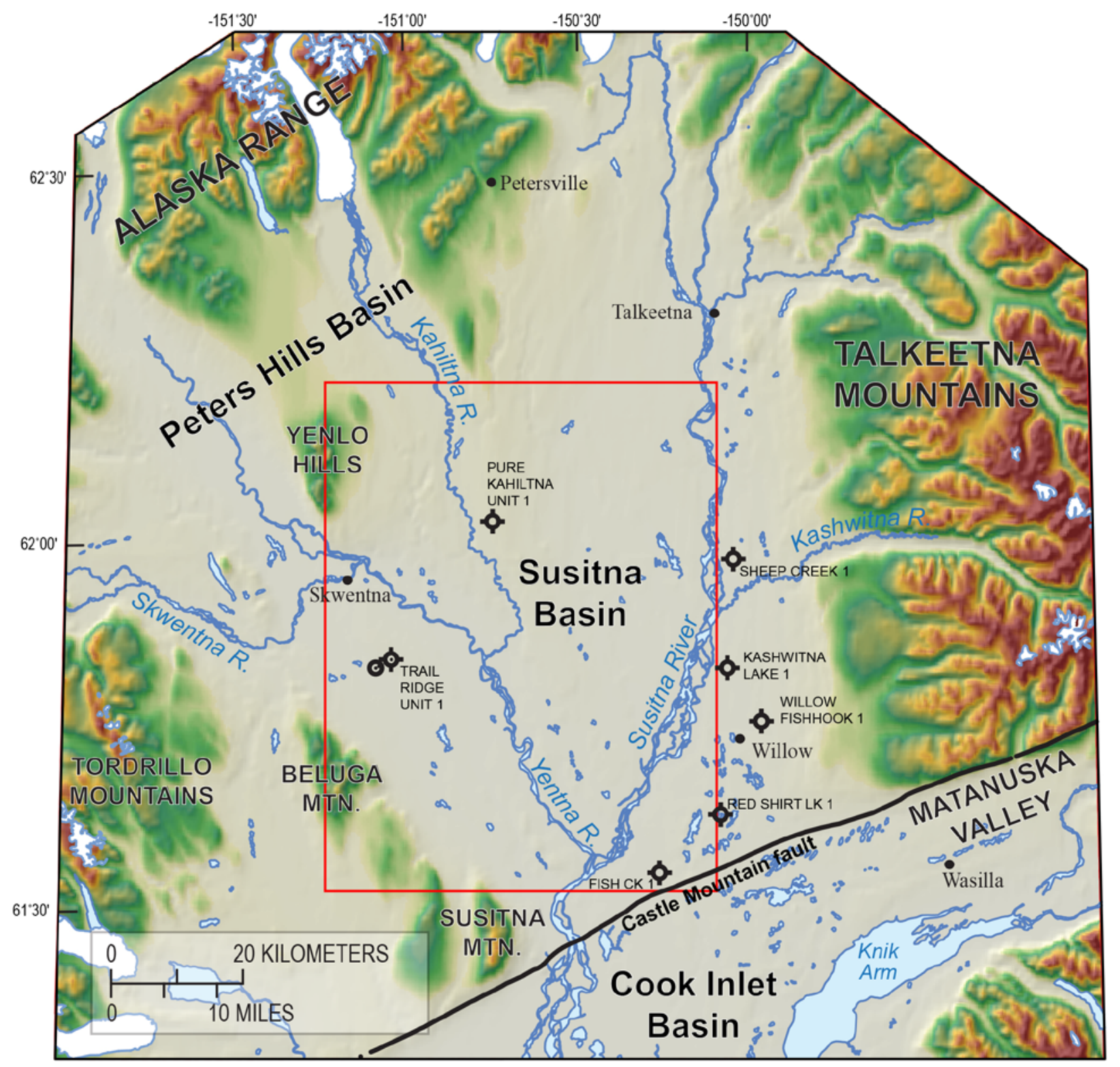

Figure 2. Map of Susitna Basin including the seven exploratory wells (Stanley and others, 2013, 2014). The red rectangle indicates the approximate area shown in figures 3 and 4 . 


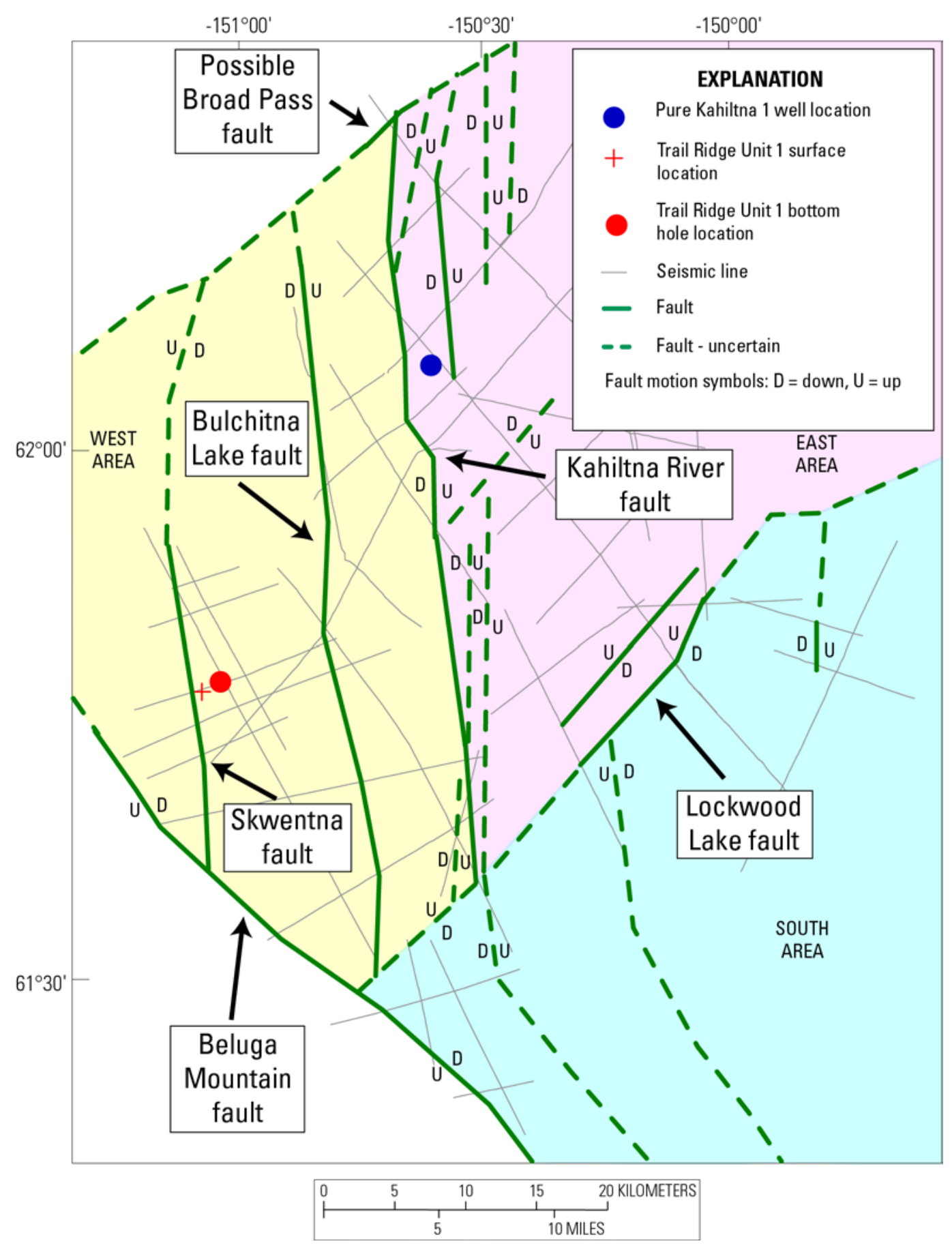

Figure 3. Fault map of the Susitna Basin seismic coverage area. Faults (all of which are interpreted to have a component of reverse slip) are indicated by green lines. Dashed fault lines identify areas of uncertainty. Relative displacement along faults is indicated by "D" and "U" symbols with D indicating down and $U$ indicating up. The industry-provided seismic lines are shown as the grey lines. The two exploratory wells that are located within the seismic coverage area, the Pure Kahiltna Unit 1 (blue circle) and Trail Ridge Unit 1 (red circle and cross), are also shown. The regional faults divide the basin into three sub-regions: east, west, and south, as indicated via the pink, yellow, and cyan shading, respectively. 


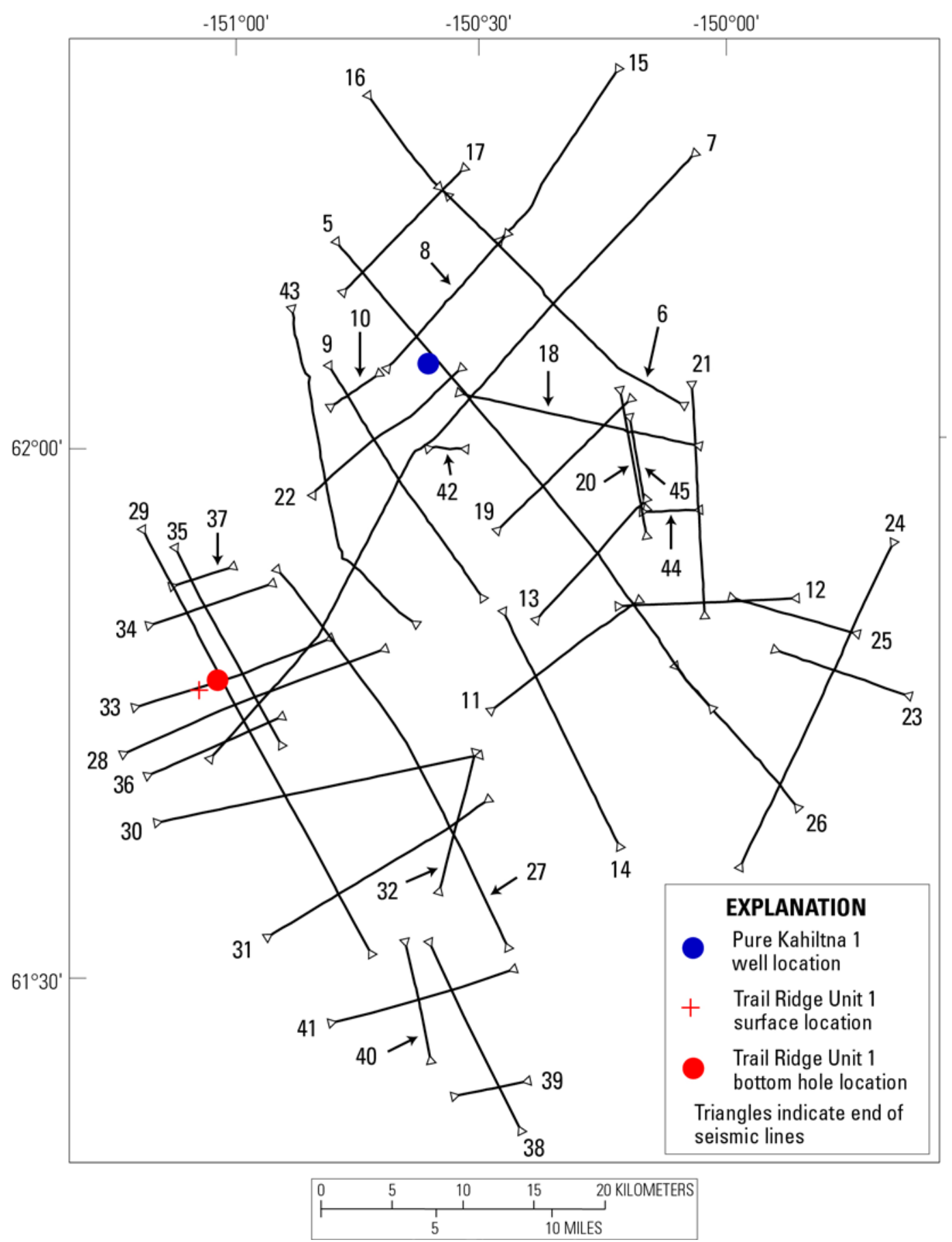

Figure 4. Seismic identification map. This map shows the 41 two-dimensional seismic lines presented in this report. Some of the seismic lines overlap, so the ends of the lines are demarcated by triangles. Line numbers labeled here correspond to the figure numbers for displays of each of the seismic lines. The exploratory wells, Pure Kahiltna Unit 1 and Trail Ridge Unit 1, are also shown. 


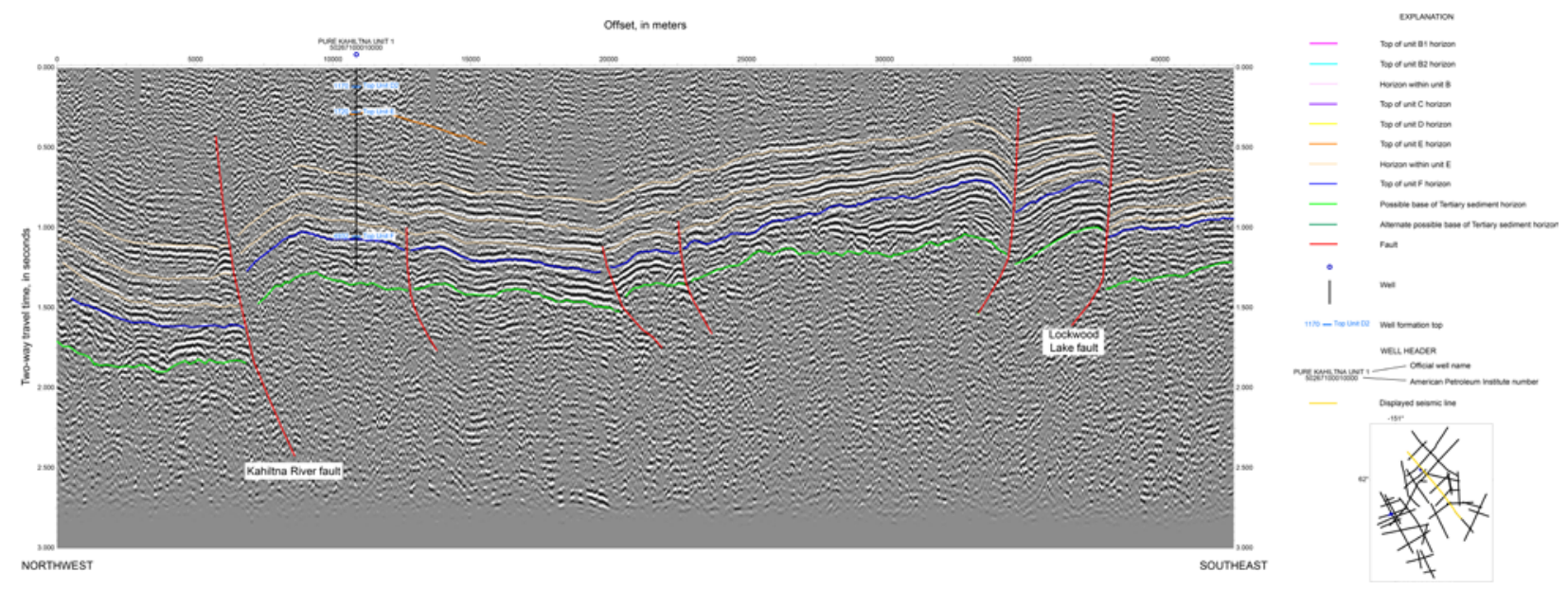

Figure 5. Seismic section 5 with interpretation. The horizontal axis is the offset along the line in meters, and the vertical axis is two-way travel time in seconds. Peaks (positive amplitudes) are black in the seismic section, while troughs (negative amplitudes) are white. The horizons shown correspond to units identified by Stanley and others $(2013,2014)$. Due to the intermittent low signal of the top unit $E$ horizon, additional horizons within unit $E$ are also shown. Faults are shown in red. The Pure Kahiltna Unit 1 exploratory well is also displayed on this line. (Click here to open full-size, high-resolution image.)
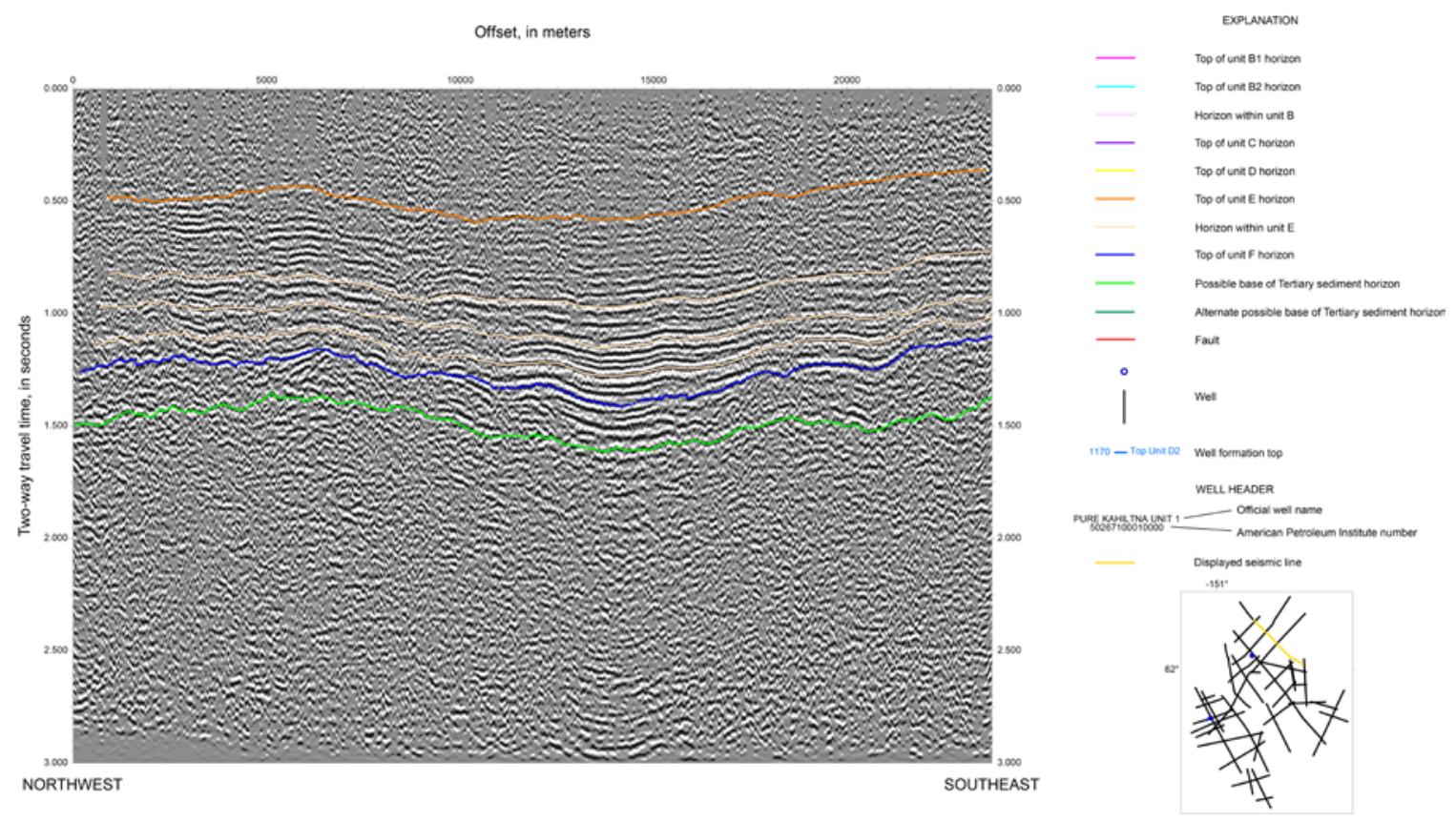

Figure 6. Seismic section 6 with interpretation. The horizontal axis is the offset along the line in meters, and the vertical axis is two-way travel time in seconds. Peaks (positive amplitudes) are black in the seismic section, while troughs (negative amplitudes) are white. The horizons shown correspond to units identified by Stanley and others $(2013,2014)$. Due to the intermittent low signal of the top unit $E$ horizon, additional horizons within unit $\mathrm{E}$ are also shown. (Click here to open full-size, high-resolution image.) 


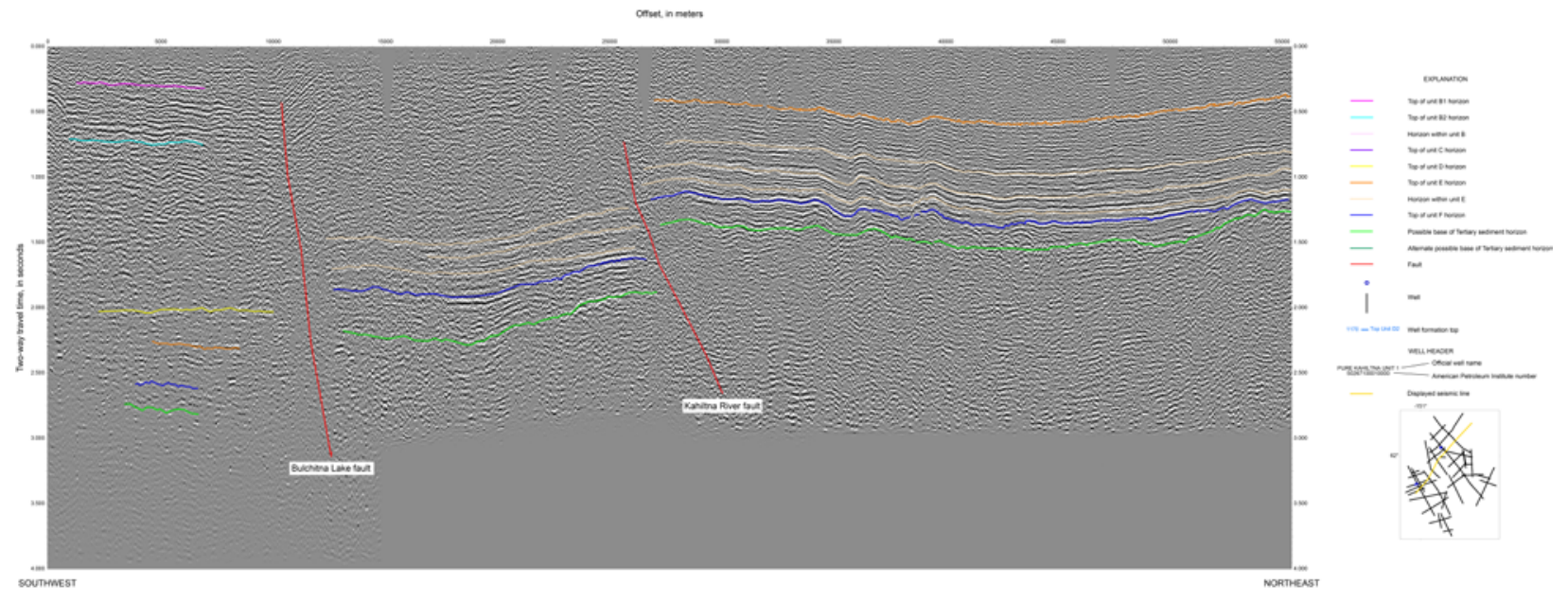

Figure 7. Seismic section 7 with interpretation. The horizontal axis is the offset along the line in meters, and the vertical axis is two-way travel time in seconds. Peaks (positive amplitudes) are black in the seismic section, while troughs (negative amplitudes) are white. The horizons shown correspond to units identified by Stanley and others $(2013,2014)$. Due to the intermittent low signal of the top unit $E$ horizon, additional horizons within unit $\mathrm{E}$ are also shown. Faults are shown in red. (Click here to open full-size, high-resolution image.) 


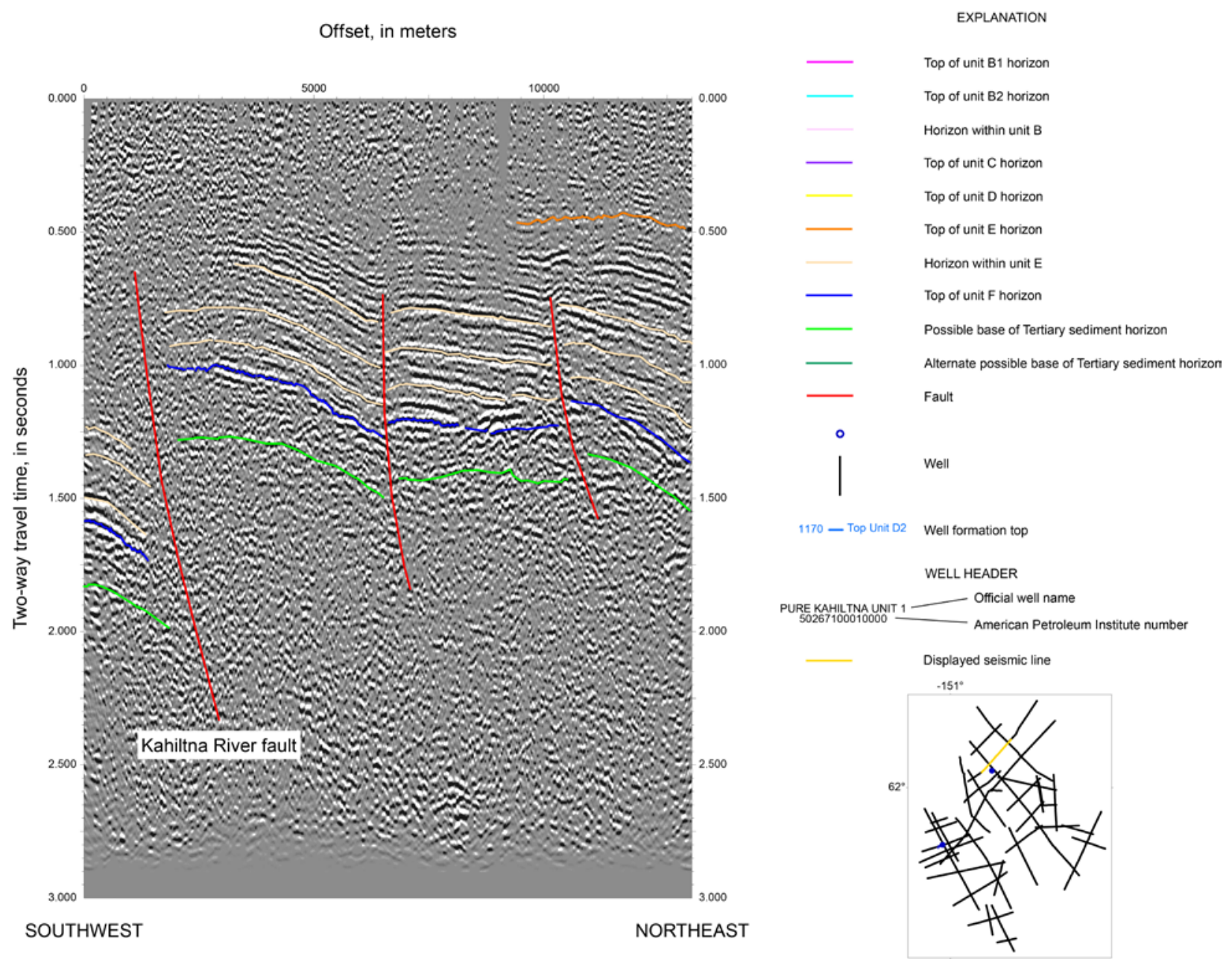

Figure 8. Seismic section 8 with interpretation. The horizontal axis is the offset along the line in meters, and the vertical axis is two-way travel time in seconds. Peaks (positive amplitudes) are black in the seismic section, while troughs (negative amplitudes) are white. The horizons shown correspond to units identified by Stanley and others $(2013,2014)$. Due to the intermittent low signal of the top unit $E$ horizon, additional horizons within unit $\mathrm{E}$ are also shown. Faults are shown in red. (Click here to open full-size, high-resolution image.) 


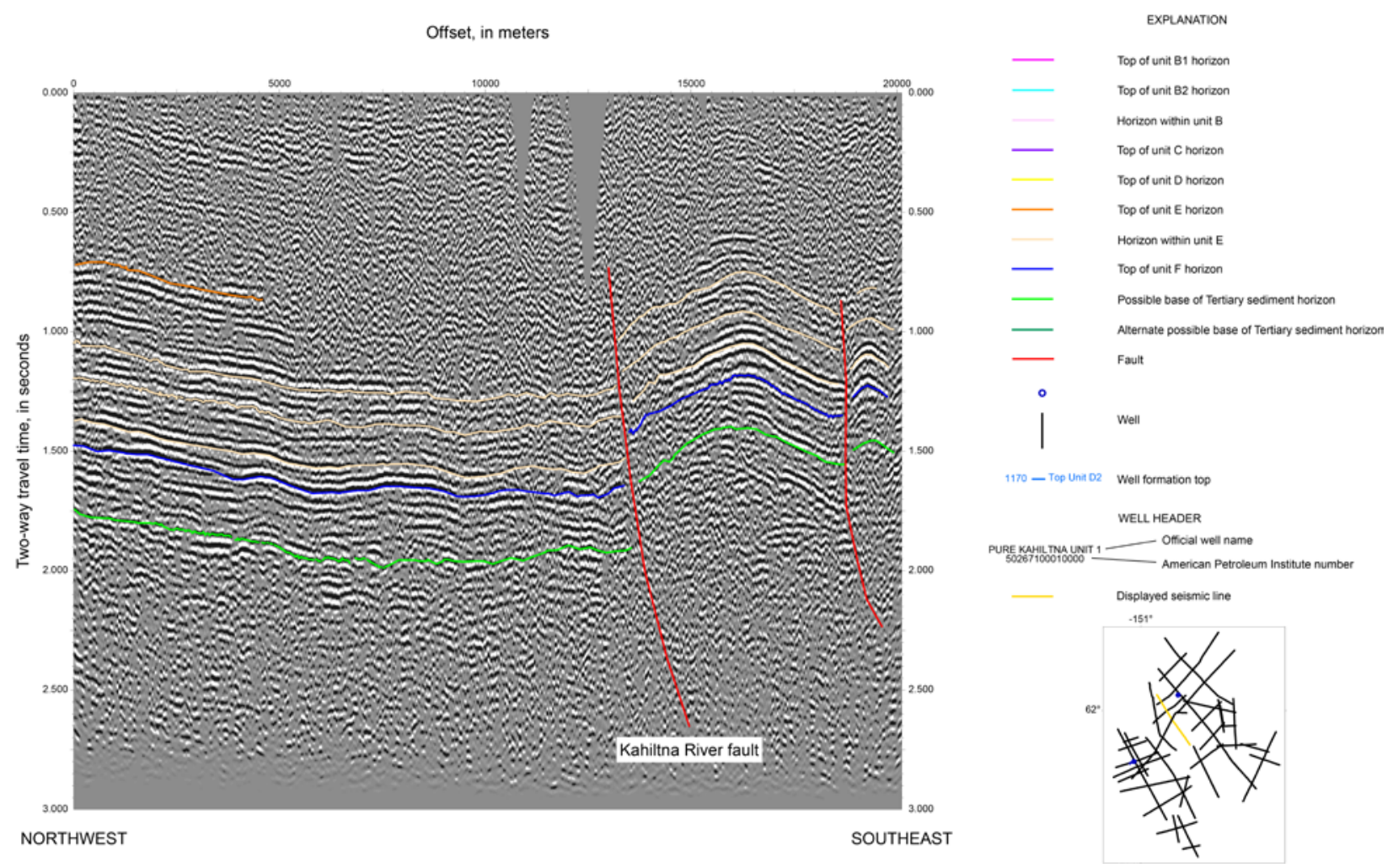

Figure 9. Seismic section 9 with interpretation. The horizontal axis is the offset along the line in meters, and the vertical axis is two-way travel time in seconds. Peaks (positive amplitudes) are black in the seismic section, while troughs (negative amplitudes) are white. The horizons shown correspond to units identified by Stanley and others $(2013,2014)$. Due to the intermittent low signal of the top unit $E$ horizon, additional horizons within unit $E$ are also shown. Faults are shown in red. (Click here to open full-size, high-resolution image.) 


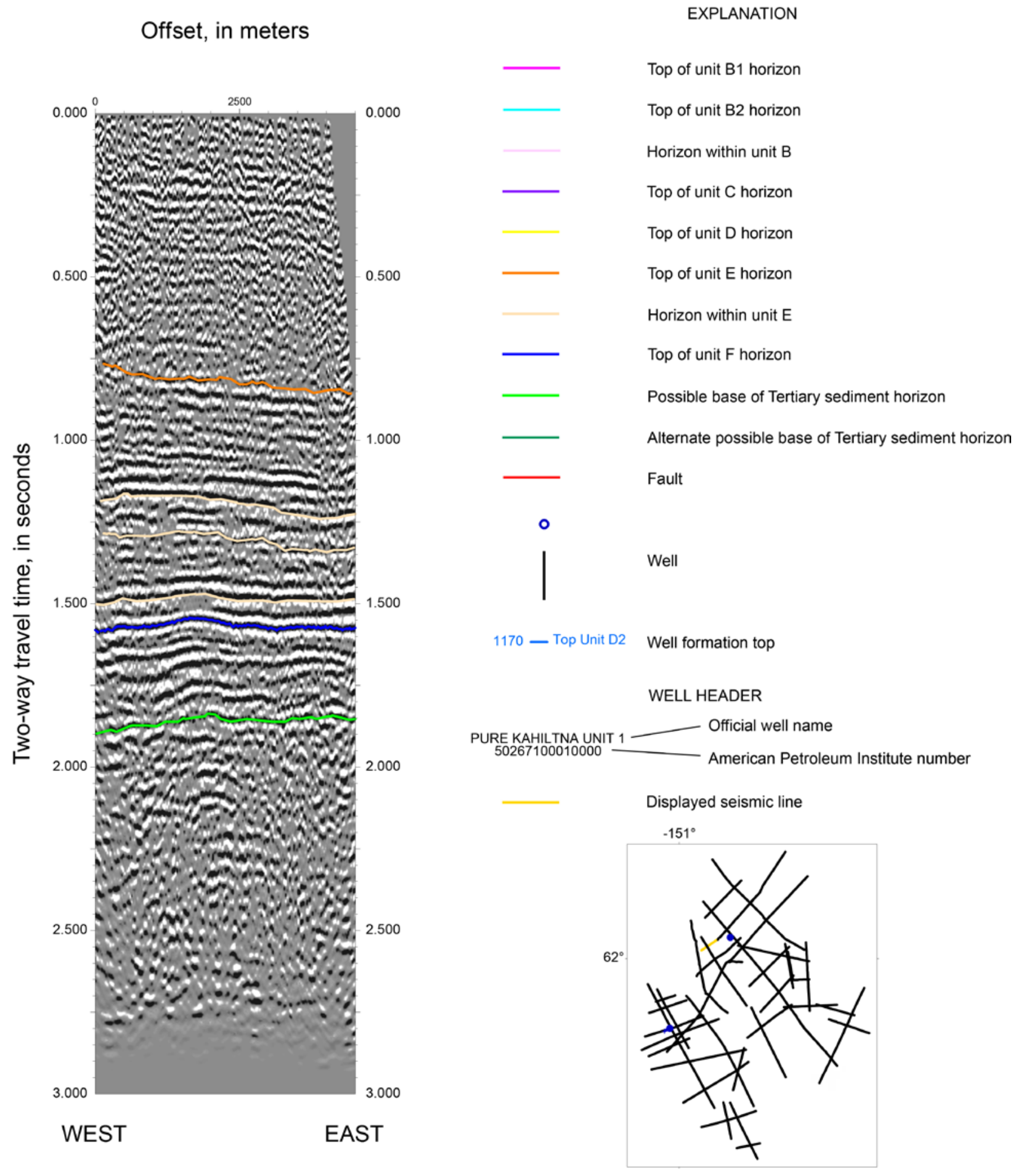

Figure 10. Seismic section 10 with interpretation. The horizontal axis is the offset along the line in meters, and the vertical axis is two-way travel time in seconds. Peaks (positive amplitudes) are black in the seismic section, while troughs (negative amplitudes) are white. The horizons shown correspond to units identified by Stanley and others $(2013,2014)$. Due to the intermittent low signal of the top unit $E$ horizon, additional horizons within unit $\mathrm{E}$ are also shown. (Click here to open full-size, high-resolution image.) 


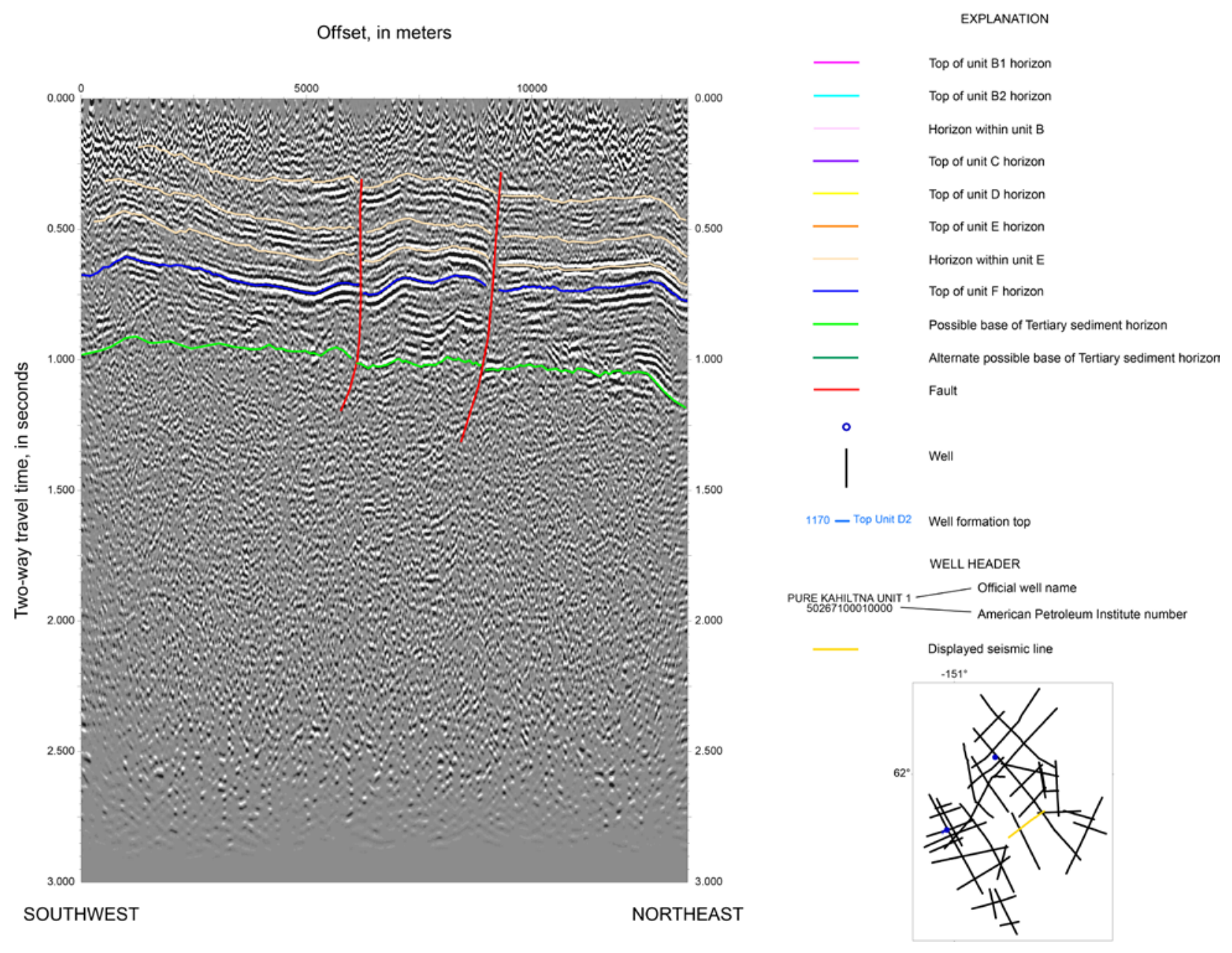

Figure 11. Seismic section 11 with interpretation. The horizontal axis is the offset along the line in meters, and the vertical axis is two-way travel time in seconds. Peaks (positive amplitudes) are black in the seismic section, while troughs (negative amplitudes) are white. The horizons shown correspond to units identified by Stanley and others $(2013,2014)$. Due to the intermittent low signal of the top unit $E$ horizon, additional horizons within unit $E$ are also shown. Faults are shown in red. (Click here to open full-size, high-resolution image.) 


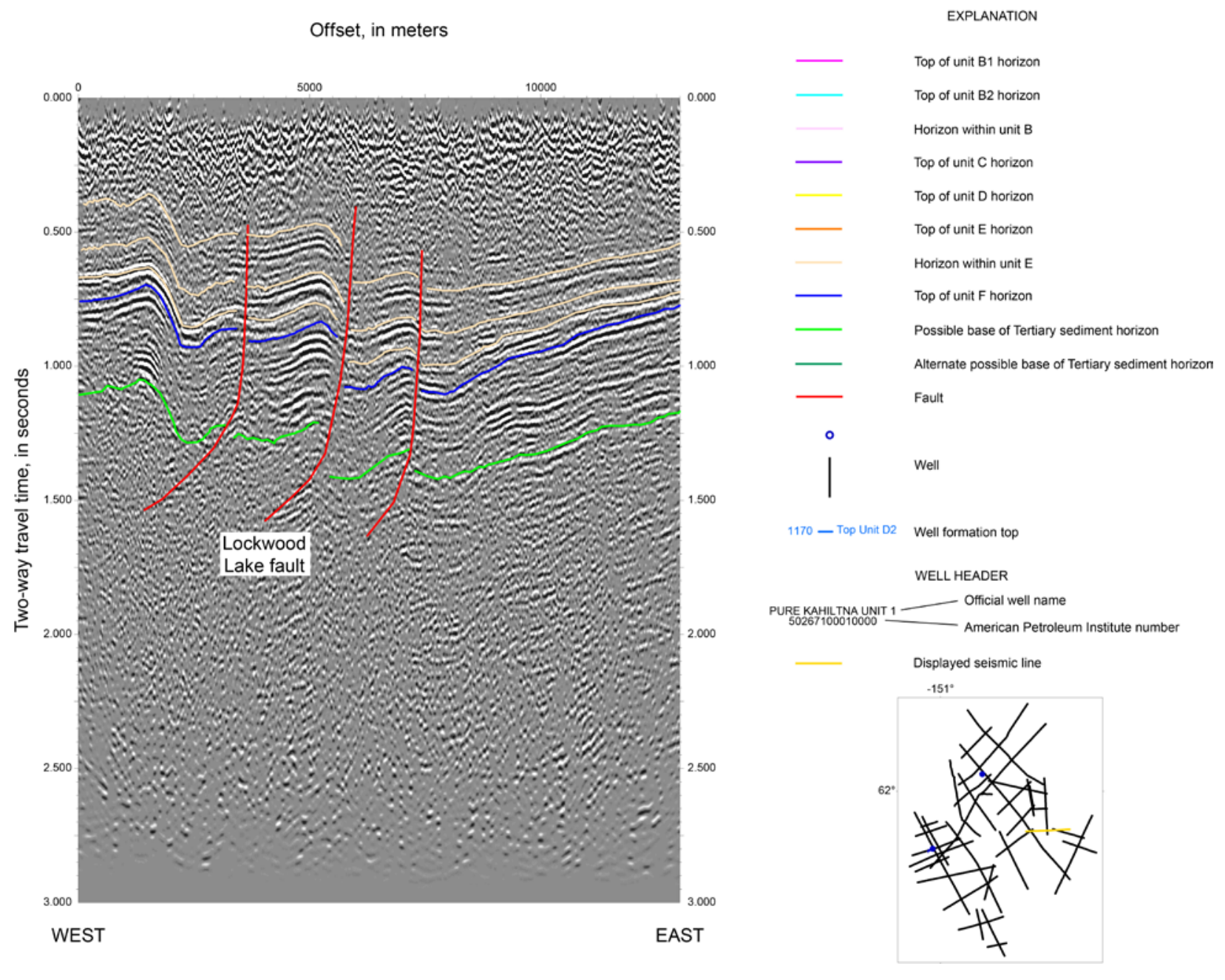

Figure 12. Seismic section 12 with interpretation. The horizontal axis is the offset along the line in meters, and the vertical axis is two-way travel time in seconds. Peaks (positive amplitudes) are black in the seismic section, while troughs (negative amplitudes) are white. The horizons shown correspond to units identified by Stanley and others $(2013,2014)$. Due to the intermittent low signal of the top unit $E$ horizon, additional horizons within unit $\mathrm{E}$ are also shown. Faults are shown in red. (Click here to open full-size, high-resolution image.) 


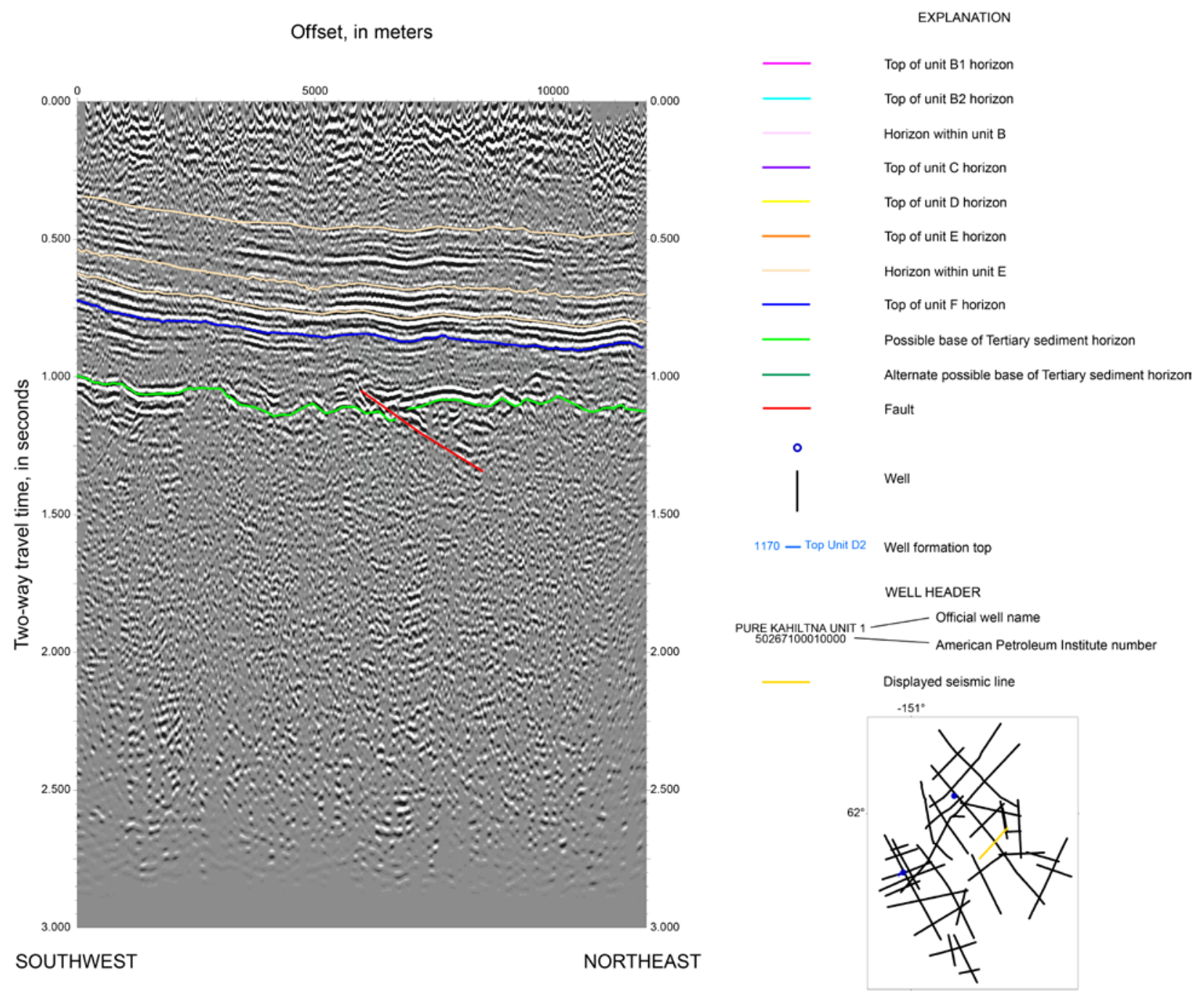

Figure 13. Seismic section 13 with interpretation. The horizontal axis is the offset along the line in meters, and the vertical axis is two-way travel time in seconds. Peaks (positive amplitudes) are black in the seismic section, while troughs (negative amplitudes) are white. The horizons shown correspond to units identified by Stanley and others $(2013,2014)$. Due to the intermittent low signal of the top unit $E$ horizon, additional horizons within unit $E$ are also shown. Faults are shown in red. (Click here to open full-size, high-resolution image.) 


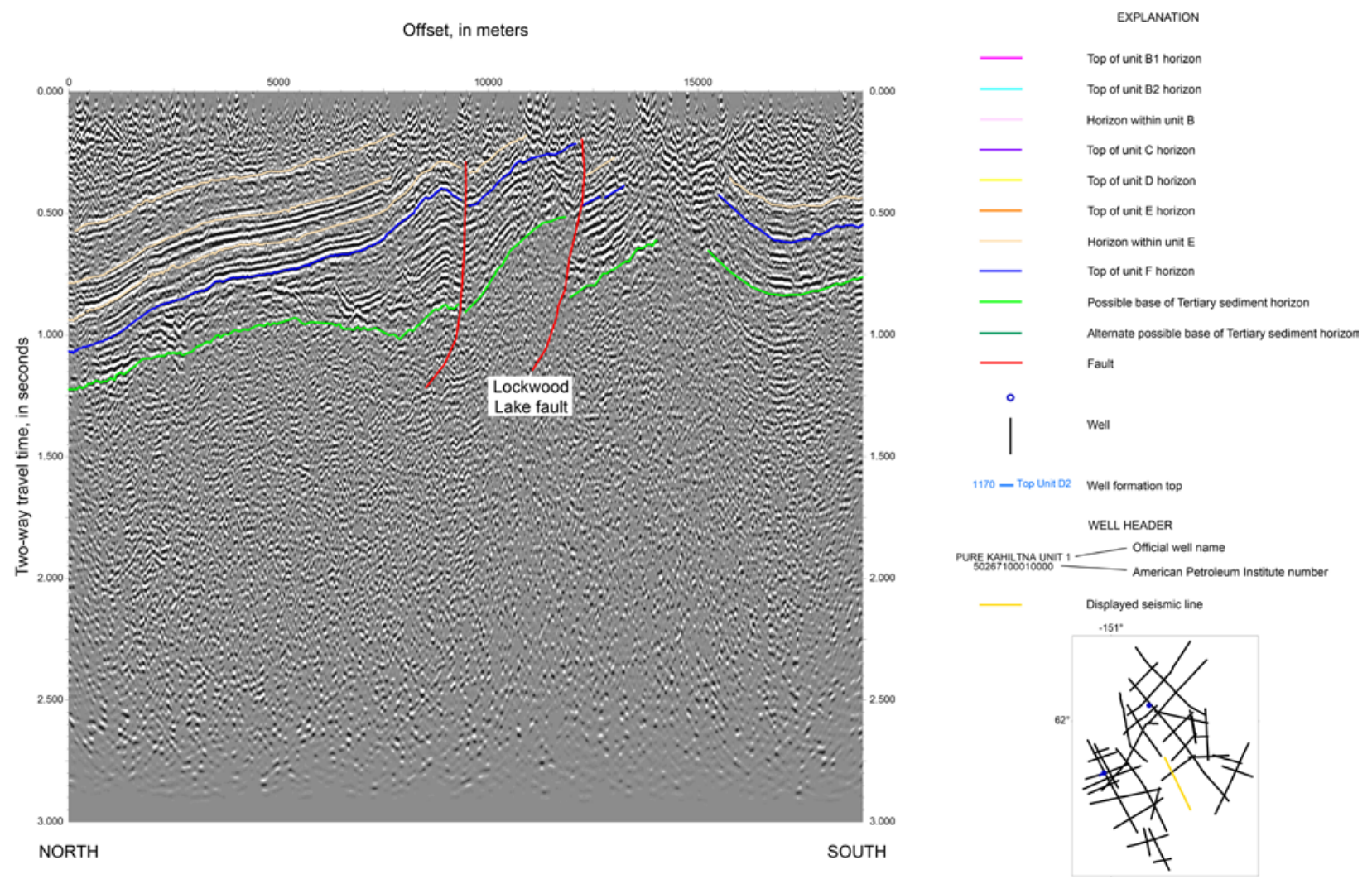

Figure 14. Seismic section 14 with interpretation. The horizontal axis is the offset along the line in meters, and the vertical axis is two-way travel time in seconds. Peaks (positive amplitudes) are black in the seismic section, while troughs (negative amplitudes) are white. The horizons shown correspond to units identified by Stanley and others $(2013,2014)$. Due to the intermittent low signal of the top unit $E$ horizon, additional horizons within unit $\mathrm{E}$ are also shown. Faults are shown in red. (Click here to open full-size, high-resolution image.) 


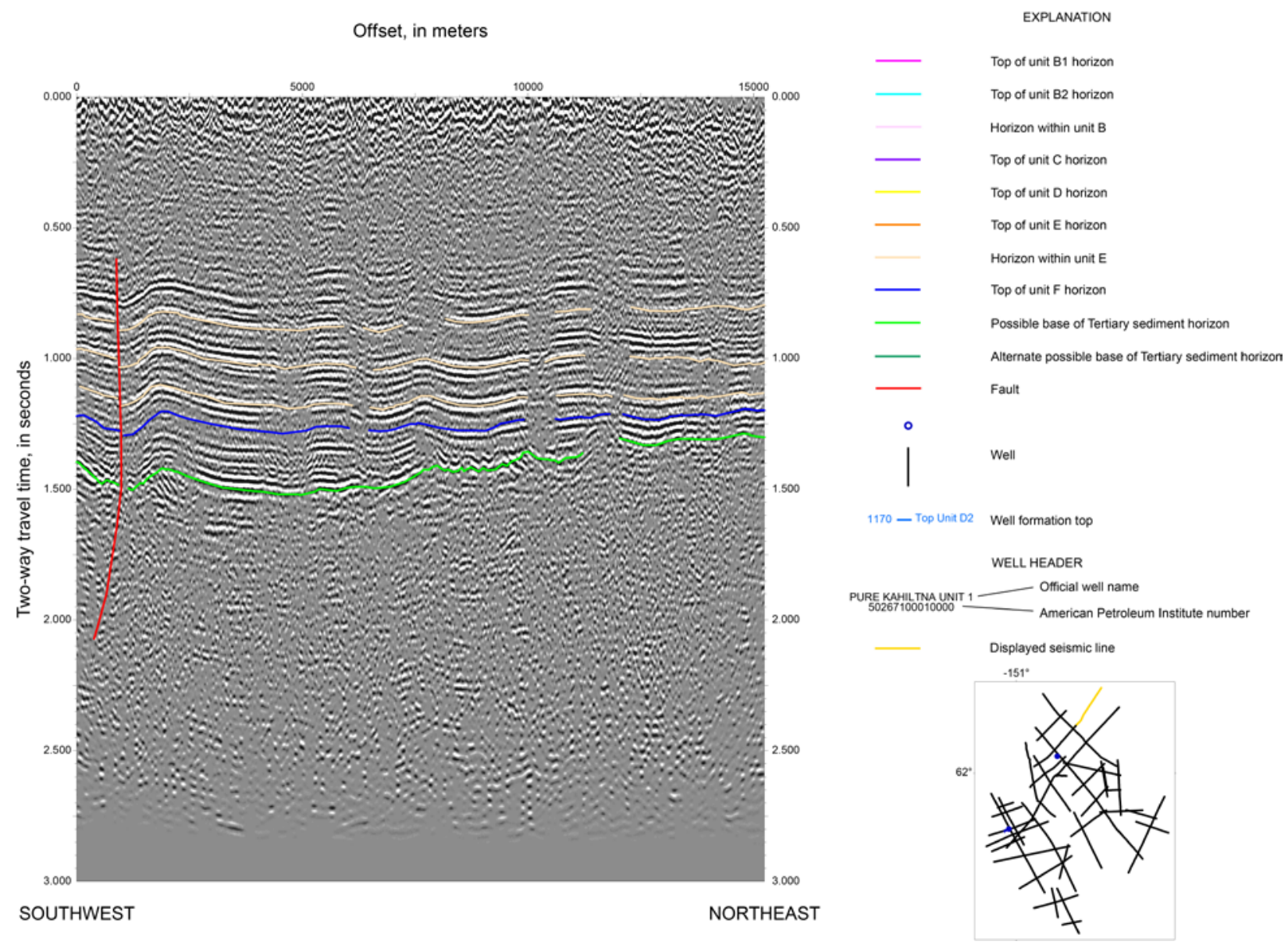

Figure 15. Seismic section 15 with interpretation. The horizontal axis is the offset along the line in meters, and the vertical axis is two-way travel time in seconds. Peaks (positive amplitudes) are black in the seismic section, while troughs (negative amplitudes) are white. The horizons shown correspond to units identified by Stanley and others $(2013,2014)$. Due to the intermittent low signal of the top unit $E$ horizon, additional horizons within unit $\mathrm{E}$ are also shown. Faults are shown in red. (Click here to open full-size, high-resolution image.) 


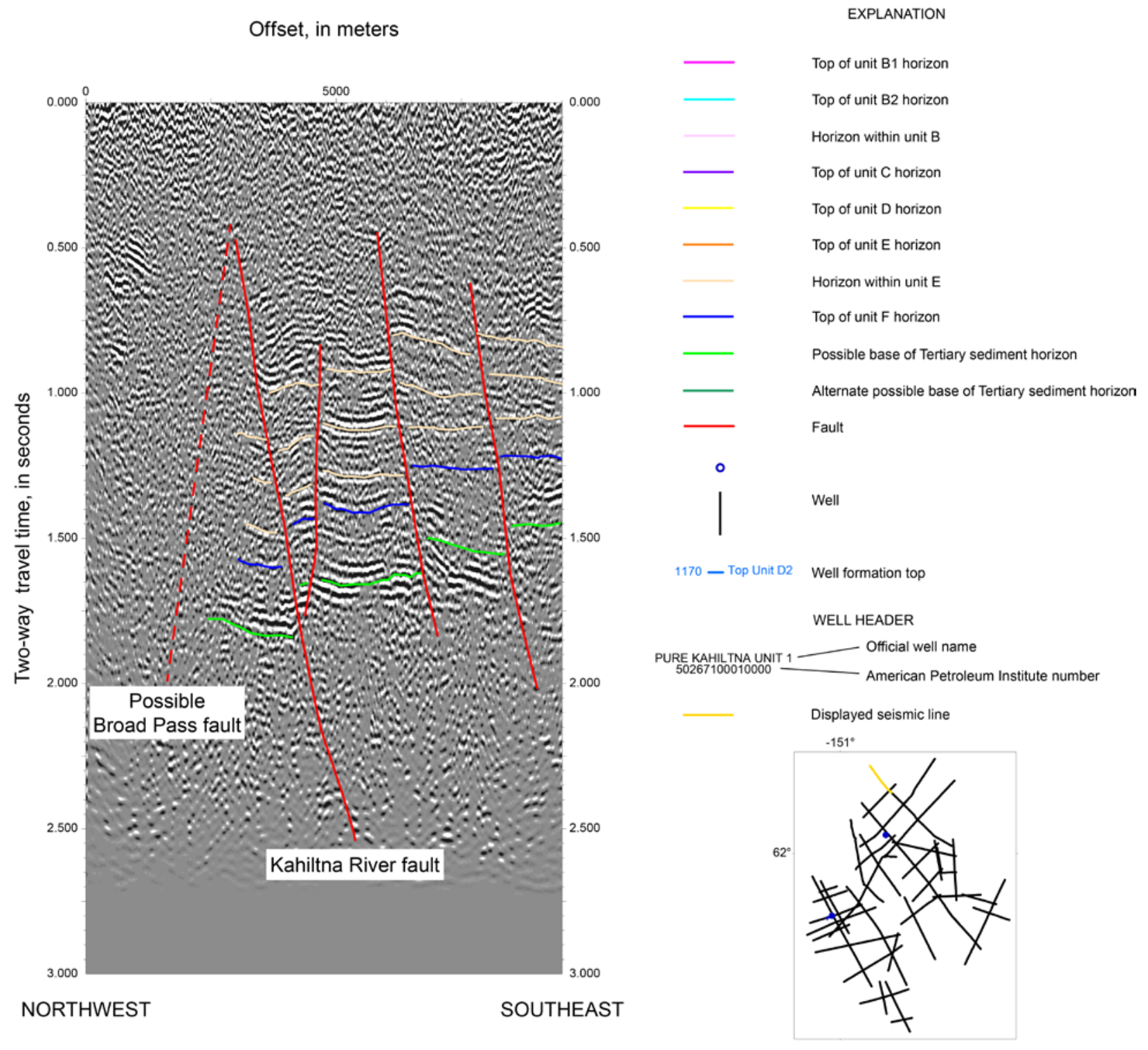

Figure 16. Seismic section 16 with interpretation. The horizontal axis is the offset along the line in meters, and the vertical axis is two-way travel time in seconds. Peaks (positive amplitudes) are black in the seismic section, while troughs (negative amplitudes) are white. The horizons shown correspond to units identified by Stanley and others $(2013,2014)$. Due to the intermittent low signal of the top unit $E$ horizon, additional horizons within unit $\mathrm{E}$ are also shown. Faults are shown in red. (Click here to open full-size, high-resolution image.) 


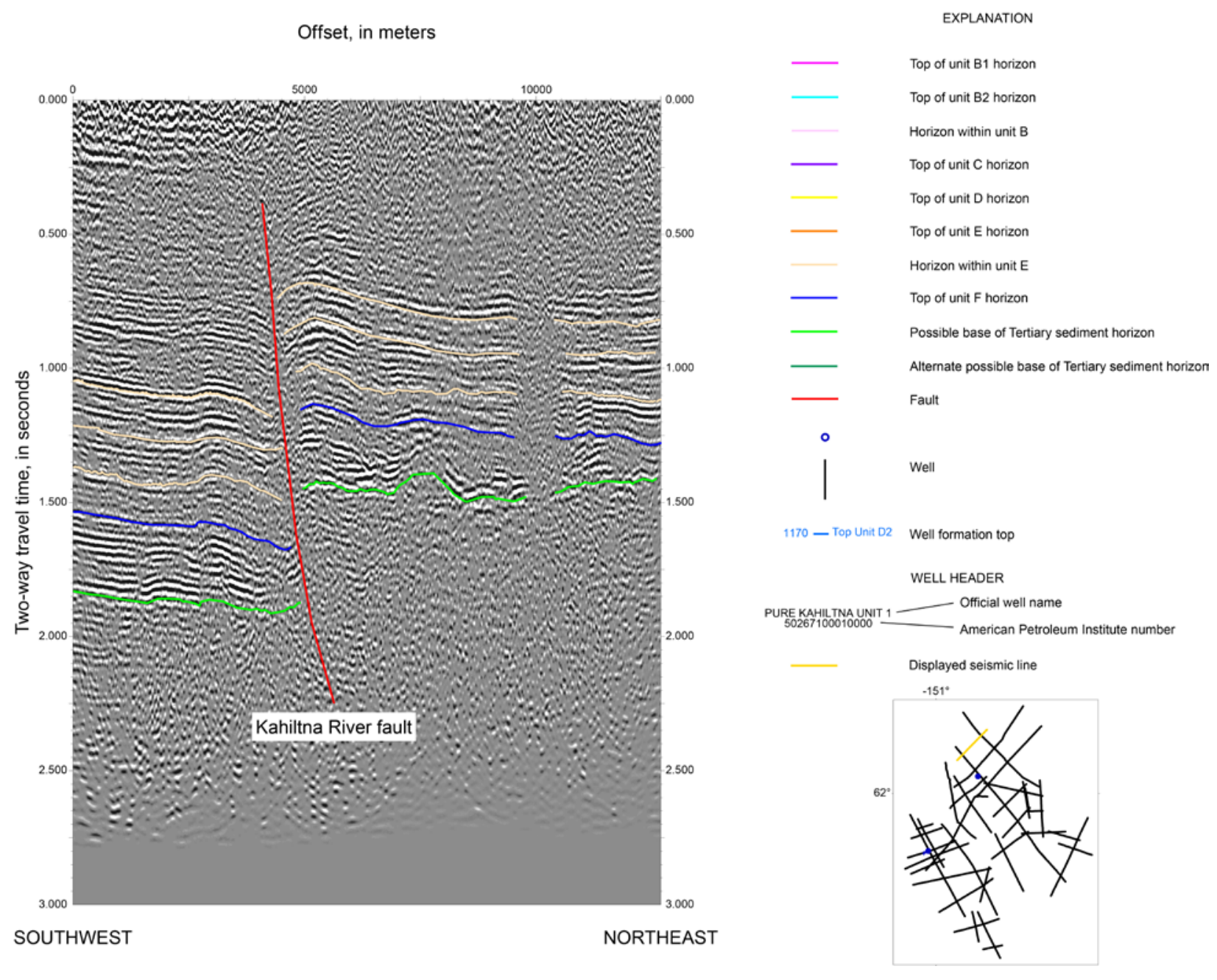

Figure 17. Seismic section 17 with interpretation. The horizontal axis is the offset along the line in meters, and the vertical axis is two-way travel time in seconds. Peaks (positive amplitudes) are black in the seismic section, while troughs (negative amplitudes) are white. The horizons shown correspond to units identified by Stanley and others $(2013,2014)$. Due to the intermittent low signal of the top unit $E$ horizon, additional horizons within unit $\mathrm{E}$ are also shown. Faults are shown in red. (Click here to open full-size, high-resolution image.) 


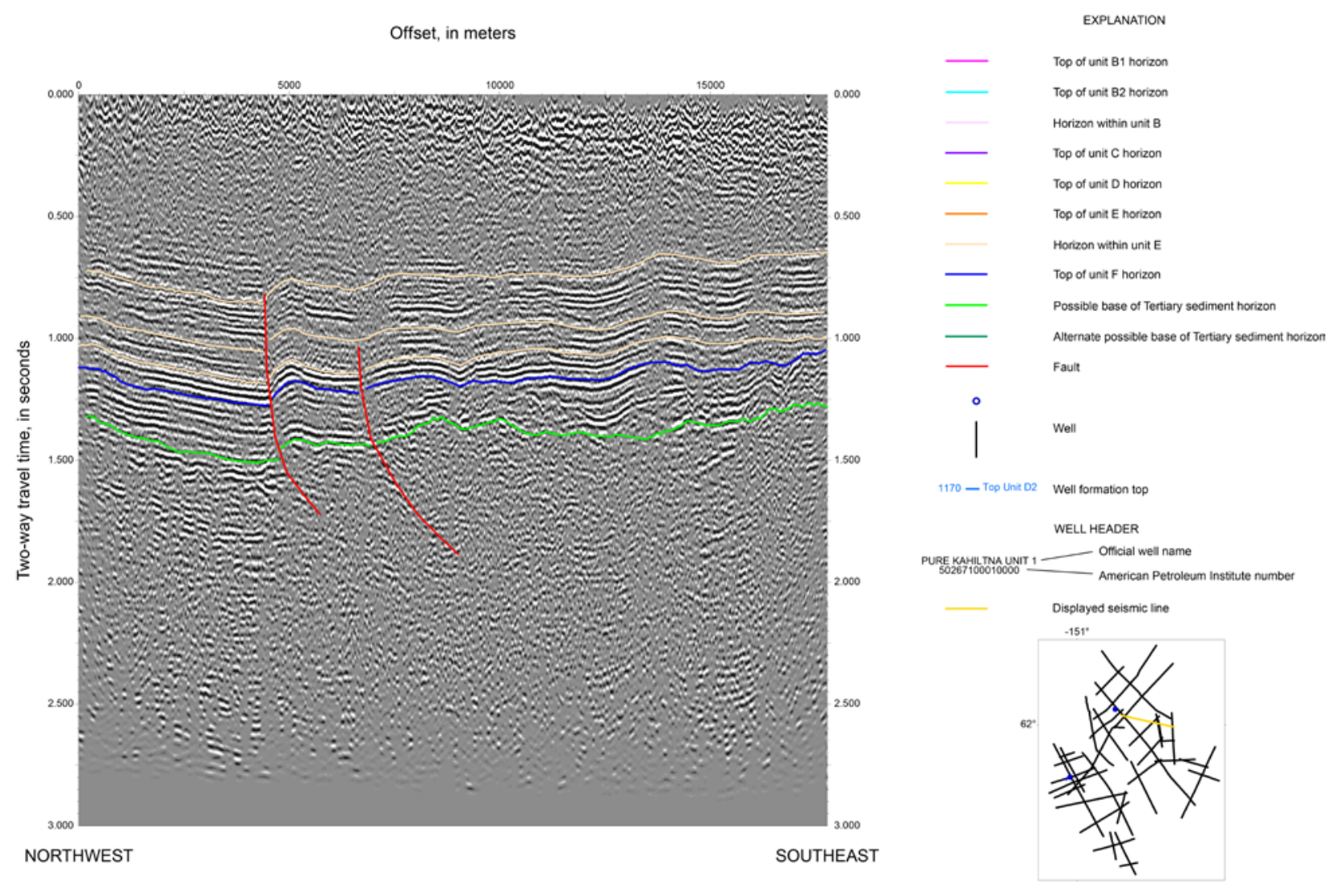

Figure 18. Seismic section 18 with interpretation. The horizontal axis is the offset along the line in meters, and the vertical axis is two-way travel time in seconds. Peaks (positive amplitudes) are black in the seismic section, while troughs (negative amplitudes) are white. The horizons shown correspond to units identified by Stanley and others $(2013,2014)$. Due to the intermittent low signal of the top unit $E$ horizon, additional horizons within unit $\mathrm{E}$ are also shown. Faults are shown in red. (Click here to open full-size, high-resolution image.) 


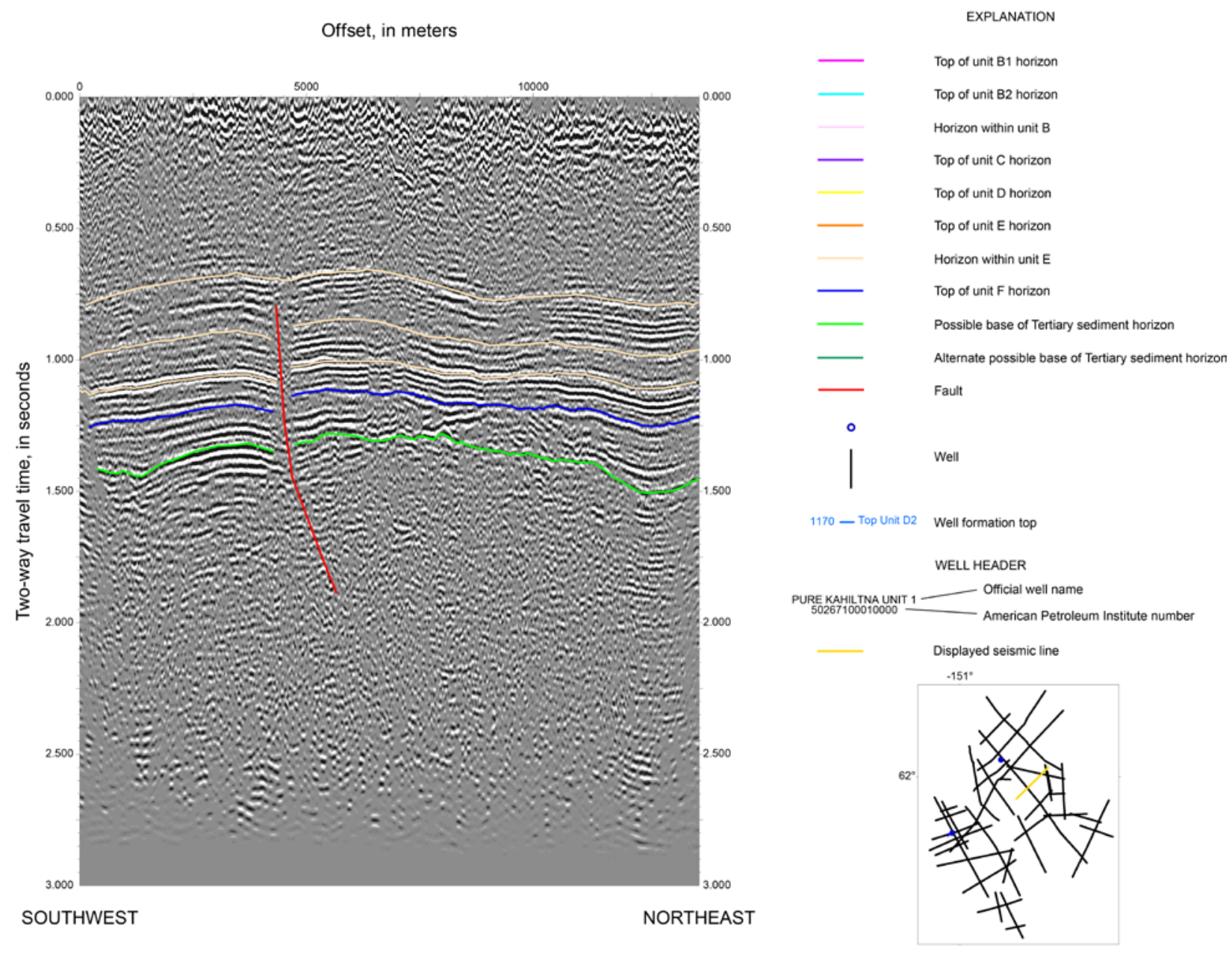

Figure 19. Seismic section 19 with interpretation. The horizontal axis is the offset along the line in meters, and the vertical axis is two-way travel time in seconds. Peaks (positive amplitudes) are black in the seismic section, while troughs (negative amplitudes) are white. The horizons shown correspond to units identified by Stanley and others $(2013,2014)$. Due to the intermittent low signal of the top unit $E$ horizon, additional horizons within unit $E$ are also shown. Faults are shown in red. (Click here to open full-size, high-resolution image.) 

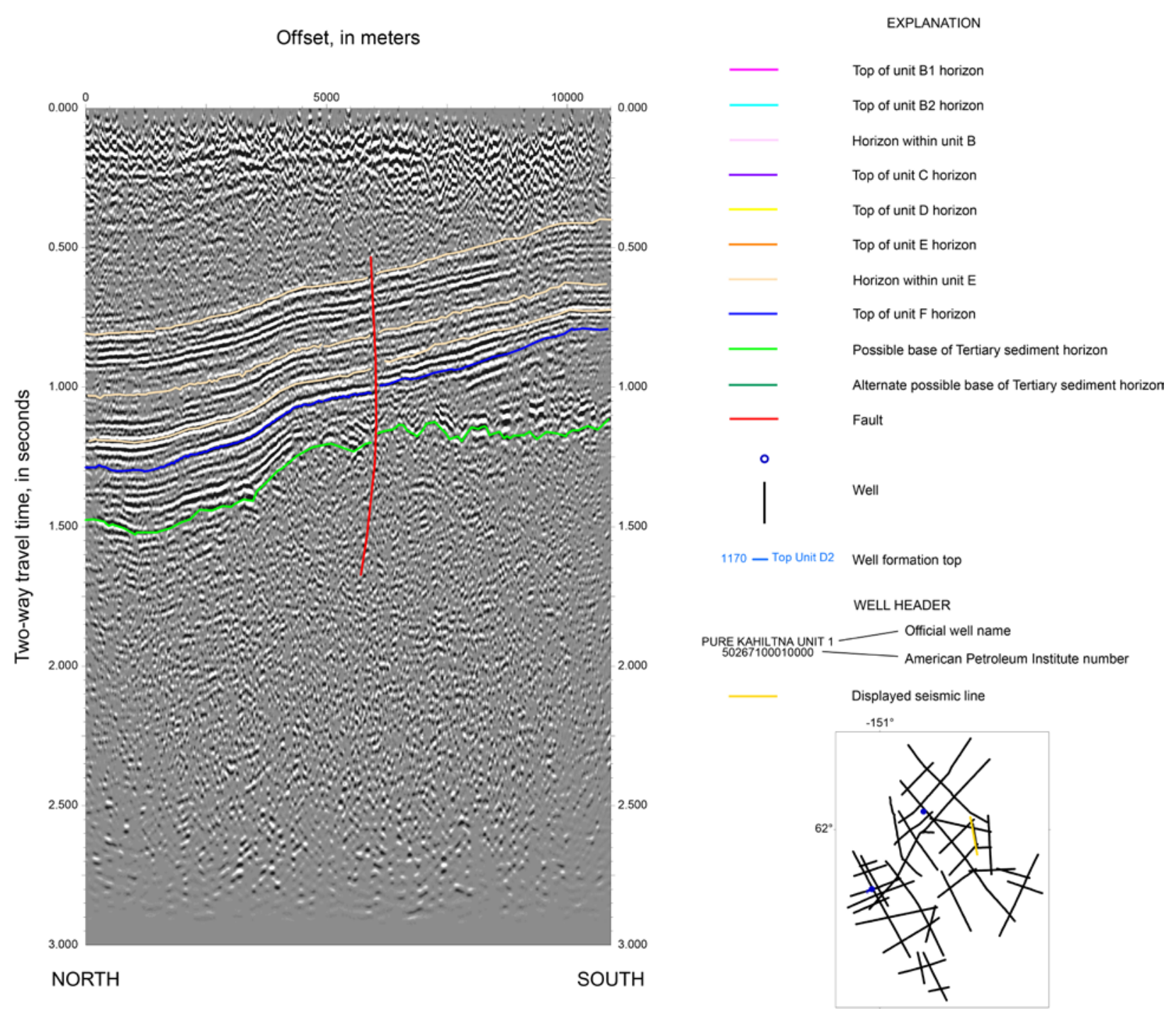

Figure 20. Seismic section 20 with interpretation. The horizontal axis is the offset along the line in meters, and the vertical axis is two-way travel time in seconds. Peaks (positive amplitudes) are black in the seismic section, while troughs (negative amplitudes) are white. The horizons shown correspond to units identified by Stanley and others $(2013,2014)$. Due to the intermittent low signal of the top unit $E$ horizon, additional horizons within unit $\mathrm{E}$ are also shown. Faults are shown in red. (Click here to open full-size, high-resolution image.) 


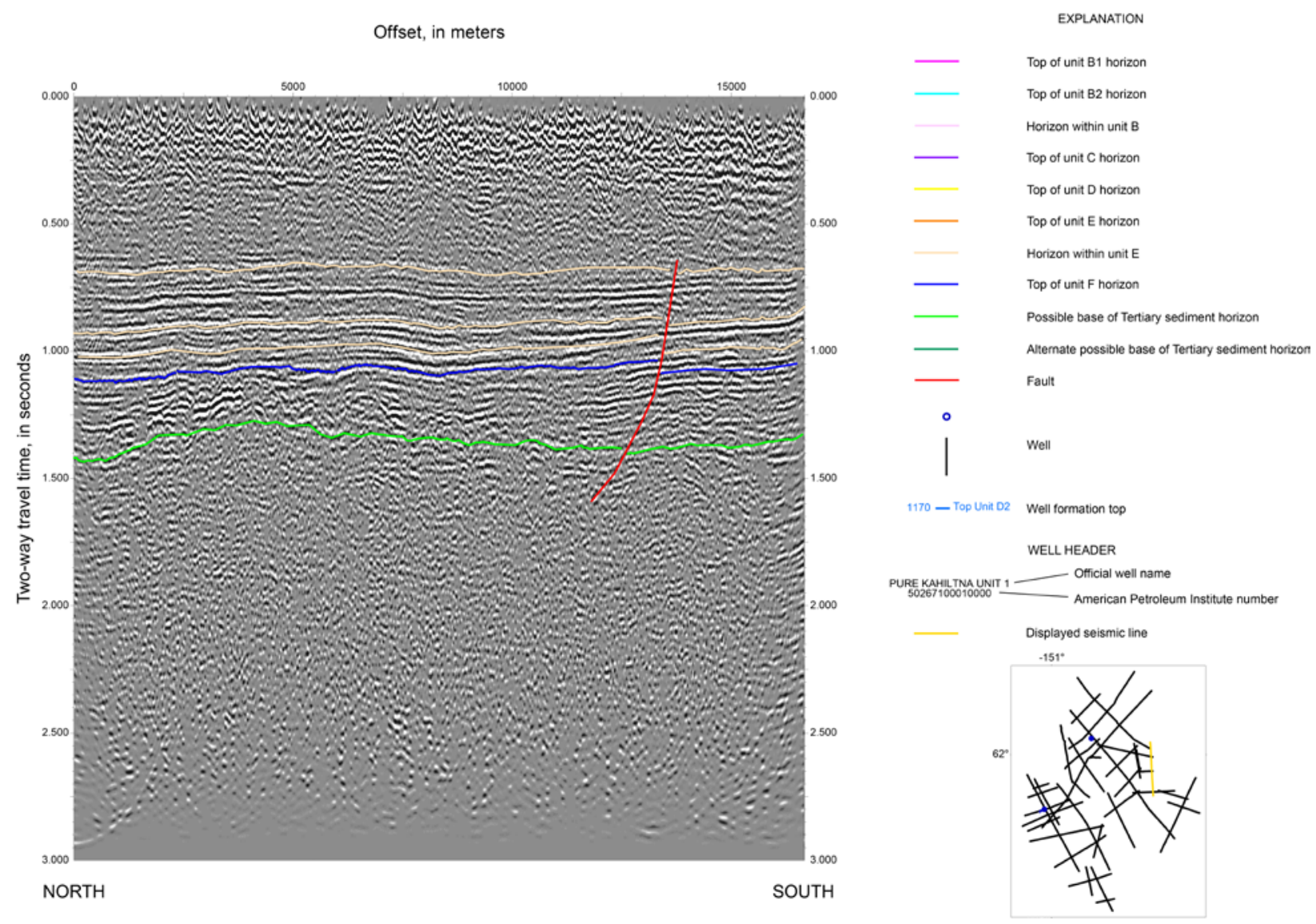

Figure 21. Seismic section 21 with interpretation. The horizontal axis is the offset along the line in meters, and the vertical axis is two-way travel time in seconds. Peaks (positive amplitudes) are black in the seismic section, while troughs (negative amplitudes) are white. The horizons shown correspond to units identified by Stanley and others $(2013,2014)$. Due to the intermittent low signal of the top unit $E$ horizon, additional horizons within unit $E$ are also shown. Faults are shown in red. (Click here to open full-size, high-resolution image.) 


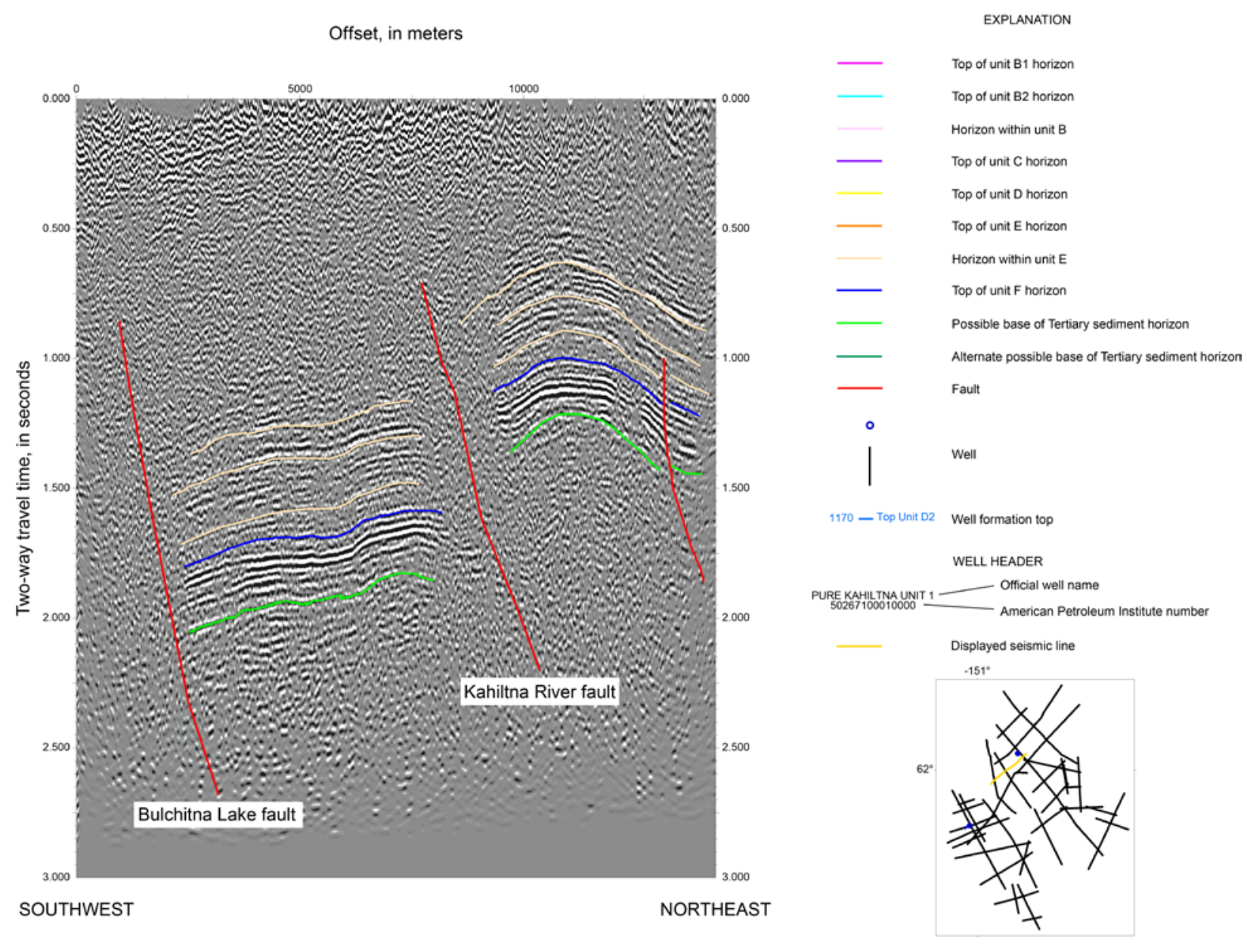

Figure 22. Seismic section 22 with interpretation. The horizontal axis is the offset along the line in meters, and the vertical axis is two-way travel time in seconds. Peaks (positive amplitudes) are black in the seismic section, while troughs (negative amplitudes) are white. The horizons shown correspond to units identified by Stanley and others $(2013,2014)$. Due to the intermittent low signal of the top unit $E$ horizon, additional horizons within unit $\mathrm{E}$ are also shown. Faults are shown in red. (Click here to open full-size, high-resolution image.) 


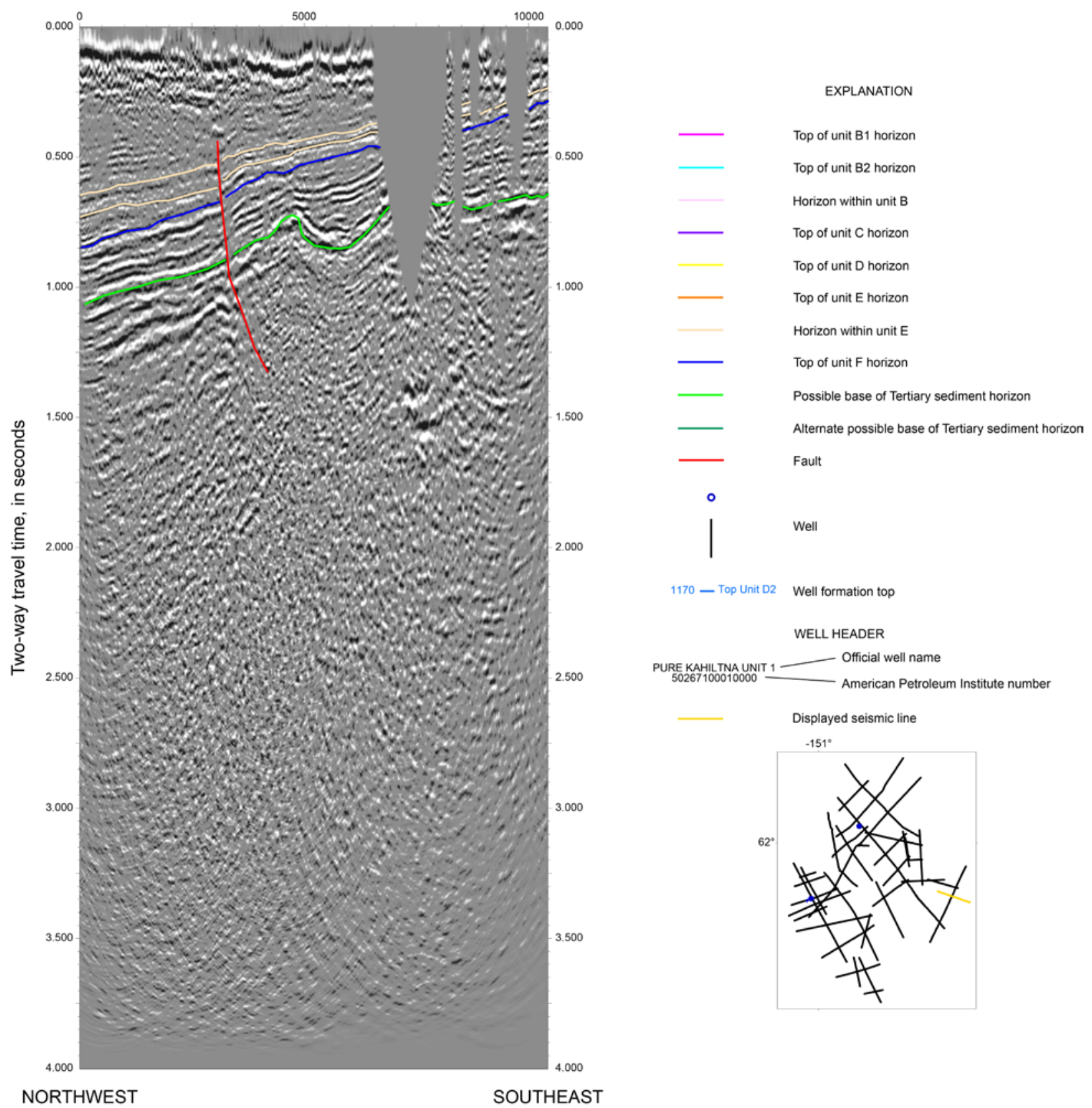

Figure 23. Seismic section 23 with interpretation. The horizontal axis is the offset along the line in meters, and the vertical axis is two-way travel time in seconds. Peaks (positive amplitudes) are black in the seismic section, while troughs (negative amplitudes) are white. The horizons shown correspond to units identified by Stanley and others $(2013,2014)$. Due to the intermittent low signal of the top unit $E$ horizon, additional horizons within unit $\mathrm{E}$ are also shown. Faults are shown in red. (Click here to open full-size, high-resolution image.) 


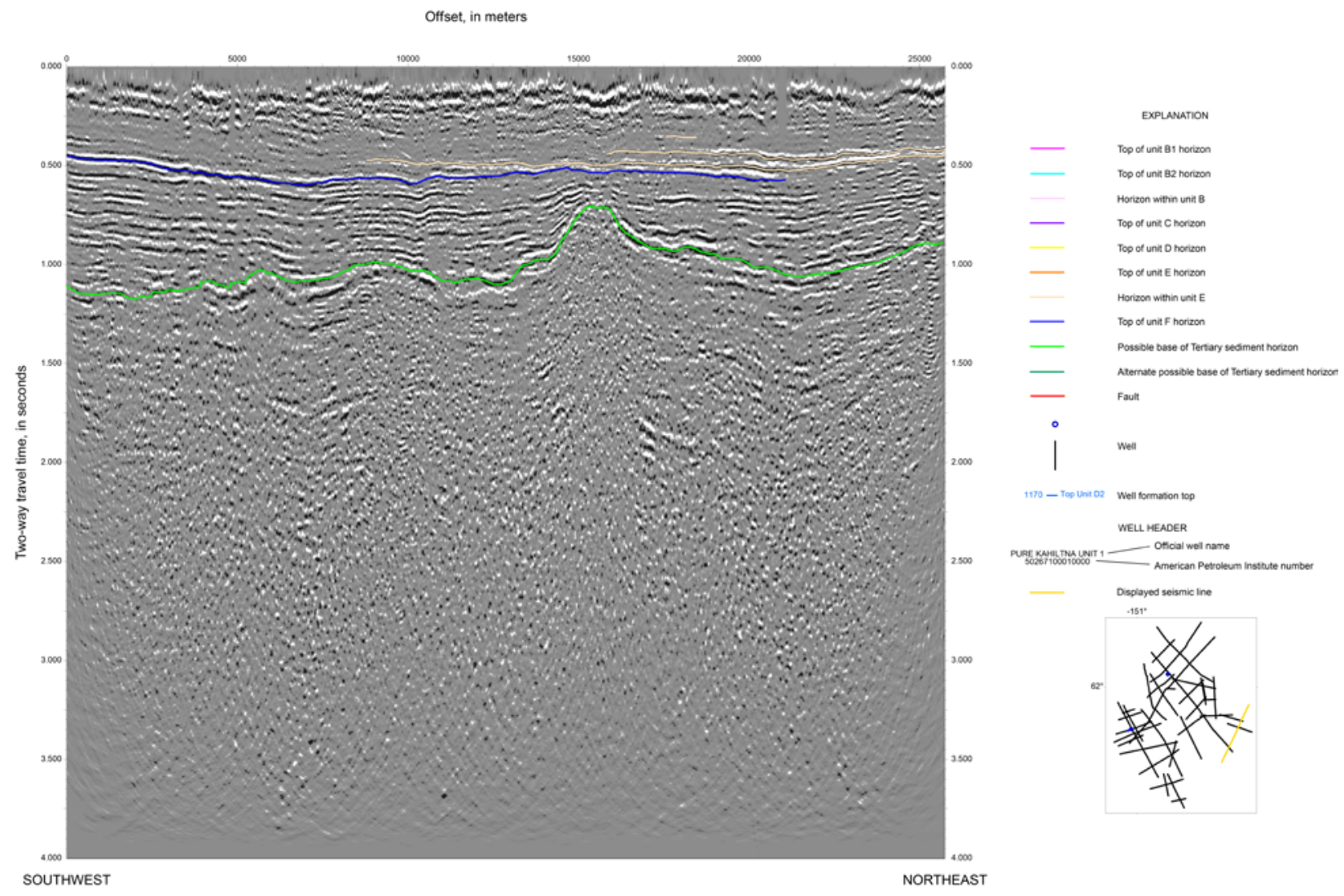

Figure 24. Seismic section 24 with interpretation. The horizontal axis is the offset along the line in meters, and the vertical axis is two-way travel time in seconds. Peaks (positive amplitudes) are black in the seismic section, while troughs (negative amplitudes) are white. The horizons shown correspond to units identified by Stanley and others $(2013,2014)$. Due to the intermittent low signal of the top unit $E$ horizon, additional horizons within unit $E$ are also shown. There appears to be evidence of onlap onto the base Tertiary horizon near the domal feature (offset roughly 15,000 meters) on this line. At this time, the origin of this domal feature is unknown. (Click here to open full-size, high-resolution image.) 


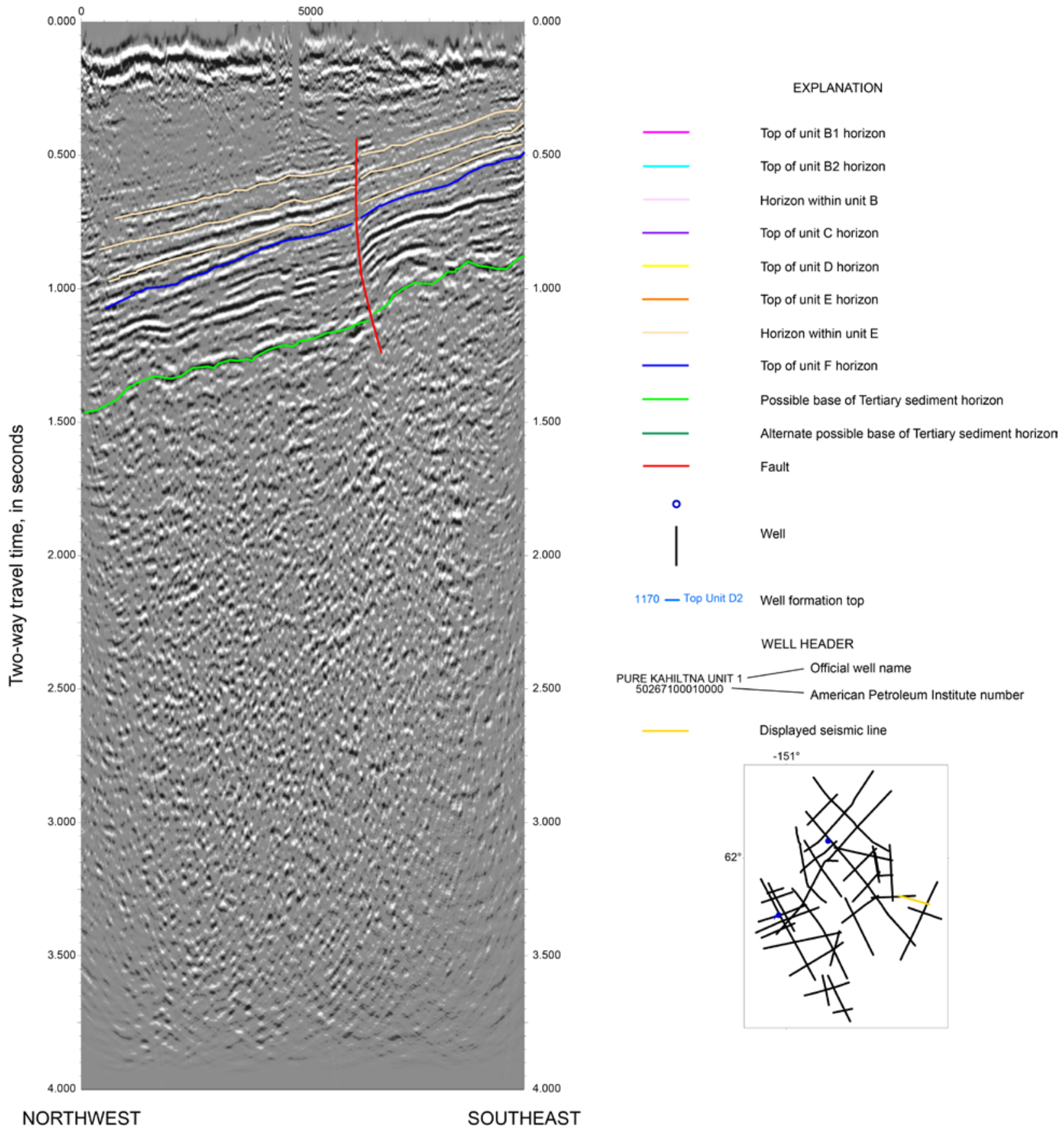

Figure 25. Seismic section 25 with interpretation. The horizontal axis is the offset along the line in meters, and the vertical axis is two-way travel time in seconds. Peaks (positive amplitudes) are black in the seismic section, while troughs (negative amplitudes) are white. The horizons shown correspond to units identified by Stanley and others $(2013,2014)$. Due to the intermittent low signal of the top unit $E$ horizon, additional horizons within unit $\mathrm{E}$ are also shown. Faults are shown in red. (Click here to open full-size, high-resolution image.) 


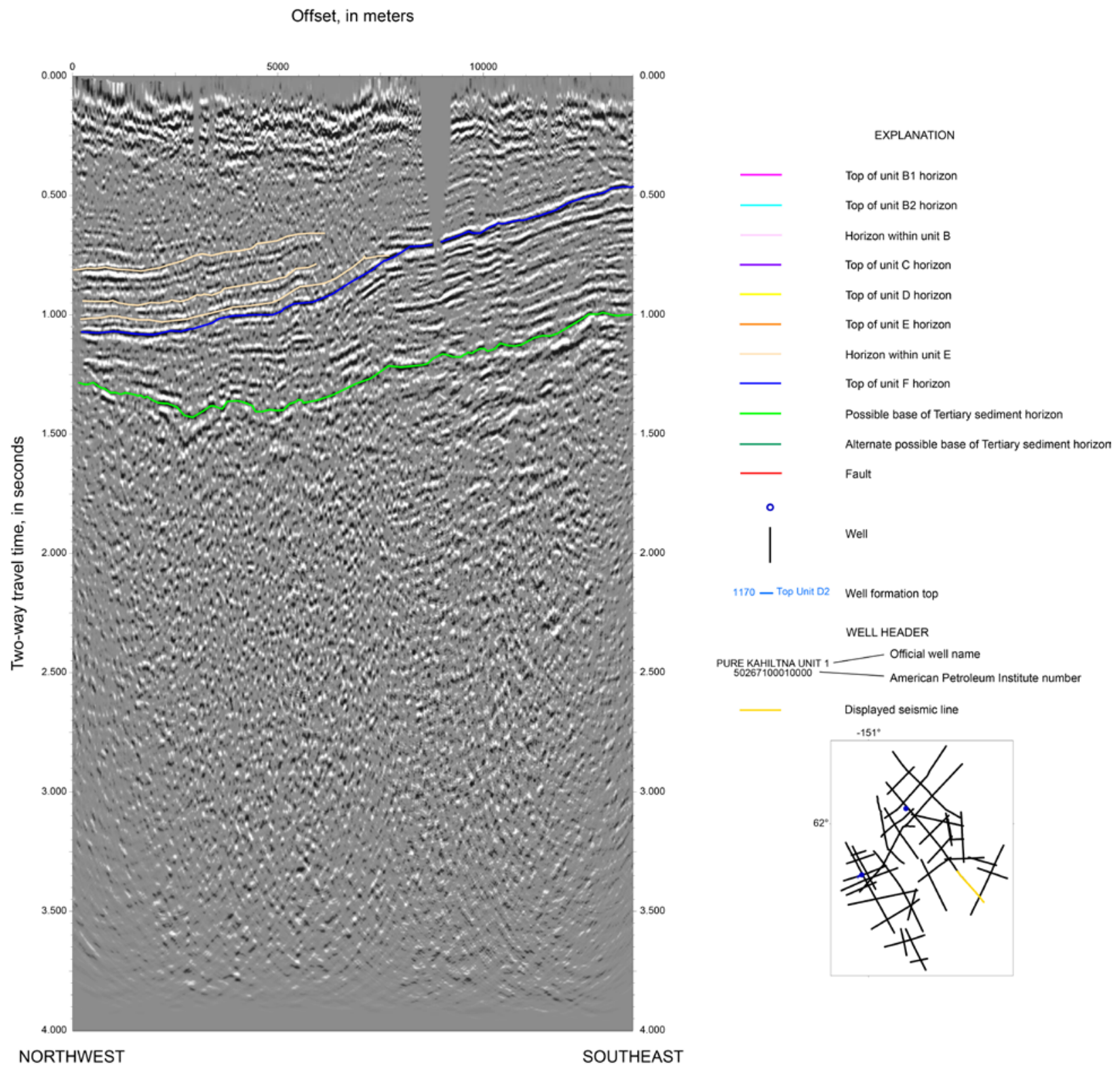

Figure 26. Seismic section 26 with interpretation. The horizontal axis is the offset along the line in meters, and the vertical axis is two-way travel time in seconds. Peaks (positive amplitudes) are black in the seismic section, while troughs (negative amplitudes) are white. The horizons shown correspond to units identified by Stanley and others $(2013,2014)$. Due to the intermittent low signal of the top unit $E$ horizon, additional horizons within unit $E$ are also shown. Unit $E$ horizons possibly onlap onto the top unit $F$ horizon at offset 7,500 meters. (Click here to open full-size, high-resolution image.) 


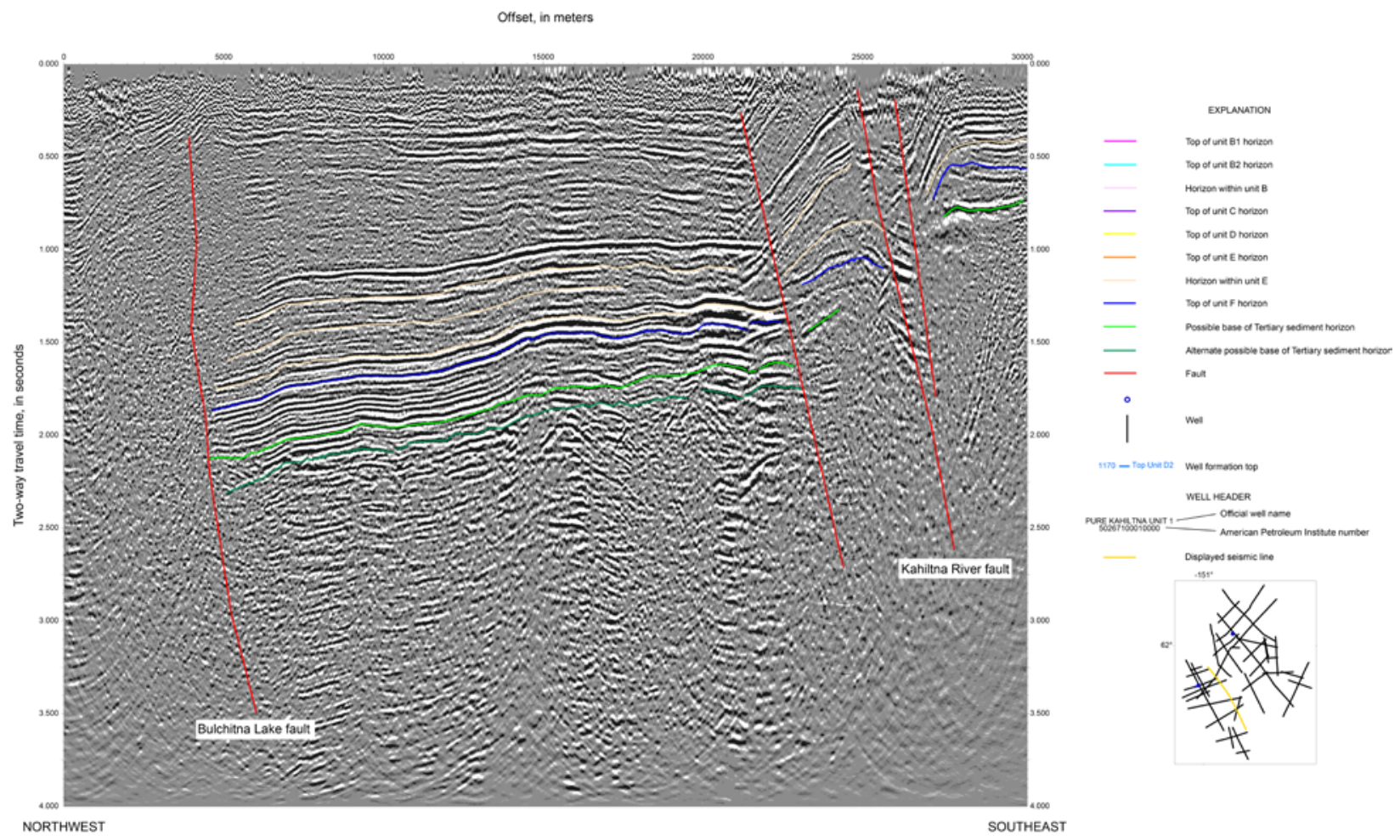

Figure 27. Seismic section 27 with interpretation. The horizontal axis is the offset along the line in meters, and the vertical axis is two-way travel time in seconds. Peaks (positive amplitudes) are black in the seismic section, while troughs (negative amplitudes) are white. The horizons shown correspond to units identified by Stanley and others $(2013,2014)$. Due to the intermittent low signal of the top unit $E$ horizon, additional horizons within unit $E$ are also shown. Faults are shown in red. (Click here to open full-size, high-resolution image.) 


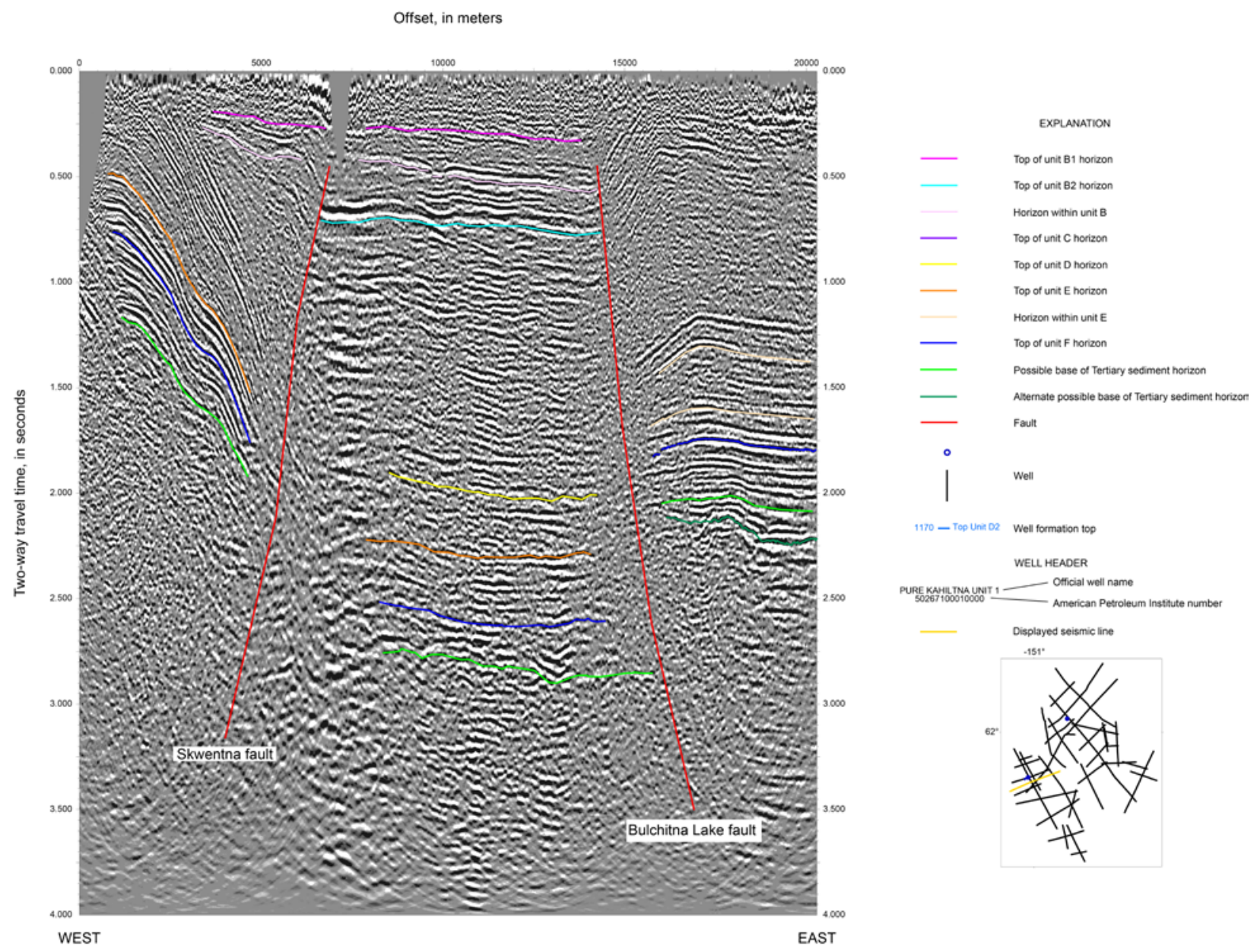

Figure 28. Seismic section 28 with interpretation. The horizontal axis is the offset along the line in meters, and the vertical axis is two-way travel time in seconds. Peaks (positive amplitudes) are black in the seismic section, while troughs (negative amplitudes) are white. The horizons shown correspond to units identified by Stanley and others $(2013,2014)$. Due to the intermittent low signal of the top unit $E$ horizon, additional horizons within unit $E$ are also shown. Faults are shown in red. Note the low-angle horizons that form a wedge shape above the steeply dipping horizons in the hanging wall block of the Skwentna fault. These low-angle horizons correlate to the B1 horizons. This implies that the wedge was progressively rotating during deposition, which, in turn, implies that the Skwentna fault was active during the deposition of unit B1. This would indicate that some of the displacement along the Skwentna fault is late Miocene and younger (Stanley and others, 2013, 2014). (Click here to open full-size, highresolution image.) 


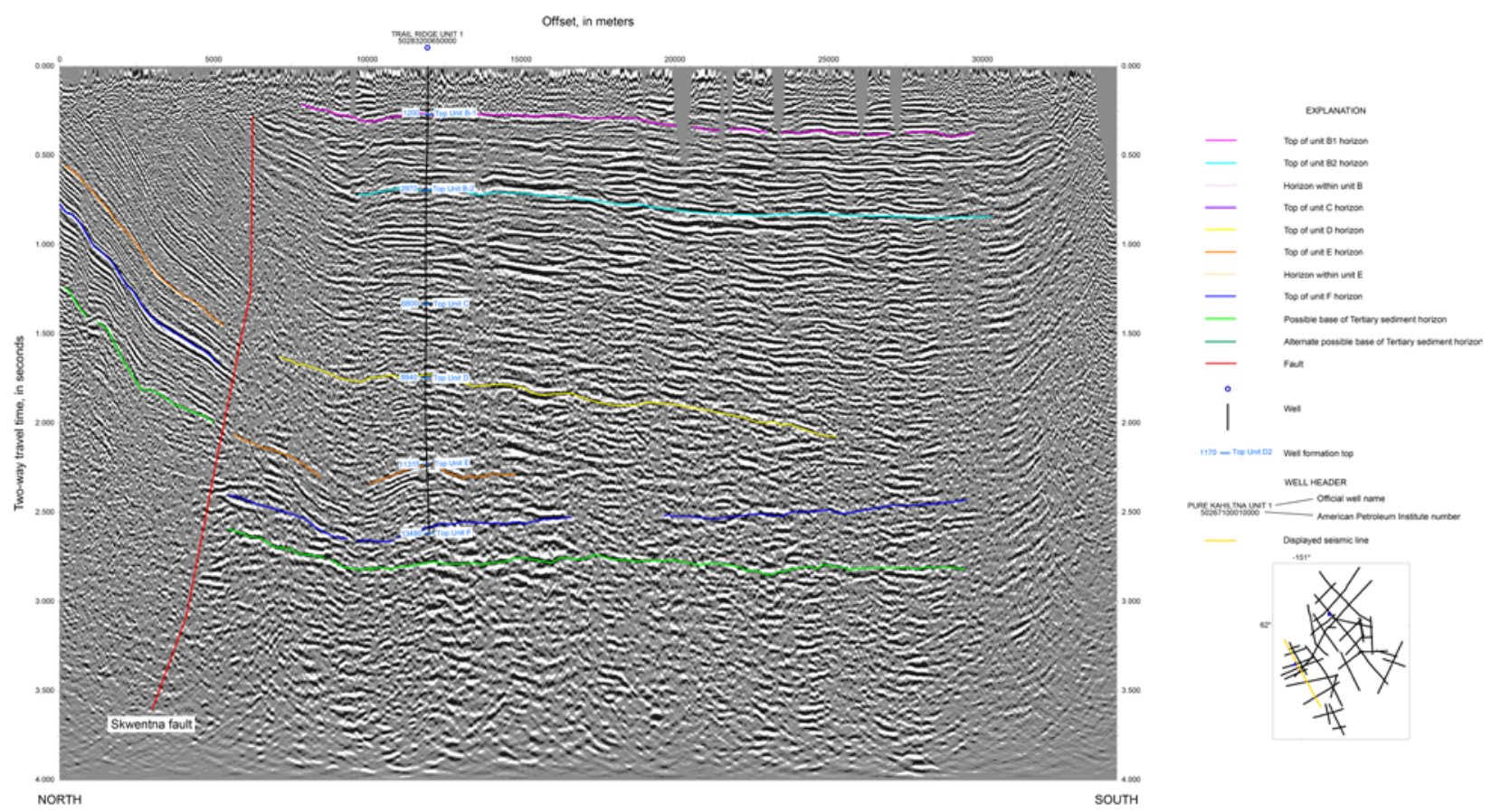

Figure 29. Seismic section 29 with interpretation. The horizontal axis is the offset along the line in meters, and the vertical axis is two-way travel time in seconds. Peaks (positive amplitudes) are black in the seismic section, while troughs (negative amplitudes) are white. The horizons shown correspond to units identified by Stanley and others $(2013,2014)$. Due to the intermittent low signal of the top unit $E$ horizon, additional horizons within unit $\mathrm{E}$ are also shown. Faults are shown in red. The Trail Ridge Unit 1 exploratory well is also displayed on this line. (Click here to open full-size, high-resolution image.) 


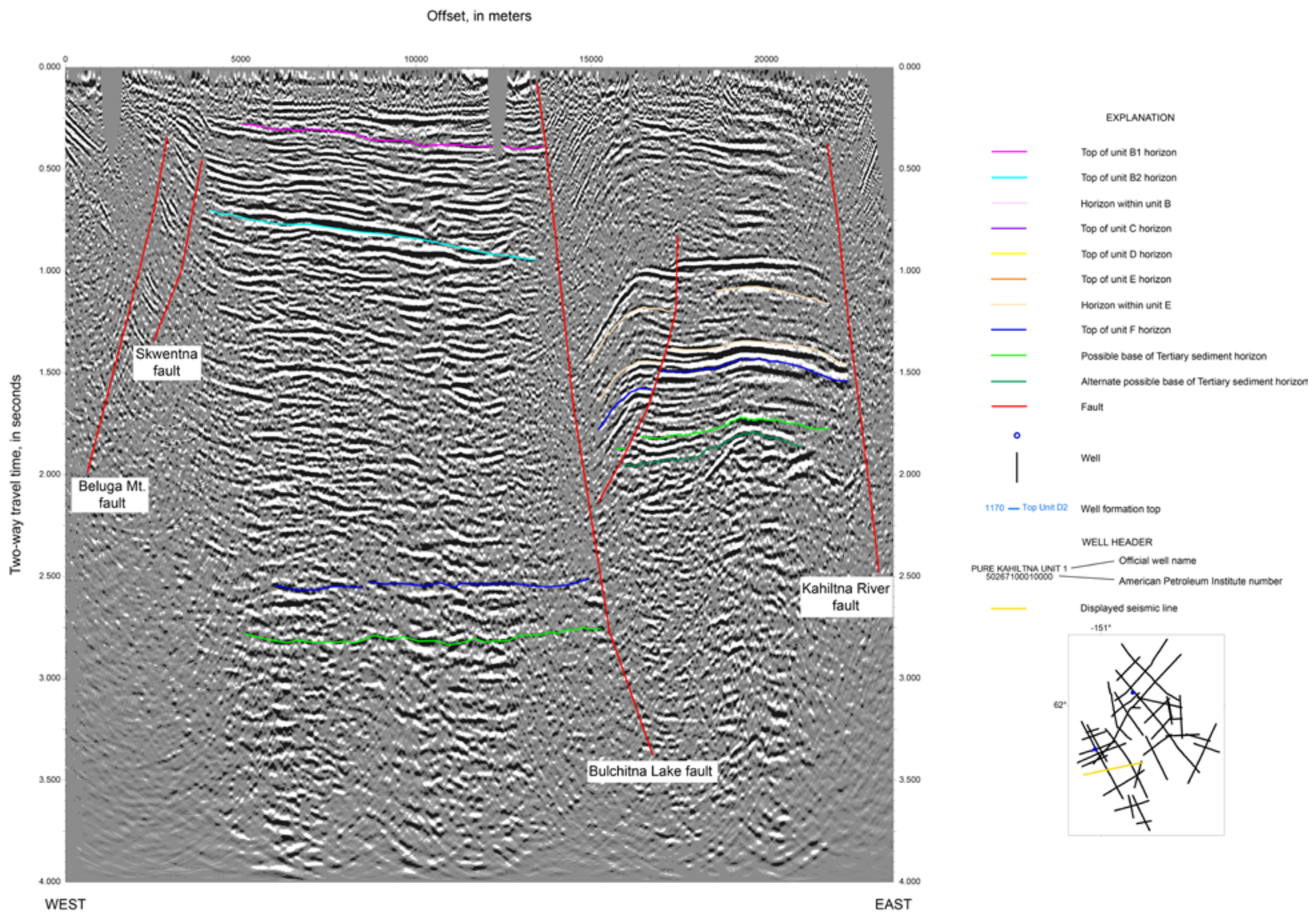

Figure 30. Seismic section 30 with interpretation. The horizontal axis is the offset along the line in meters, and the vertical axis is two-way travel time in seconds. Peaks (positive amplitudes) are black in the seismic section, while troughs (negative amplitudes) are white. The horizons shown correspond to units identified by Stanley and others $(2013,2014)$. Due to the intermittent low signal of the top unit $E$ horizon, additional horizons within unit $\mathrm{E}$ are also shown. Faults are shown in red. (Click here to open full-size, high-resolution image.) 


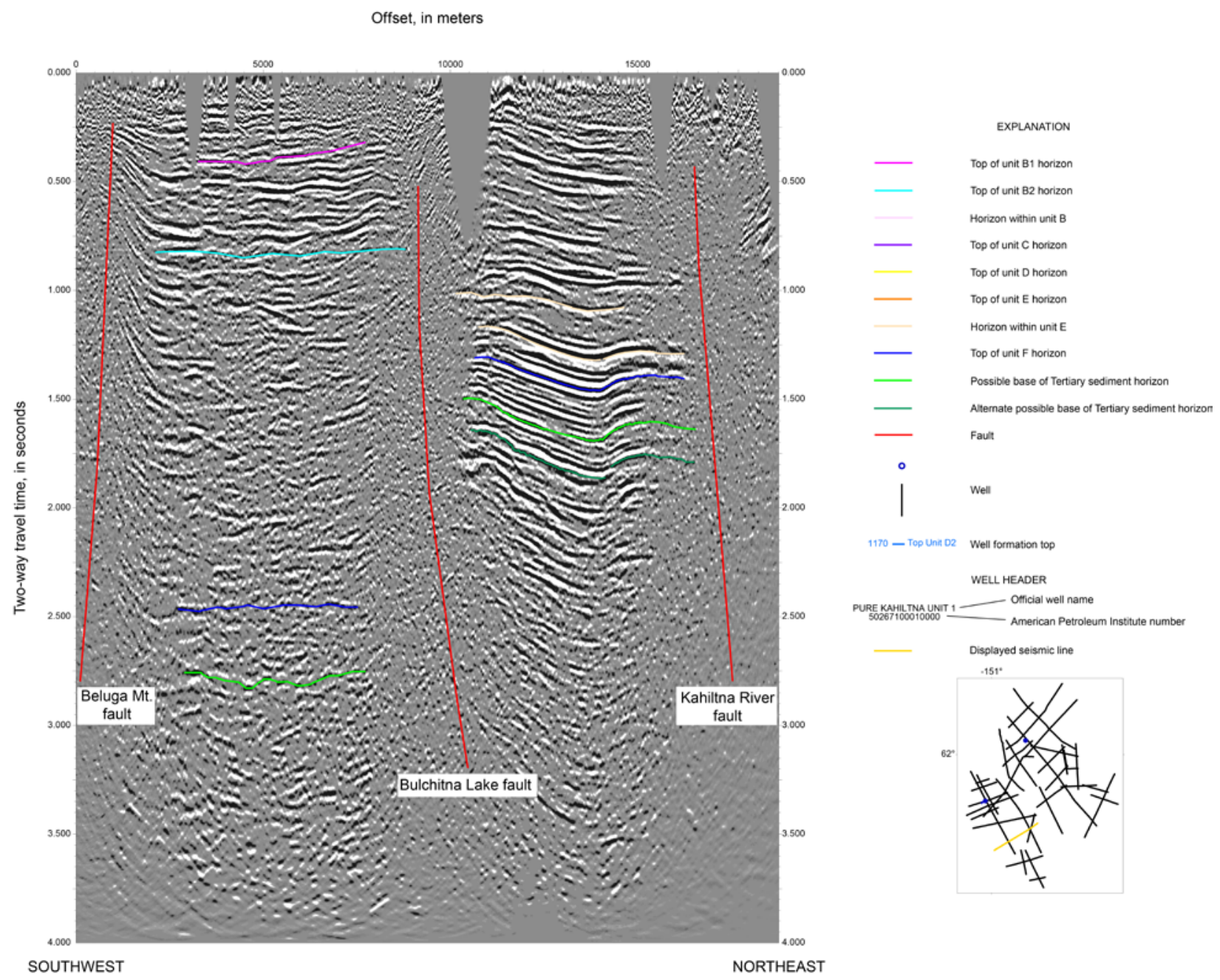

Figure 31. Seismic section 31 with interpretation. The horizontal axis is the offset along the line in meters, and the vertical axis is two-way travel time in seconds. Peaks (positive amplitudes) are black in the seismic section, while troughs (negative amplitudes) are white. The horizons shown correspond to units identified by Stanley and others $(2013,2014)$. Due to the intermittent low signal of the top unit $E$ horizon, additional horizons within unit $\mathrm{E}$ are also shown. Faults are shown in red. (Click here to open full-size, high-resolution image.) 
Offset, in meters

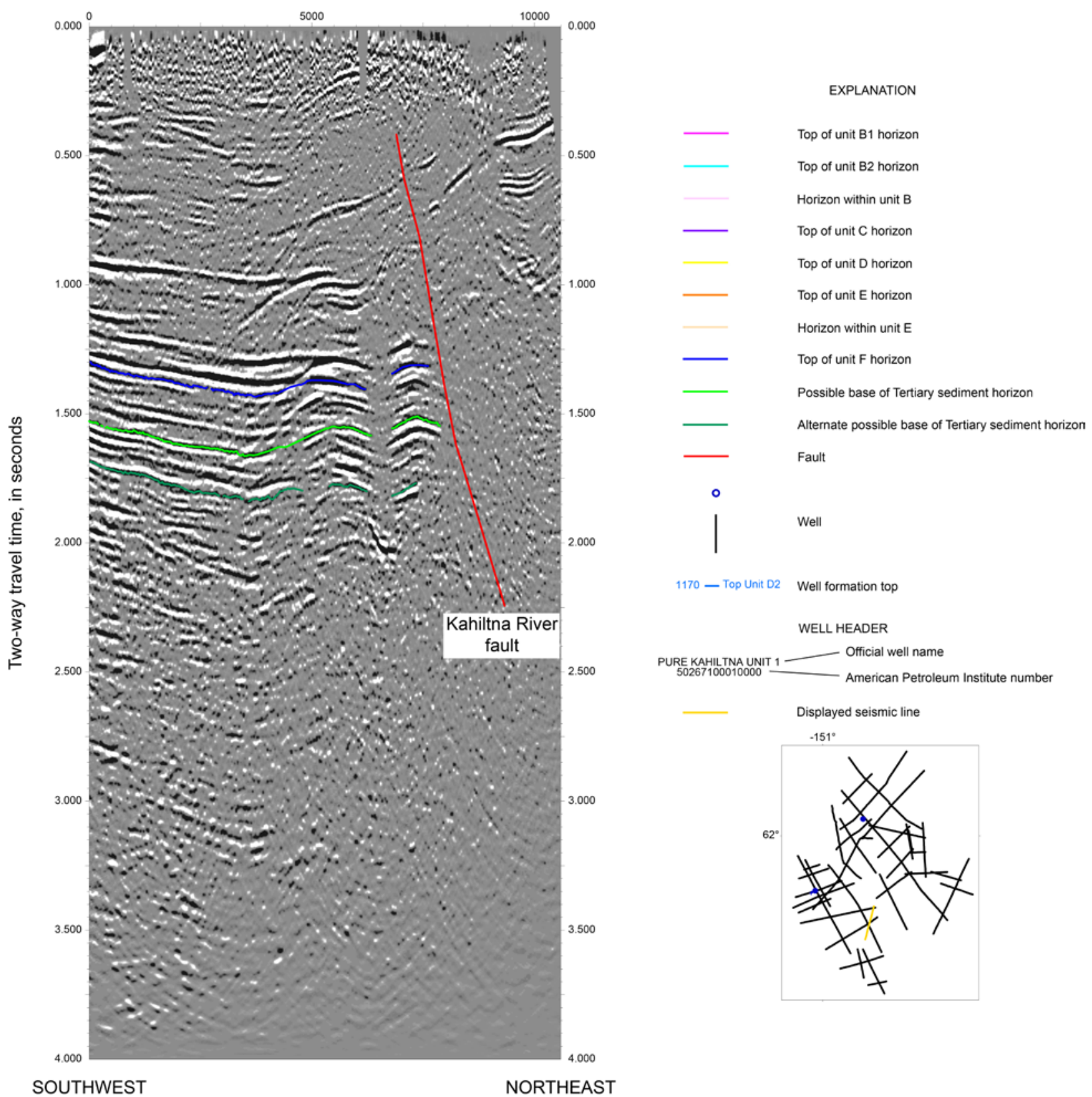

Figure 32. Seismic section 32 with interpretation. The horizontal axis is the offset along the line in meters, and the vertical axis is two-way travel time in seconds. Peaks (positive amplitudes) are black in the seismic section, while troughs (negative amplitudes) are white. The horizons shown correspond to units identified by Stanley and others $(2013,2014)$. Due to the intermittent low signal of the top unit $E$ horizon, additional horizons within unit $\mathrm{E}$ are also shown. Faults are shown in red. (Click here to open full-size, high-resolution image.) 


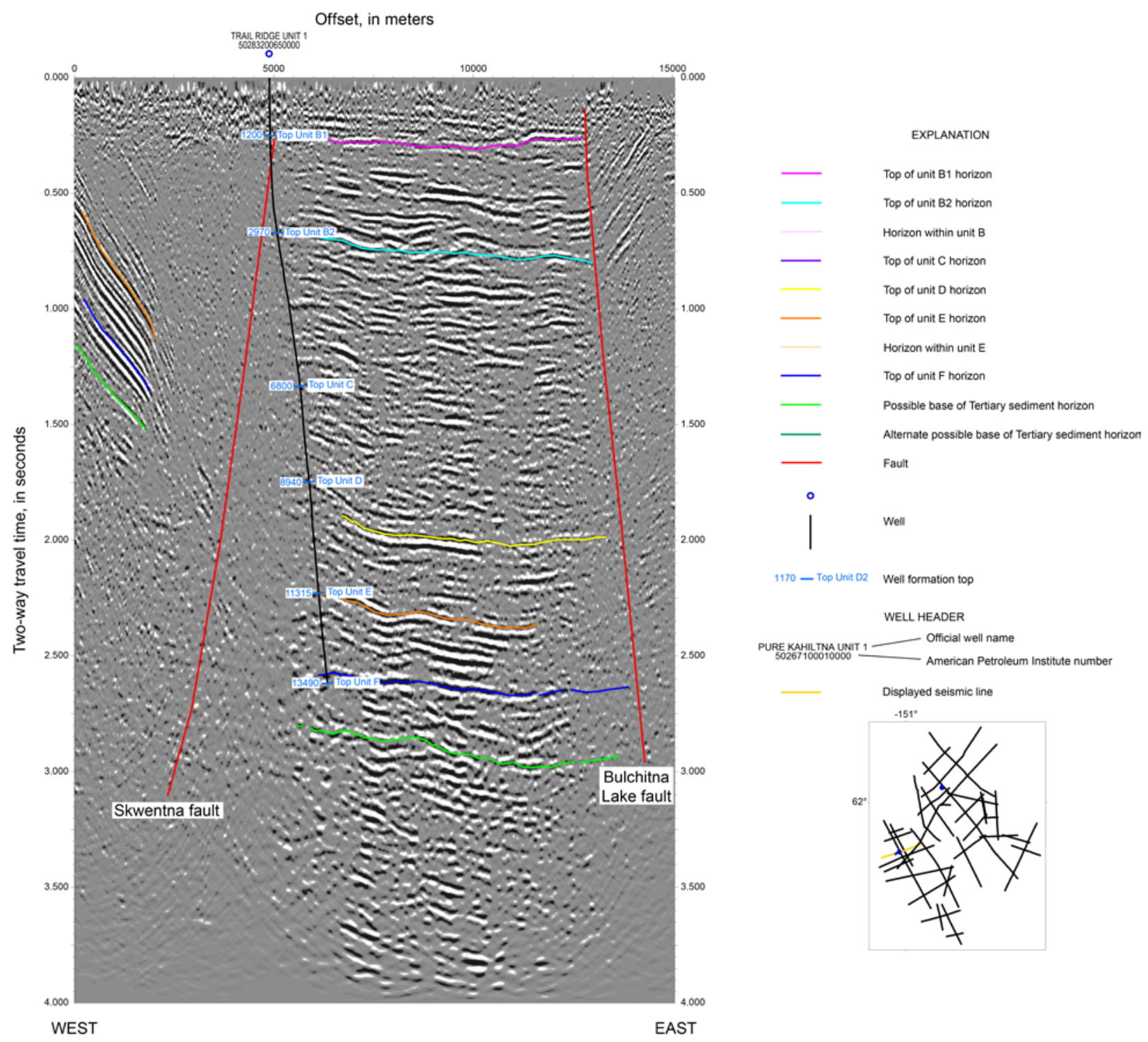

Figure 33. Seismic section 33 with interpretation. The horizontal axis is the offset along the line in meters, and the vertical axis is two-way travel time in seconds. Peaks (positive amplitudes) are black in the seismic section, while troughs (negative amplitudes) are white. The horizons shown correspond to units identified by Stanley and others $(2013,2014)$. Due to the intermittent low signal of the top unit $E$ horizon, additional horizons within unit $E$ are also shown. Faults are shown in red. The Trail Ridge Unit 1 exploratory well is also displayed on this line. (Click here to open full-size, high-resolution image.) 
Offset, in meters

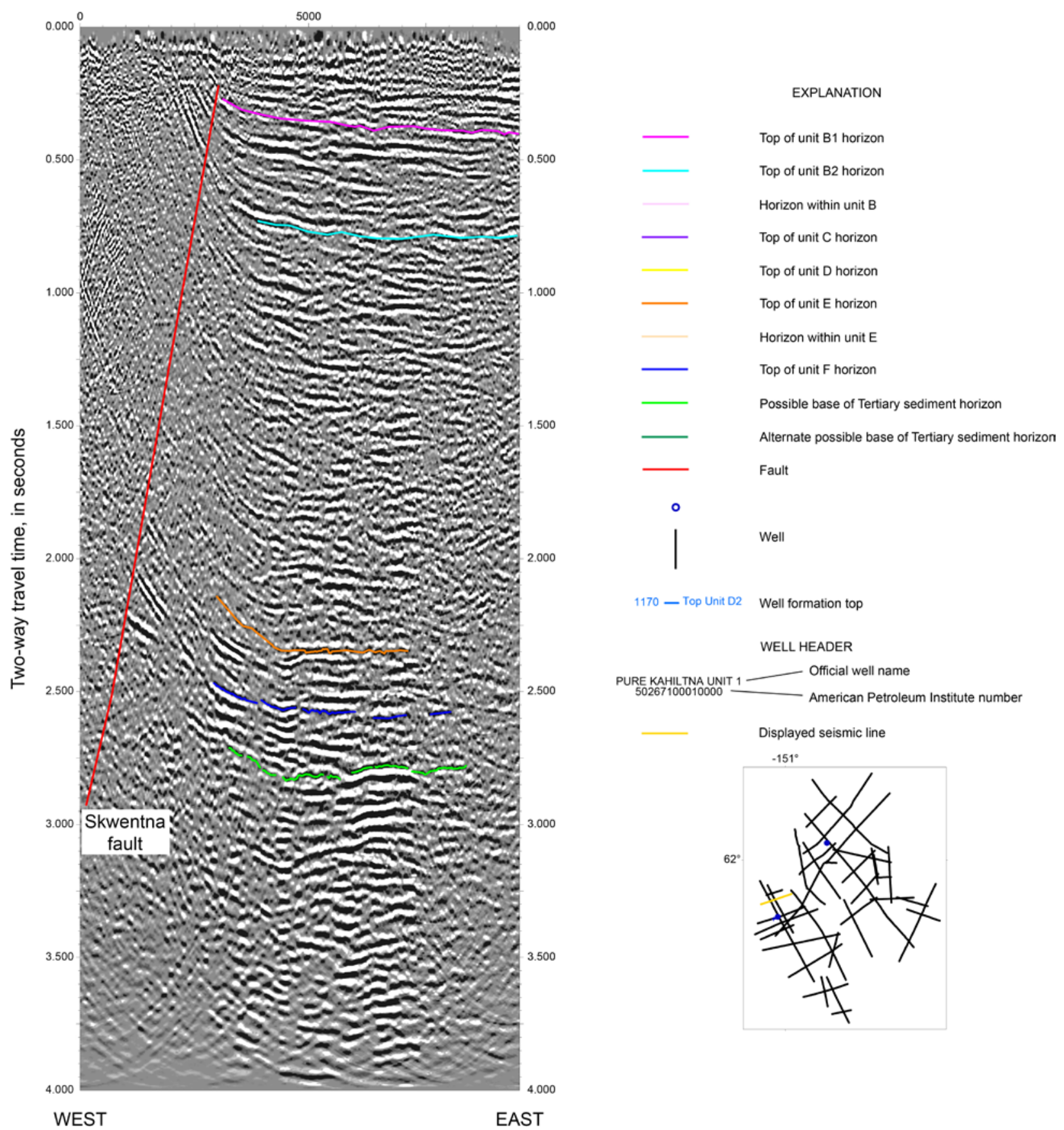

Figure 34. Seismic section 34 with interpretation. The horizontal axis is the offset along the line in meters, and the vertical axis is two-way travel time in seconds. Peaks (positive amplitudes) are black in the seismic section, while troughs (negative amplitudes) are white. The horizons shown correspond to units identified by Stanley and others $(2013,2014)$. Due to the intermittent low signal of the top unit $E$ horizon, additional horizons within unit $\mathrm{E}$ are also shown. Faults are shown in red. (Click here to open full-size, high-resolution image.) 


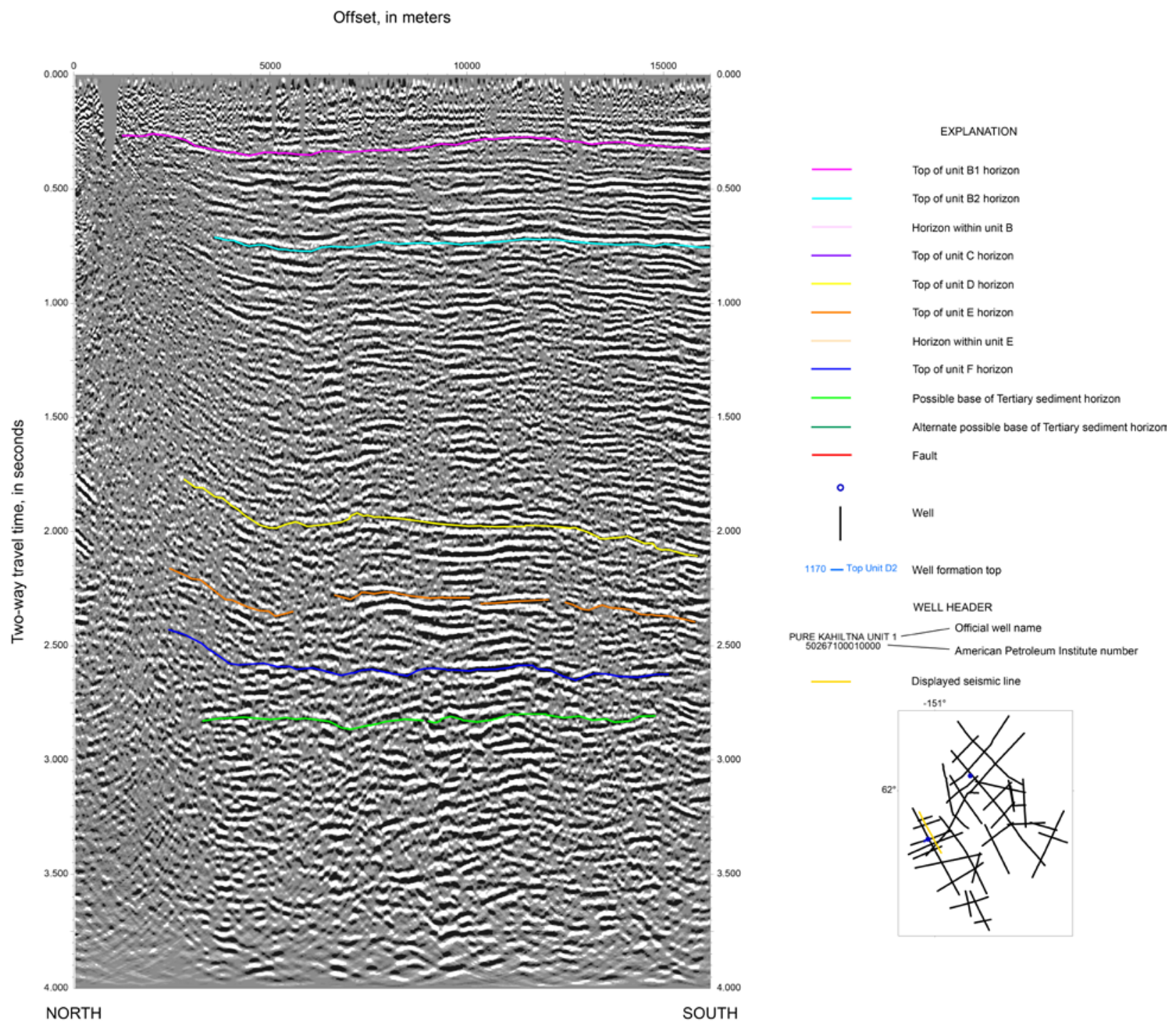

Figure 35. Seismic section 35 with interpretation. The horizontal axis is the offset along the line in meters, and the vertical axis is two-way travel time in seconds. Peaks (positive amplitudes) are black in the seismic section, while troughs (negative amplitudes) are white. The horizons shown correspond to units identified by Stanley and others $(2013,2014)$. Due to the intermittent low signal of the top unit $E$ horizon, additional horizons within unit $\mathrm{E}$ are also shown. (Click here to open full-size, high-resolution image.) 


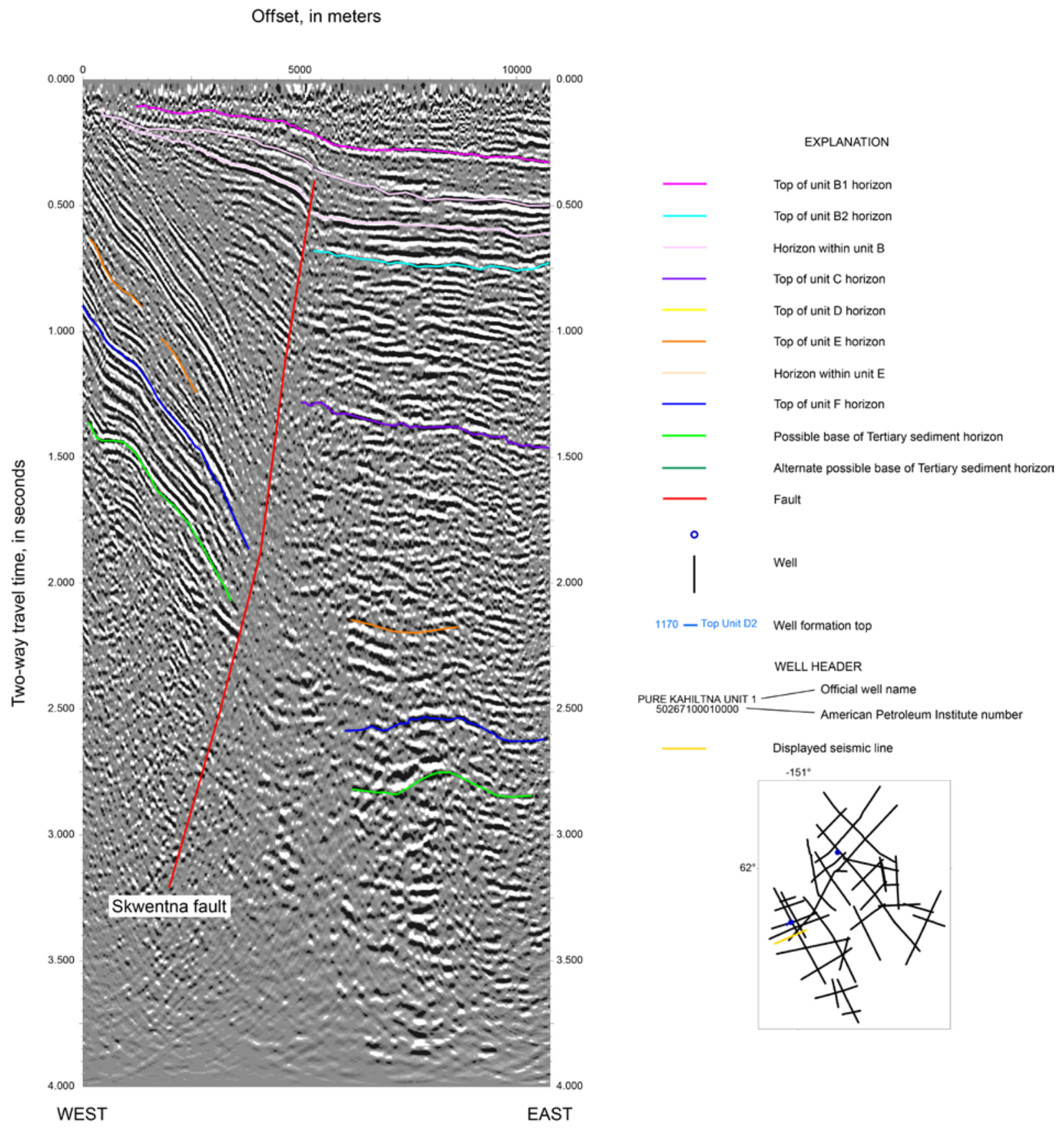

Figure 36. Seismic section 36 with interpretation. The horizontal axis is the offset along the line in meters, and the vertical axis is two-way travel time in seconds. Peaks (positive amplitudes) are black in the seismic section, while troughs (negative amplitudes) are white. The horizons shown correspond to units identified by Stanley and others $(2013,2014)$. Due to the intermittent low signal of the top unit $E$ horizon, additional horizons within unit $E$ are also shown. Faults are shown in red. Note the low-angle horizons that form a wedge shape above the steeply dipping horizons in the hanging wall block of the Skwentna fault. These low-angle horizons correlate to the B1 horizons. This wedge of material is the same as seen in figure 28. Again, this implies that the displacement along the Skwentna fault is late Miocene and younger (Stanley and others, 2013, 2014). See figure 28 for further explanation. (Click here to open full-size, high-resolution image.) 
Offset, in meters

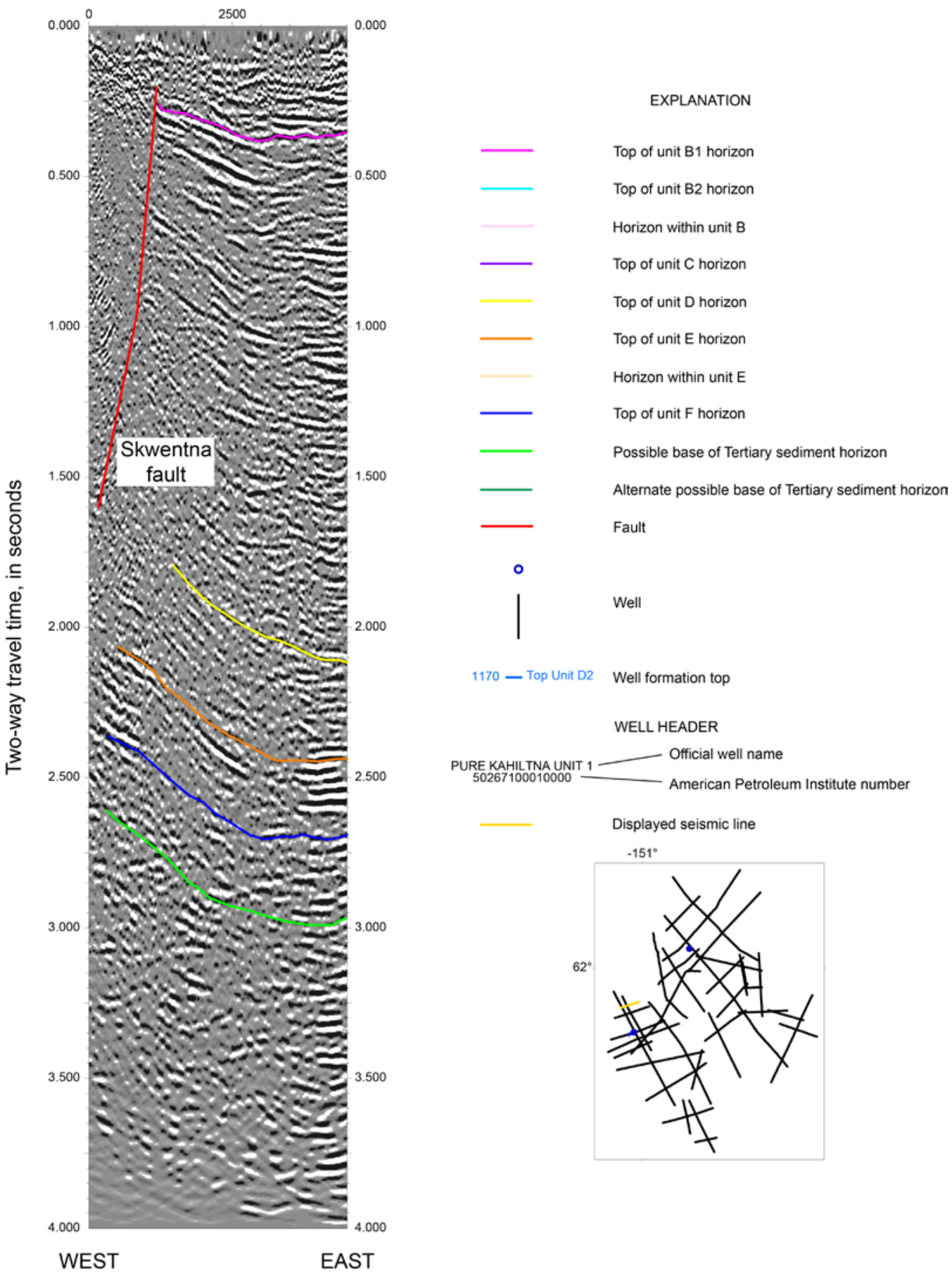

Figure 37. Seismic section 37 with interpretation. The horizontal axis is the offset along the line in meters, and the vertical axis is two-way travel time in seconds. Peaks (positive amplitudes) are black in the seismic section, while troughs (negative amplitudes) are white. The horizons shown correspond to units identified by Stanley and others $(2013,2014)$. Due to the intermittent low signal of the top unit $E$ horizon, additional horizons within unit $\mathrm{E}$ are also shown. Faults are shown in red. (Click here to open full-size, high-resolution image.) 


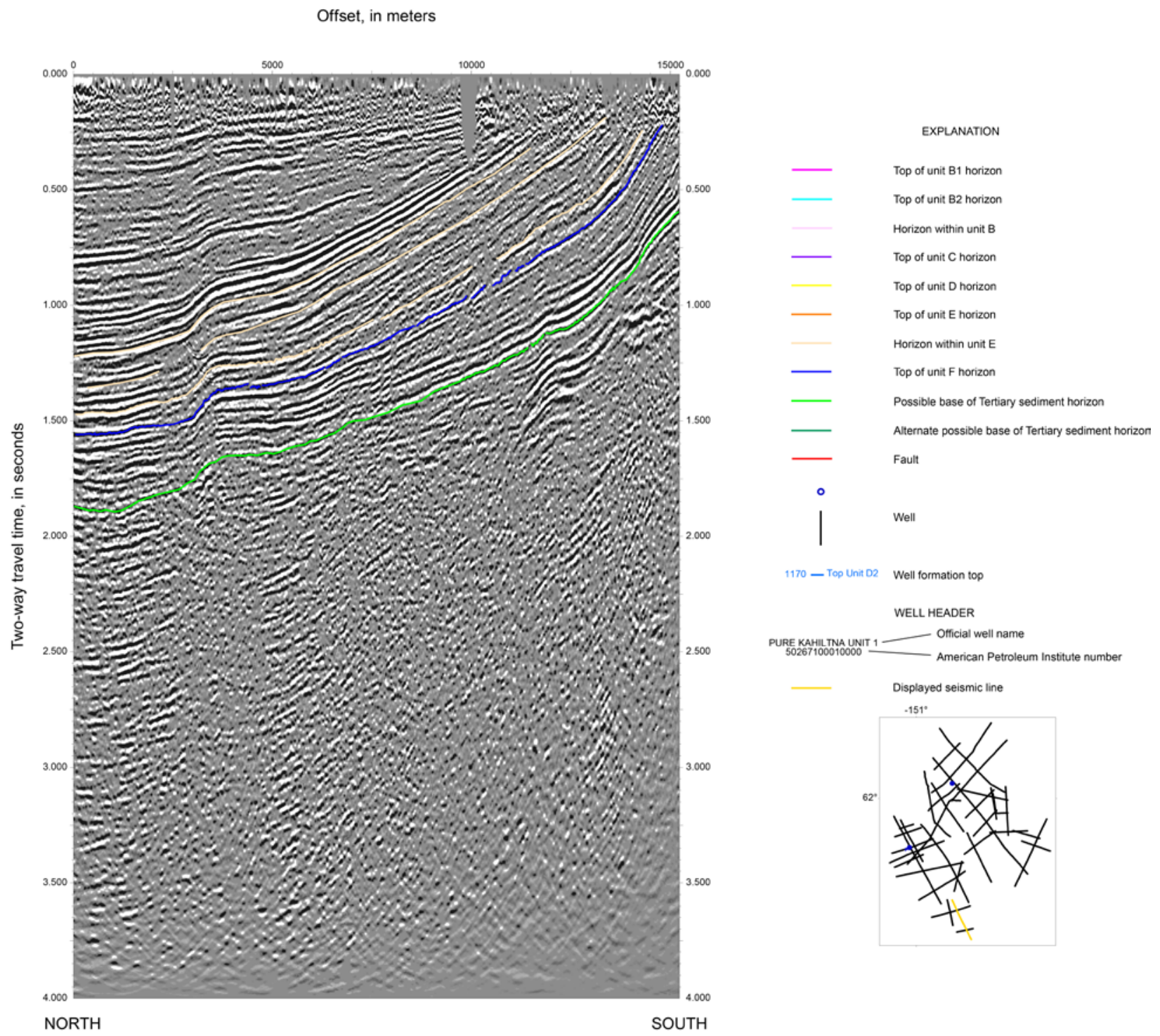

Figure 38. Seismic section 38 with interpretation. The horizontal axis is the offset along the line in meters, and the vertical axis is two-way travel time in seconds. Peaks (positive amplitudes) are black in the seismic section, while troughs (negative amplitudes) are white. The horizons shown correspond to units identified by Stanley and others $(2013,2014)$. Due to the intermittent low signal of the top unit $E$ horizon, additional horizons within unit $\mathrm{E}$ are also shown. (Click here to open full-size, high-resolution image.) 


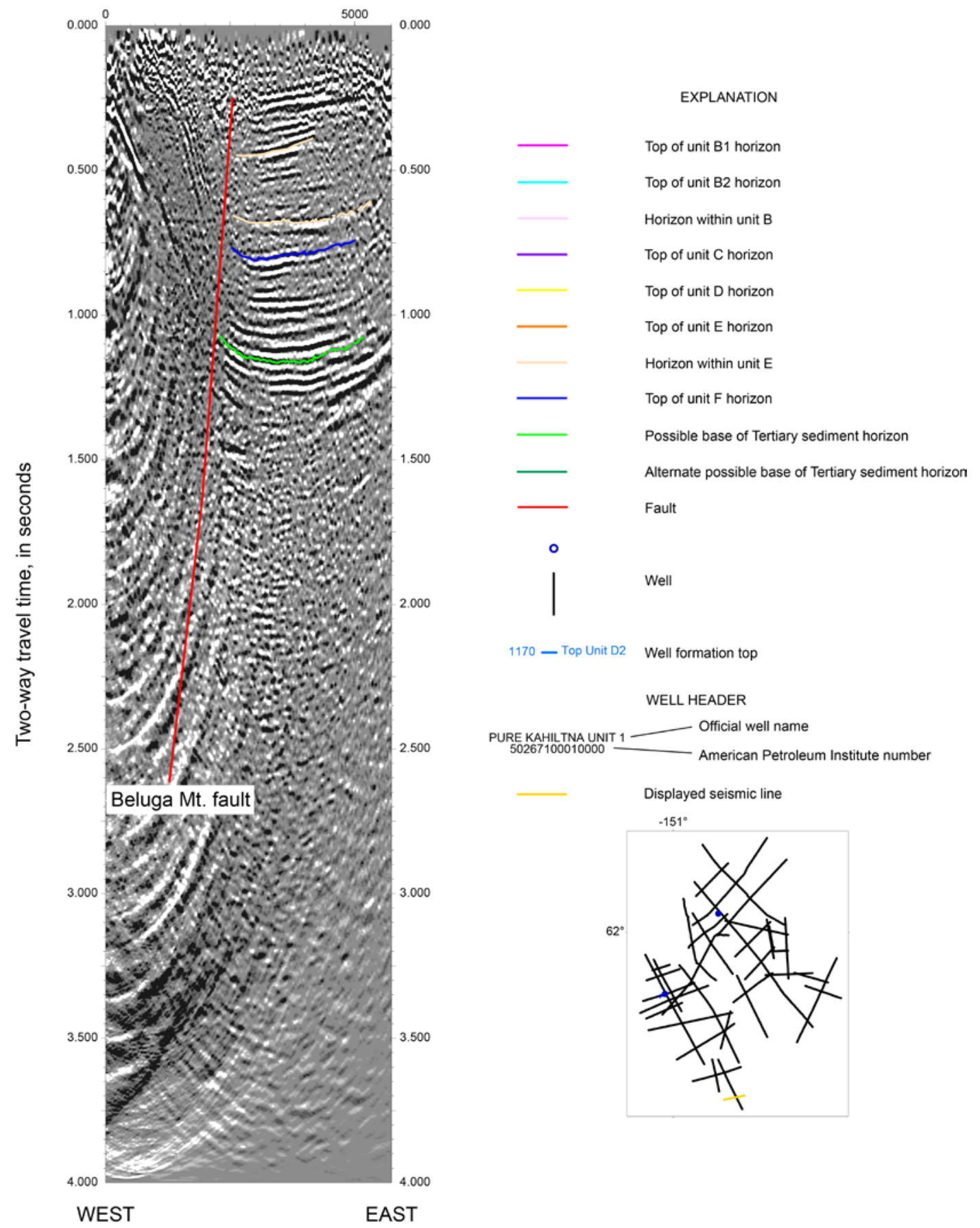

Figure 39. Seismic section 39 with interpretation. The horizontal axis is the offset along the line in meters, and the vertical axis is two-way travel time in seconds. Peaks (positive amplitudes) are black in the seismic section, while troughs (negative amplitudes) are white. The horizons shown correspond to units identified by Stanley and others $(2013,2014)$. Due to the intermittent low signal of the top unit $E$ horizon, additional horizons within unit $\mathrm{E}$ are also shown. Faults are shown in red. This line is heavily affected by migration artifacts. (Click here to open full-size, high-resolution image.) 


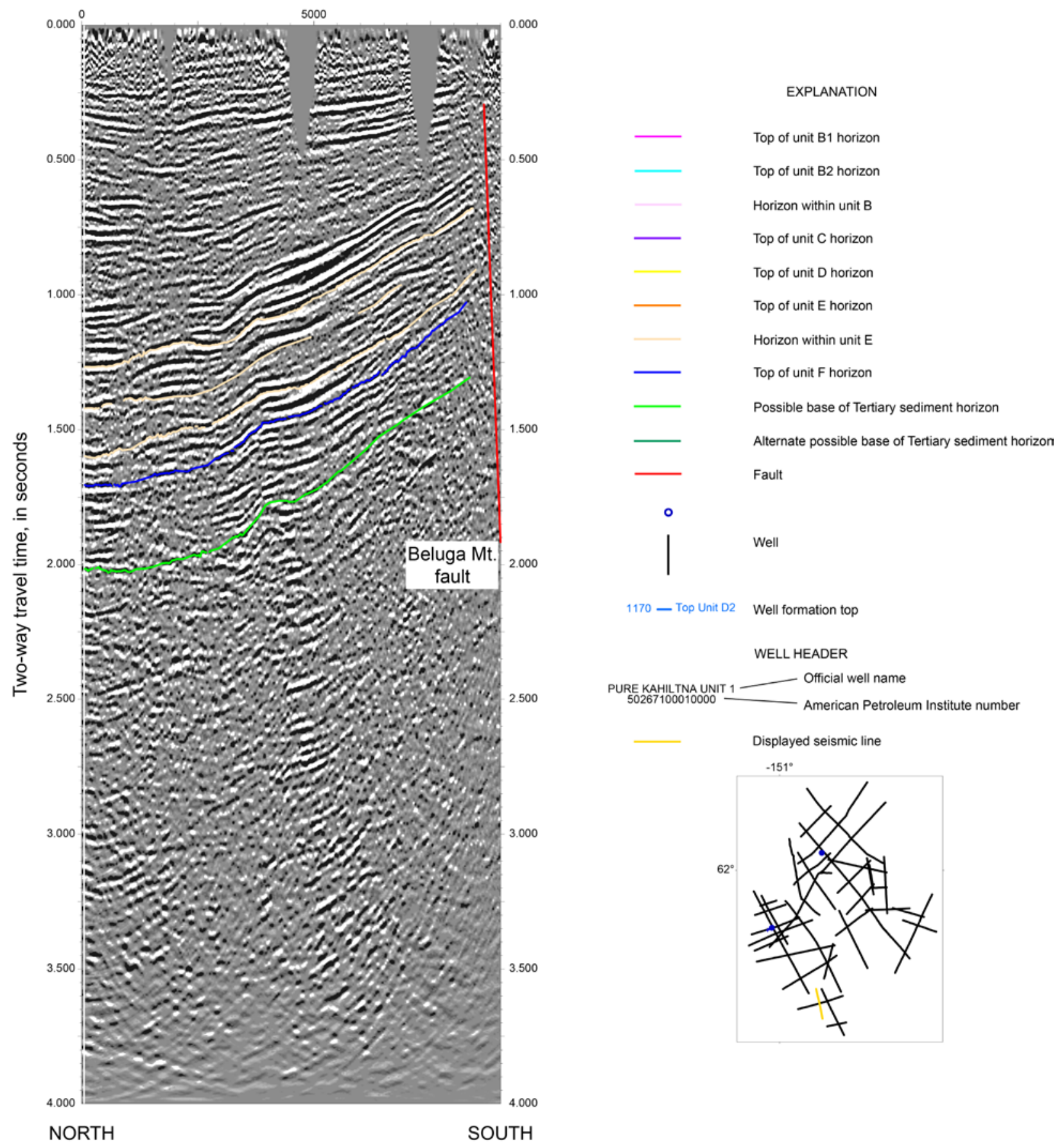

Figure 40. Seismic section 40 with interpretation. The horizontal axis is the offset along the line in meters, and the vertical axis is two-way travel time in seconds. Peaks (positive amplitudes) are black in the seismic section, while troughs (negative amplitudes) are white. The horizons shown correspond to units identified by Stanley and others $(2013,2014)$. Due to the intermittent low signal of the top unit $E$ horizon, additional horizons within unit $\mathrm{E}$ are also shown. Faults are shown in red. (Click here to open full-size, high-resolution image.) 


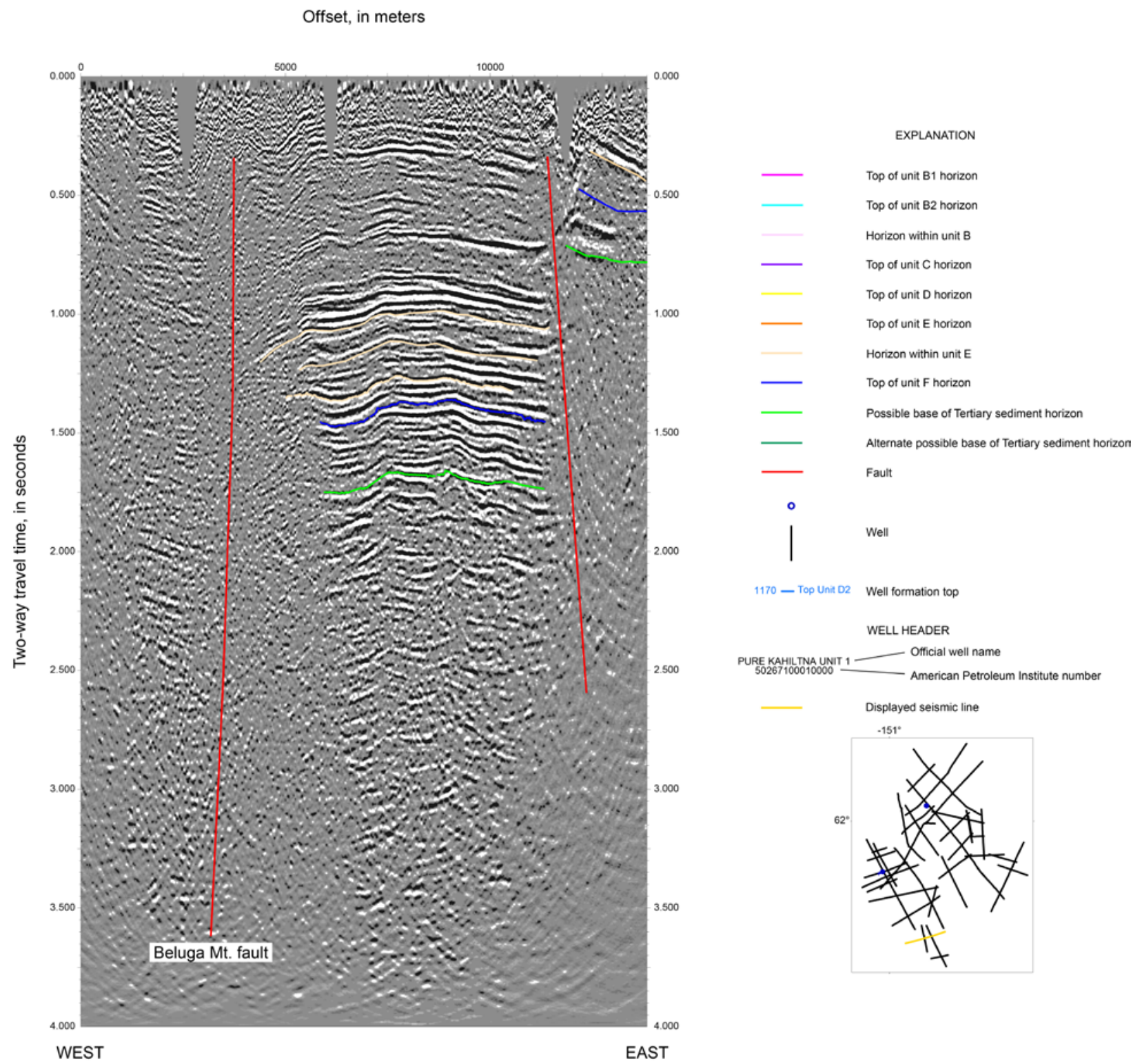

Figure 41. Seismic section 41 with interpretation. The horizontal axis is the offset along the line in meters, and the vertical axis is two-way travel time in seconds. Peaks (positive amplitudes) are black in the seismic section, while troughs (negative amplitudes) are white. The horizons shown correspond to units identified by Stanley and others $(2013,2014)$. Due to the intermittent low signal of the top unit $E$ horizon, additional horizons within unit $E$ are also shown. Faults are shown in red. (Click here to open full-size, high-resolution image.) 


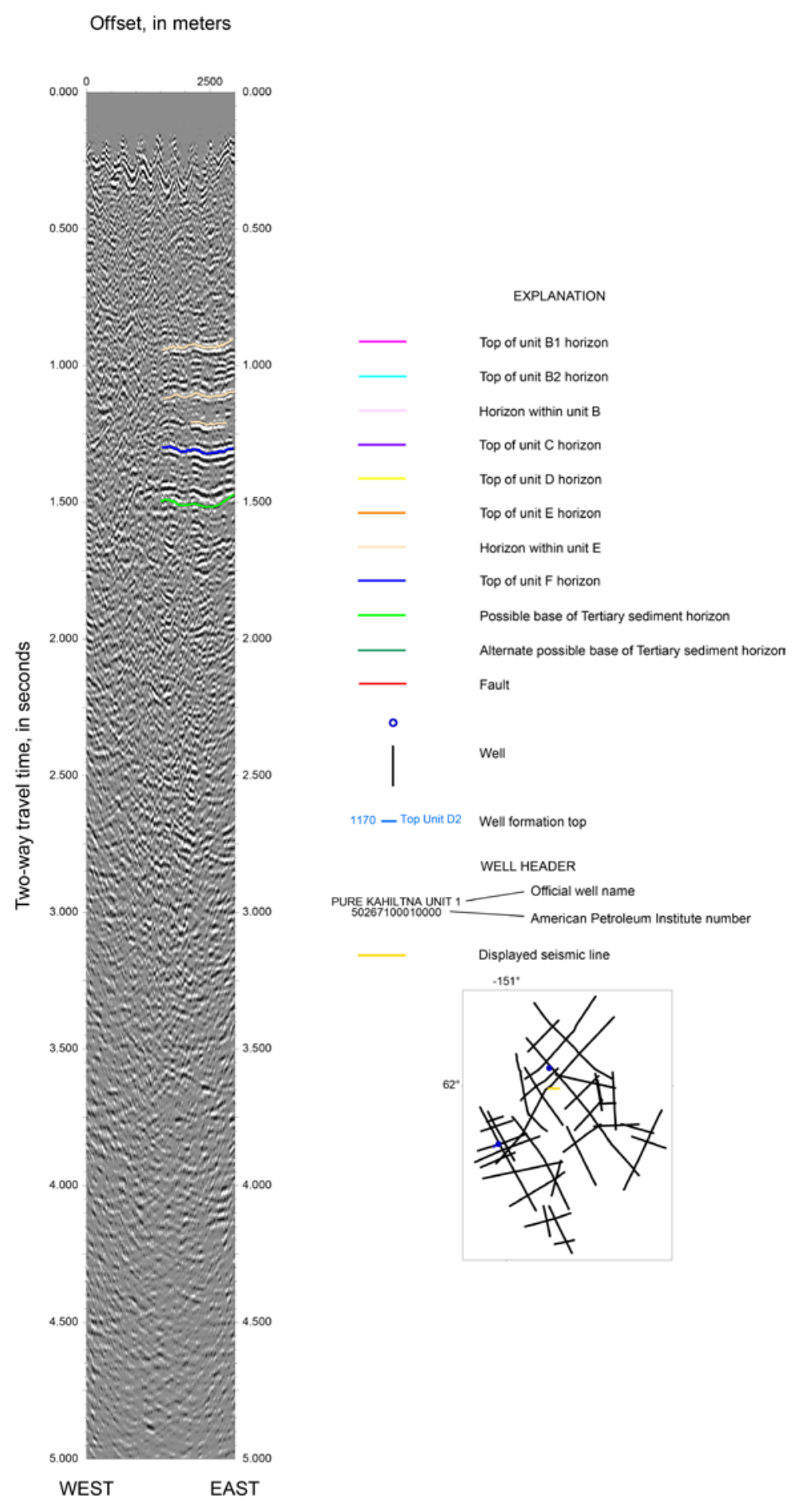

Figure 42. Seismic section 42 with interpretation. The horizontal axis is the offset along the line in meters, and the vertical axis is two-way travel time in seconds. Peaks (positive amplitudes) are black in the seismic section, while troughs (negative amplitudes) are white. The horizons shown correspond to units identified by Stanley and others $(2013,2014)$. Due to the intermittent low signal of the top unit $E$ horizon, additional horizons within unit $\mathrm{E}$ are also shown. (Click here to open full-size, high-resolution image.) 


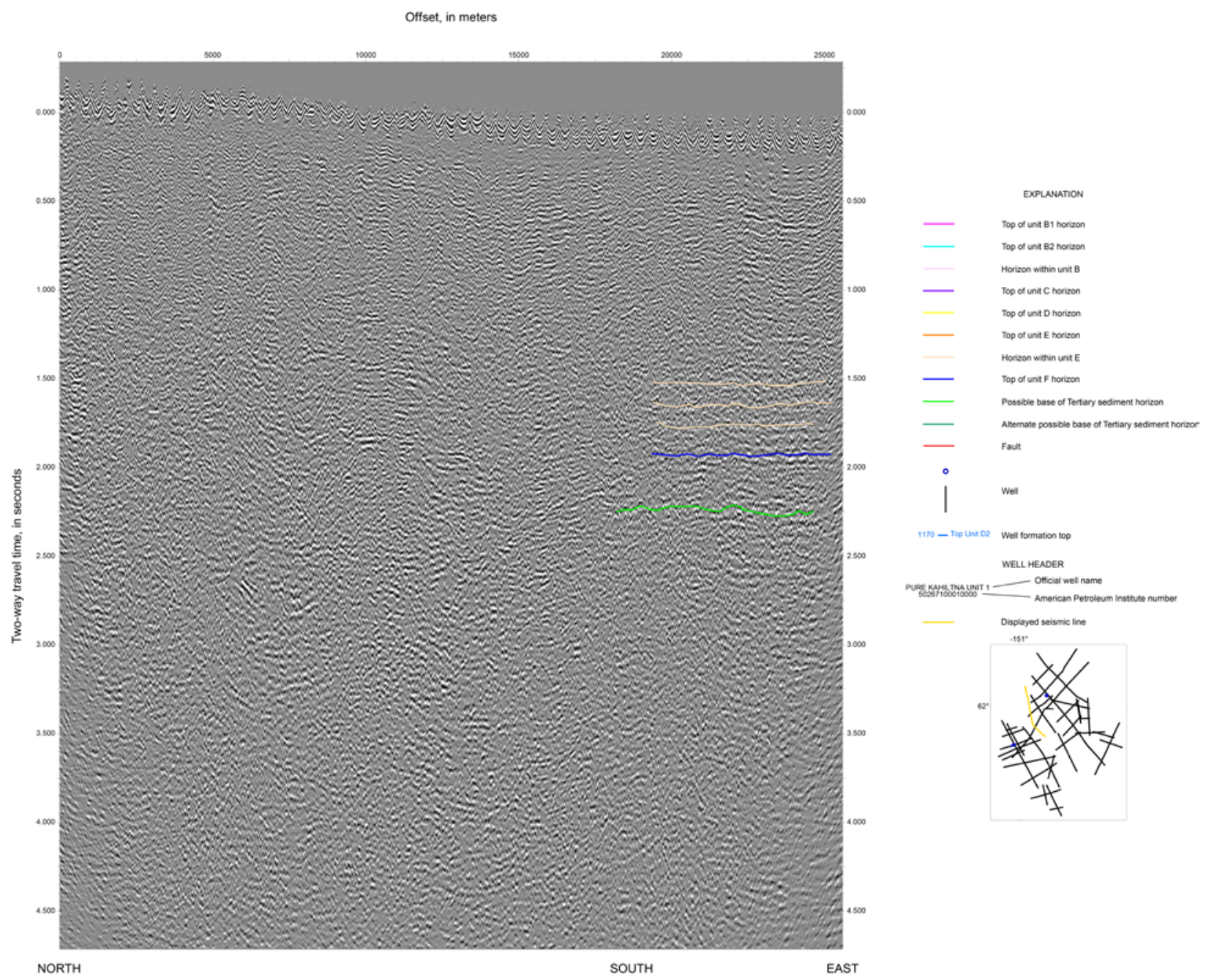

Figure 43. Seismic section 43 with interpretation. The horizontal axis is the offset along the line in meters, and the vertical axis is two-way travel time in seconds. Peaks (positive amplitudes) are black in the seismic section, while troughs (negative amplitudes) are white. The horizons shown correspond to units identified by Stanley and others $(2013,2014)$. Due to the intermittent low signal of the top unit $E$ horizon, additional horizons within unit $\mathrm{E}$ are also shown. (Click here to open full-size, high-resolution image.) 


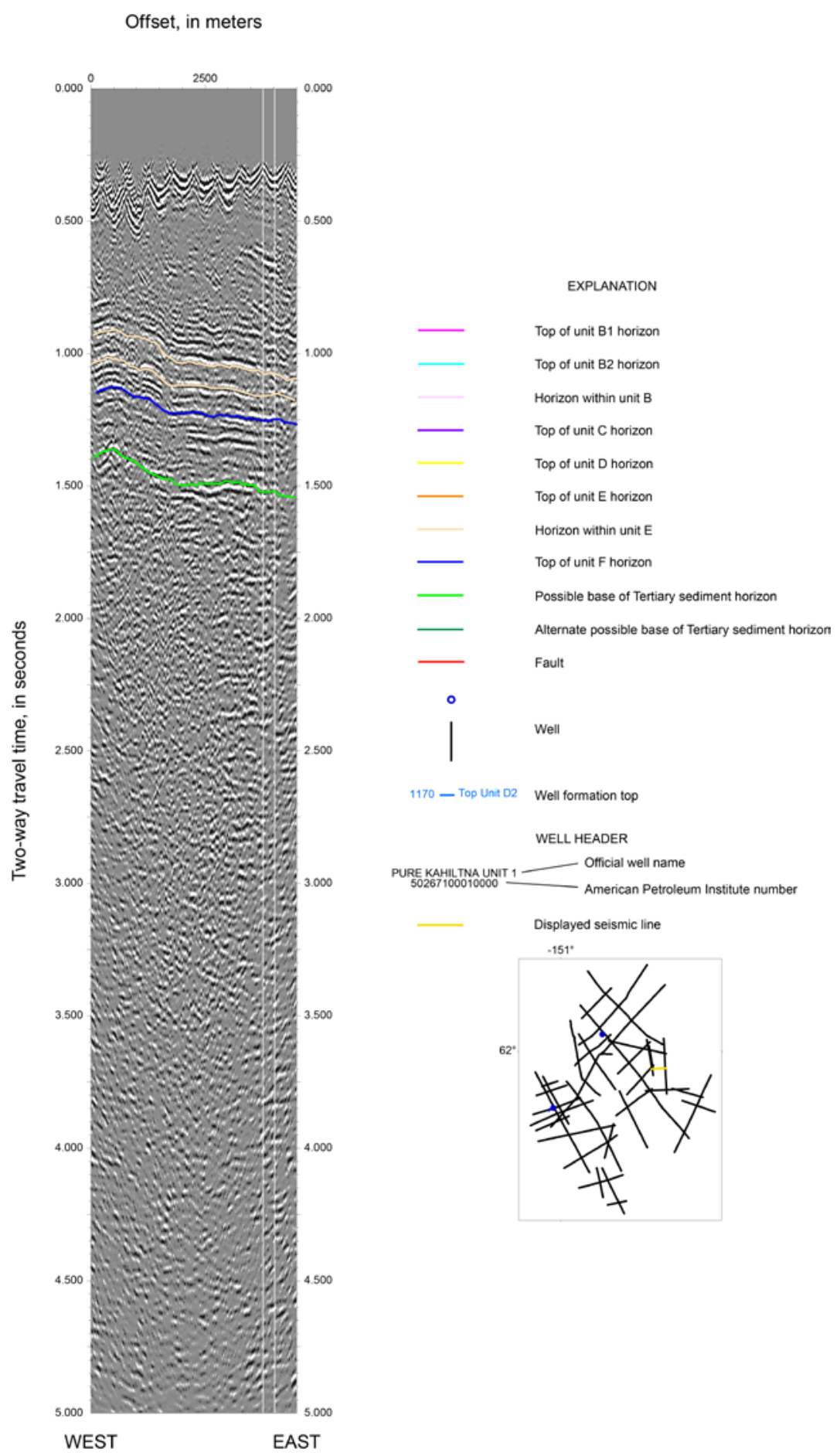

Figure 44. Seismic section 44 with interpretation. The horizontal axis is the offset along the line in meters, and the vertical axis is two-way travel time in seconds. Peaks (positive amplitudes) are black in the seismic section, while troughs (negative amplitudes) are white. The horizons shown correspond to units identified by Stanley and others $(2013,2014)$. Due to the intermittent low signal of the top unit $E$ horizon, additional horizons within unit $\mathrm{E}$ are also shown. (Click here to open full-size, high-resolution image.) 


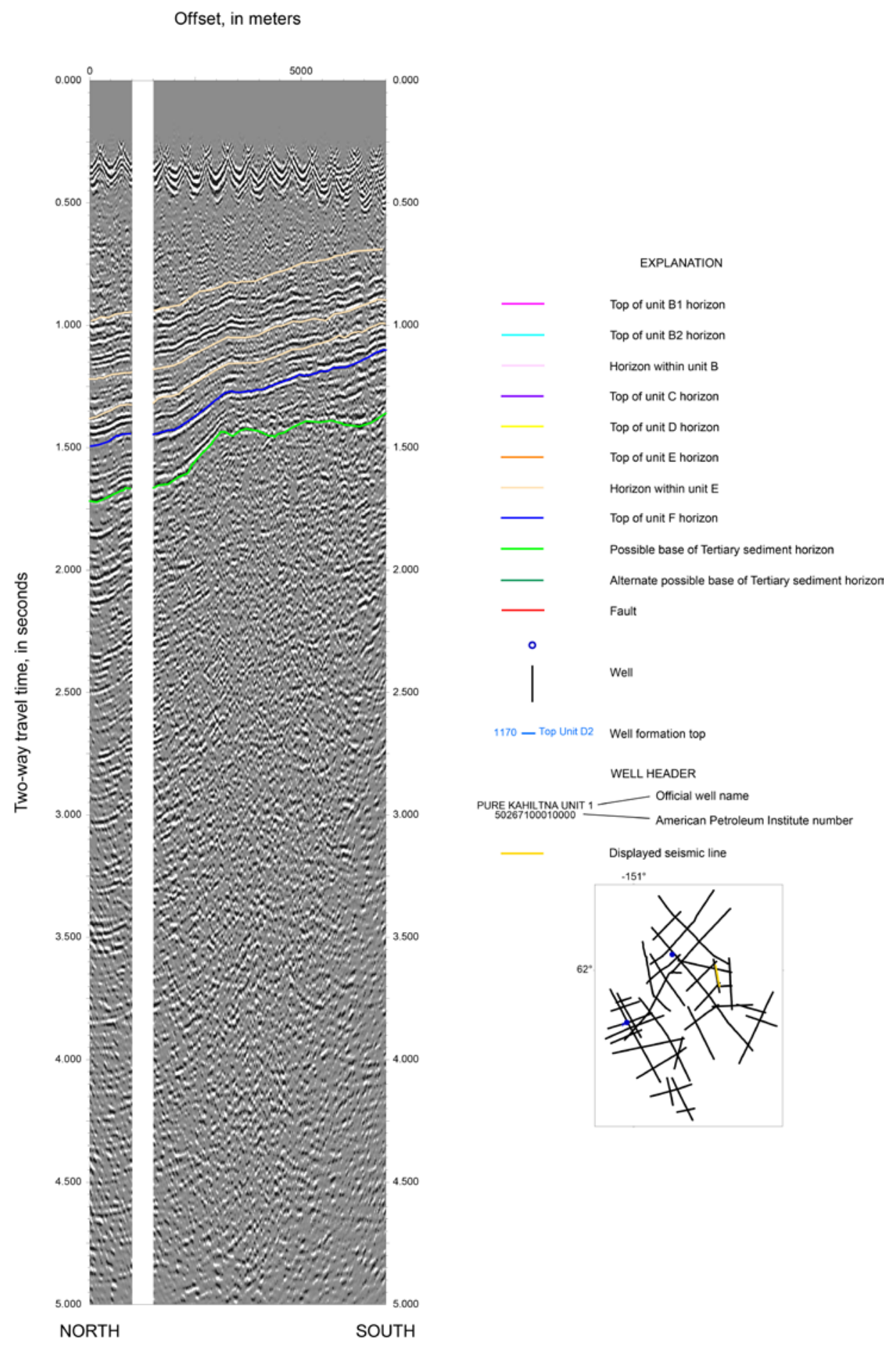

Figure 45. Seismic section 45 with interpretation. The horizontal axis is the offset along the line in meters, and the vertical axis is two-way travel time in seconds. Peaks (positive amplitudes) are black in the seismic section, while troughs (negative amplitudes) are white. The horizons shown correspond to units identified by Stanley and others $(2013,2014)$. Due to the intermittent low signal of the top unit $E$ horizon, additional horizons within unit $\mathrm{E}$ are also shown. (Click here to open full-size, high-resolution image.) 


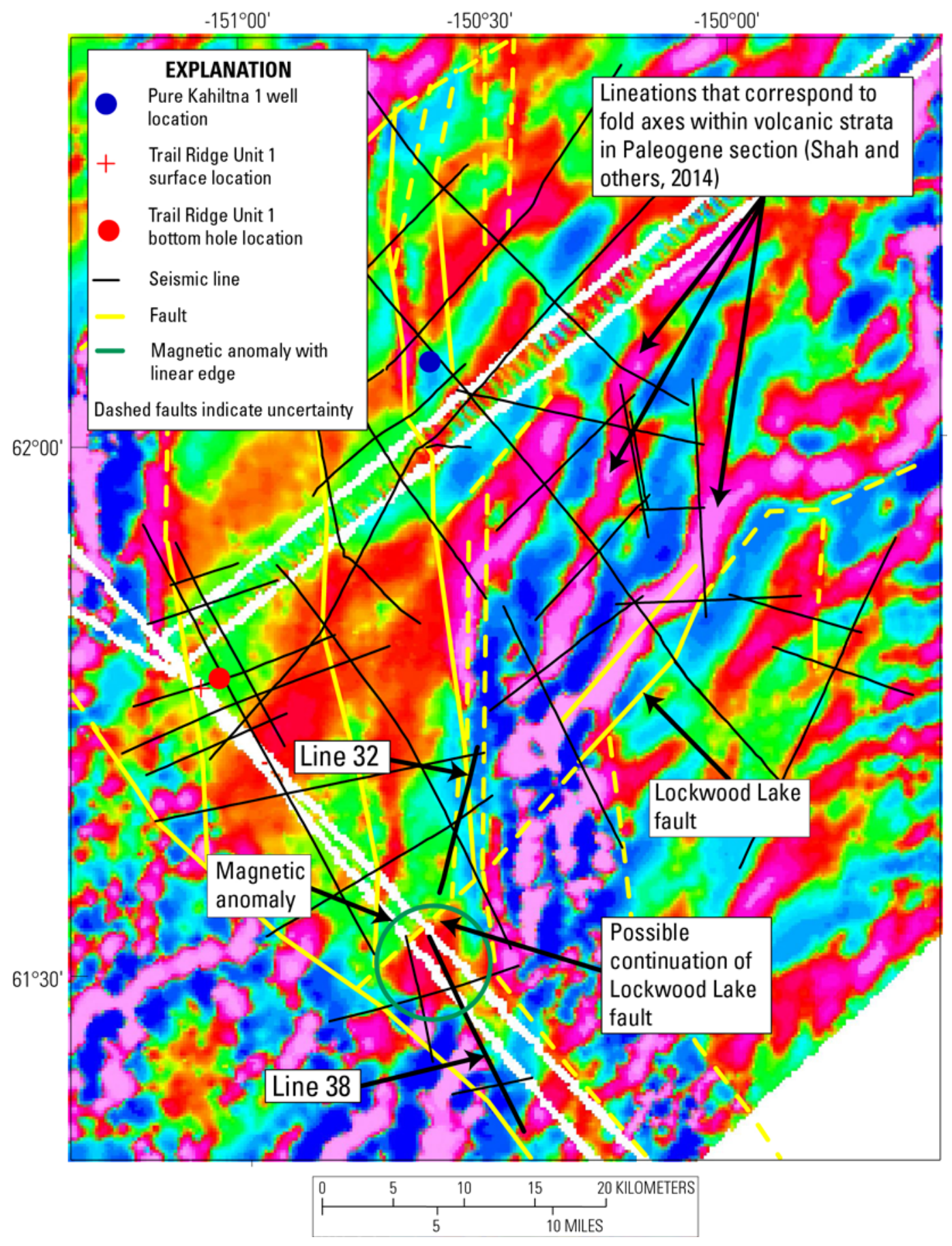

Figure 46. Map showing the filtered aeromagnetic data within the seismic data coverage area. The current fault model, based on the seismic interpretation, is overlain on the filtered magnetic data. The twodimensional seismic lines are shown in black. 


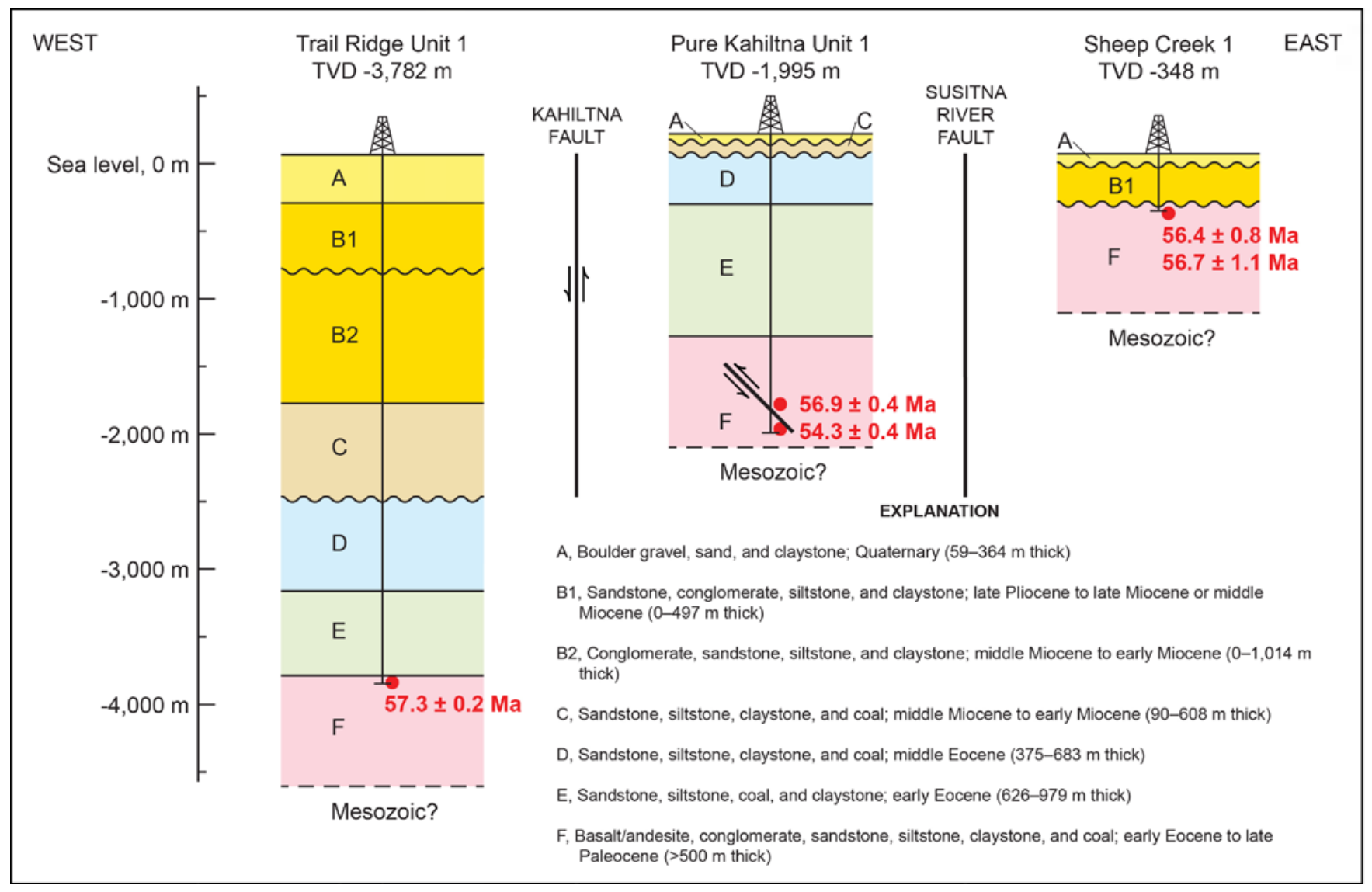

Figure 47. Well correlation of the Trail Ridge Unit 1, Pure Kahiltna Unit 1, and Sheep Creek 1 exploratory wells from Stanley and others (2014). The ages shown are based on palynomorphs and five ${ }^{40} \mathrm{Ar} / 39 \mathrm{Ar}$ step-heating ages on whole-rock samples (Stanley and others, 2014). The stratigraphic units shown were the basis for the horizons picked on the seismic sections. (m, meters; Ma, million years ago). 